\title{
Federal Habeas Relief and the New Tolerance for “Reasonably Erroneous" Applications of Federal Law
}

\author{
TODD E. PETTYS*
}

\begin{abstract}
In Williams v. Taylor and Ramdass v. Angelone, the United States Supreme Court confronted one of the core provisions of the Antiterrorism and Effective Death Penalty Act of 1996 and confirmed what some had hoped and others had feared: A federal court may no longer grant habeas relief merely because it concludes that a state court erroneously applied federal law when it rejected a state prisoner's federal constitutional claim. Instead, a federal court must deny habeas relief to a state prisoner whose federal constitutional rights have been violated and whose requests for relief have been erroneously denied by a state court, so long as the state court's erroneous application of law to fact was objectively reasonable. It is not clear, however, how courts should distinguish between reasonably and unreasonably erroneous applications of federal law.
\end{abstract}

After briefly describing the evolution of the federal habeas standard of review for mixed questions of law and fact, this article points out the ways in which several well-known standards of review fail to illuminate the manner in which courts are to apply the new "unreasonably erroneous" standard. The article then discusses the standard's implicit rejection of two theories of adjudication-deterministic formalism and indeterministic skepticism; examines the contributions of conventionalism; and illustrates the difficulties one faces when trying to frame a theory of adjudication that will enable federal courts to apply the "unreasonably erroneous" standard in a persuasively principled manner in all cases. Finally, the article proposes three analytic touchstones that, in the absence of an overarching theory of adjudication, can help federal courts determine the likelihood that state courts' rulings should be deemed objectively unreasonable.

"[A] federal habeas court may not issue the writ simply because that court concludes in its independent judgment that the relevant state-court decision applied clearly established federal law erroneously or incorrectly. Rather, that application must also be unreasonable."1

\section{INTRODUCTION}

In a pair of rulings handed down in the spring of 2000, the United States

* Associate Professor of Law, University of Iowa College of Law. Many thanks to David Baldus, Randy Bezanson, Catherine Grosso, Ken Kress, and Jerry Wetlaufer for reading and commenting upon earlier drafts of this article.

'Williams v. Taylor, 529 U.S. 362, 411 (2000) (emphasis added). 
Supreme Court finally had occasion to interpret 28 U.S.C. $\$ 2254(d)$, one of the core provisions of the Antiterrorism and Effective Death Penalty Act of 1996 (AEDPA). ${ }^{2}$ Section 2254(d) states that a federal court cannot grant habeas relief to a state prisoner whose federal claim was "adjudicated on the merits in State court proceedings" unless the state court's disposition of that claim "was contrary to, or involved an unreasonable application of, clearly established Federal law, as determined by the Supreme Court of the United States." In Williams v. Taylor and Ramdass $v$. Angelone, the Court determined that $\S 2254$ (d)'s "unreasonable application" clause jettisons more than half a century's worth of habeas jurisprudence relating to state courts' applications of federal law to fact. A federal court may no longer grant habeas relief merely because it concludes that a state court erroneously applied federal law when it rejected a prisoner's claim. Instead, a federal court must allow a state to imprison or execute a habeas petitioner whose federal constitutional rights have been violated, so long as the state court's erroneous application of law to fact was objectively reasonable. ${ }^{6}$ The resulting habeas landscape has been described as "an intellectual disaster area,"7 and the lower federal courts have conceded that they are unsure how to distinguish between reasonably and unreasonably erroneous applications of federal law. As

${ }^{2}$ See Antiterrorism and Effective Death Penalty Act of 1996, Pub. L. No. 104-132, $\S 104(3), 110$ Stat. 1214, 1219 (1996) (codified at 28 U.S.C. § 2254(d) (Supp. II 1996)).

${ }^{3} 28$ U.S.C. $\S 2254(d)$; see also id. (authorizing habeas relief, in the alternative, if the state court's ruling rested upon "an unreasonable determination of the facts in light of the evidence presented in the State court proceeding").

${ }^{4} 529$ U.S. 362 (2000); see infra notes 95-1 18 and accompanying text.

${ }_{5}^{5} 50$ U.S. 156 (2000); see infra notes $119-35$ and accompanying text.

${ }^{6}$ See Ramdass, 530 U.S. at 166 (plurality opinion) (stating that a federal court may grant habeas relief if, "under clearly established federal law, the state court was unreasonable in refusing to extend the governing legal principle to a context in which the principle should have controlled"); Williams, 529 U.S. at 407-08 (holding that a state court's application of federal law is unreasonable if the state court "correctly identifies the governing legal rule but applies it unreasonably to the facts of a particular prisoner's case").

${ }^{7}$ See Larry W. Yackle, The Figure in the Carpet, 78 TEx. L. REV. 1731, 1756 (2000) [hereinafter Yackle, Figure]; see also Brian M. Hoffstadt, How Congress Might Redesign a Leaner, Cleaner Writ of Habeas Corpus, 49 DUKE L.J. 947, 1033-34 (2000) ("[I]t seems wrong to require federal courts to stand idly by when a state court interprets or applies... constitutional rights in an incorrect, but not unreasonable, manner.") (citation omitted).

${ }^{8}$ The United States Court of Appeals for the Ninth Circuit recently observed:

Although the [Williams] Court stated that "unreasonable" is a "common term in the legal world and, accordingly, federal judges are familiar with its meaning," it pointed to no particular body of law as a suitable model. While it is true that determinations of reasonableness are common in the law, such determinations rarely involve a judgment as to the reasonableness of a particular piece of legal reasoning. On the contrary, federal courts have not ordinarily judged the reasonableness, rather than the correctness, of a 
the United States Court of Appeals for the Second Circuit has lamented, "[t]he Supreme Court has thus far offered little guidance as to the meaning of the term 'unreasonable application,' tautologically instructing federal habeas courts to ask whether the state court's application was objectively unreasonable."

This article seeks to determine how best to make sense of the new "unreasonably erroneous" standard of review. ${ }^{10}$ In Part II, I describe the evolution of the federal habeas standard of review for mixed questions of law and fact, from the Court's adoption of a de novo standard in Brown v. Allen, ${ }^{11}$ to the uncertainty engendered by Teague $v$. Lane $e^{12}$ and Butler v. McKellar, ${ }^{13}$ to the Court's conclusion in Williams and Ramdass that $\S 2254$ (d)'s "unreasonable application" clause authorizes habeas relief only if the state court's application of law to fact was unreasonably erroneous. ${ }^{14}$

In Part III, I examine several well-known standards of review that one might assume are likely to help explain what the Court means when it refers to "unreasonably erroneous" applications of law to fact: "clearly erroneous" review of a district court's factual findings, "abuse of discretion" review of a district

court's applications of federal law.

Van Tran v. Lindsey, 212 F.3d 1143, 1151 (9th Cir.) (quoting Williams, 529 U.S. at 410), cert. denied, 531 U.S. 944 (2000) (citation omitted). The Second Circuit has similarly stated:

Justice O'Connor took some comfort in the fact that "unreasonable" is "a common term in the legal world and, accordingly, federal judges are familiar with its meaning." The difficulty, of course, is that we are familiar with its many meanings in the different contexts in which the word (or its antonym) is used. We have no experience in determining when a state court has made an unreasonable application of constitutional law, as expounded by the Supreme Court.

Francis S. v. Stone, 221 F.3d 100, 109 n. 12 (2d Cir. 2000) (quoting Williams, 529 U.S. at 410) (citation omitted); see also Neal v. Puckett, 239 F.3d 683, 695 (5th Cir.) ("[E]ven after Williams, it is not immediately clear to us whether a federal habeas court looks exclusively to the objective reasonableness of the state court's ultimate conclusion or must also consider the method by which the state court arrives at its conclusion."), reh' $g$ granted, 264 F.3d 1149 (5th Cir. 2001).

${ }^{9}$ Lainfiesta v. Artuz, 253 F.3d 151, 155 (2d Cir. 2001) (citing Williams, 529 U.S. at 409).

${ }^{10}$ As Larry Yackle has pointed out, federal habeas courts do not formally "review" state courts' rulings in the appellate sense of that term, and so it might appear misleading to speak of a standard of review in this context. See Yackle, Figure, supra note 7, at 1749 n.108. But, as Professor Yackle acknowledges, "federal habeas has an undeniable appellate flavor." Id. As interpreted in Williams and Ramdass, $\S 2254$ (d) plainly calls upon the federal courts to review state courts' rulings for unreasonable error.

11344 U.S. 443 (1953); see infra notes 56-62 and accompanying text.

12489 U.S. 288 (1989); see infra notes 63-71 and accompanying text.

${ }^{13} 494$ U.S. 407 (1990); see infra note 72 and accompanying text.

${ }^{14}$ See infra notes 88-133 and accompanying text.

${ }^{15}$ See infra notes $141-65$ and accompanying text. 
court's rulings on trial-related matters, ${ }^{16}$ the standard applied when reviewing a district court's imposition of Rule 11 sanctions, ${ }^{17}$ and the standard applied when reviewing an agency's interpretation of an ambiguous statute. ${ }^{18}$ With respect to each, I conclude that comparisons are apt in certain respects but ultimately shed insufficient light on the means by which federal habeas courts are to distinguish between reasonable and unreasonable errors.

In Part IV, I argue that the "unreasonably erroneous" standard is especially problematic because the courts do not have at their disposal a satisfactory theory of adjudication. ${ }^{19}$ After noting $\$ 2254(\mathrm{~d})$ 's implicit rejection of both the deterministic objectivism of formalism and the indeterministic subjectivism of radical skepticism, I consider the analytic utility of conventionalism, a theory of adjudication that, like $\S 2254$ (d), seeks a middle ground between those two extremes. ${ }^{20} \mathrm{I}$ argue that conventionalism will prove useful to federal habeas courts, but fails to provide sufficient guidance in hard cases. My overarching purpose, however, is not simply to point out the normative weaknesses of conventionalism, but rather to examine the difficulties that any theory of adjudication must confront if it is to help the federal courts apply the "unreasonably erroneous" standard.

Recognizing that, with or without a satisfactory theory of adjudication, the federal courts must now apply the "unreasonably erroneous" standard in thousands of cases across the country, in Part V I propose three analytic touchstones that can help those courts determine whether state courts' erroneous rulings should be deemed unreasonable. Specifically, I propose that a federal habeas court ask whether the governing legal directive is most like a rule or a standard, ${ }^{21}$ whether a lower state court was best positioned to resolve the issue and, if so, whether that lower state court found the applicant's claim meritorious; ${ }^{22}$ and whether the federal court believes the applicant has proved his or her claim by a narrow or a wide margin. ${ }^{23}$ These inquiries are not intended to serve as a substitute for a theory of adjudication, nor are they intended to enable all reasonable jurists to agree on the proper outcome in any given case, nor do they succeed in resolving all analytic difficulties created by the new standard. Rather, they are intended to suggest the kinds of tools a court might profitably employ when attempting to execute § 2254(d)'s remarkably difficult charge.

To understand the importance of these issues to the federal habeas enterprise,

\footnotetext{
${ }^{16}$ See infra notes $166-85$ and accompanying text.

${ }^{17}$ See infra notes $186-96$ and accompanying text.

${ }^{18}$ See infra notes 197-209 and accompanying text.

${ }^{19}$ See infra notes $210-84$ and accompanying text.

${ }^{20}$ See infra notes $233-84$ and accompanying text.

${ }^{21}$ See infra notes $287-305$ and accompanying text.

${ }^{22}$ See infra notes 306-15 and accompanying text.

${ }^{23}$ See infra notes 316-19 and accompanying text.
} 
it is necessary to focus briefly on a fundamental distinction. As the phrase itself suggests, the "unreasonable application" clause of $\S 2254$ (d) primarily concerns mixed questions of law and fact. ${ }^{24}$ Distinguishing between pure questions of fact, pure questions of law, and mixed questions of law and fact is a famously troublesome task. ${ }^{25}$ The Court has acknowledged that it "has not charted an entirely clear course in this area," 26 that the methodology for identifying mixed questions "has been, to say the least, elusive,"27 and that the law-fact distinction is sometimes "slippery" 28 and "vexing." 29 Prior to AEDPA's enactment, however,

${ }^{24}$ See Williams v. Taylor, 529 U.S. 362,406 (2000) (stating that "a run-of-the-mill statecourt decision applying the correct legal rule from our cases to the facts of a prisoner's case would not fit comfortably within $\S 2254$ (d)(1)'s 'contrary to' clause," and that such cases should instead ordinarily be reviewed under the statute's "unreasonable application" clause). The "unreasonable application" clause does not focus primarily on whether the state court correctly identified the governing legal principle-that is the main province of the statute's "contrary to" provision. See id. at 405 ("A state-court decision will certainly be contrary to our clearly established precedent if the state court applies a rule that contradicts the governing law set forth in our cases."). Nor does the "unreasonable application" clause ask whether the state court reasonably determined the underlying facts - that is the province of $\S 2254$ (d)(2), which authorizes habeas relief if the state court's nuling "was based on an unreasonable determination of the facts." See 28 U.S.C. $\S 2254$ (d)(2) (Supp. II. 1996). Nevertheless, the statute's "contrary to" and "unreasonable application of" clauses do not always strictly correlate with pure questions of law and mixed questions of law and fact, respectively. See Williams, 529 U.S. at 397 (stating that a state court's ruling may be both "contrary to" and an "unreasonable application of" Supreme Court precedent if it rests upon an erroneous view of the law); infra note 129 and accompanying text (discussing Ramdass). I focus in this article on mixed questions, however, because that is plainly the primary domain of the "unreasonable application" clause.

${ }^{25}$ The law-fact distinction has long been the subject of academic critique. See, e.g., LEON GREEN, JUDGE AND JURY 270-71 (1930) (arguing that the terms "law" and "fact" have no broadly acknowledged meaning and that " $[t]$ he man who could succeed in defining them would be a public enemy" because flexibility in those terms is "essential to the science which has to do with the control of men through the power to pass judgment on their conduct"); JAMES B. Thayer, A Preliminary Treatise ON EVIDENCE AT THE COMMON LAW 183-92 (1898) (attempting to distinguish between questions of fact and questions of law); George C. Christie, Judicial Review of Findings of Fact, 87 Nw. U. L. REV. 14, 14 (1992) (stating that neither courts nor commentators have provided a clear and reliable method of distinguishing between "questions of fact, questions of law, and mixed questions of law and fact"); cf. Gary Lawson, Proving the Law, 86 Nw. U. L. REV. 859, 862-63 (1992) ("While the law-fact distinction is sometimes criticized as confusing and unhelpful, there are good reasons for its enduring character: it provides a serviceable, if not indispensable, tool for allocating decisionmaking authority in a complex, layered legal system.").

${ }^{26}$ Miller v. Fenton, 474 U.S. 104, 113 (1985); accord Cooter \& Gell v. Hartmarx Corp., 496 U.S. 384, 401 (1990) ("The Court has long noted the difficulty of distinguishing between legal and factual issues.").

${ }^{27}$ Miller, 474 U.S. at 113.

${ }^{28}$ Thompson v. Keohane, 516 U.S. 99, 110-11 (1995). 
classifying a question as one of fact or as one of both law and fact was critical in federal habeas proceedings, because those two types of questions correlated with strikingly different standards of review. ${ }^{30}$ Federal courts repeatedly stated that they reviewed state courts' resolutions of mixed questions de novo. ${ }^{31}$ State courts' rulings on mere questions of fact, however, were-and still are-rebuttably presumed to be correct. ${ }^{32}$

During the pre-AEDPA era, federal courts relied upon several guideposts when trying to give questions their appropriate labels-guideposts that continue to play important roles in a variety of contexts calling for law-fact distinctions. In the simplest cases, questions of fact have long been understood to be questions concerning "historical facts: facts 'in' the sense of a recital of external events and the credibility of their narrators." ${ }^{33}$ Mixed questions of law and fact, on the other hand, are questions that "require the application of a legal standard to the

${ }^{29}$ Pullman-Standard v. Swint, 456 U.S. 273, 288 (1982); see also id. (stating that the Court does not know of any "rule or principle that will unerringly distinguish a factual finding from a legal conclusion").

${ }^{30}$ See Steven A. Childress \& Martha S. Davis, Federal Standards OF ReVIEW $\S 7.05$, at 7-32 (3d ed. 1999) ("The law-fact distinction, joined by the pesky but realistic hybrid mixed question, is a difficult concept but often is seen as decisive on appeal."); Martin B. Louis, Allocating Adjudicative Decision Making Authority Between the Trial and Appellate Levels: A Unified View of the Scope of Review, the Judge/Jury Question, and Procedural Discretion, 64 N.C. L. REV. 993, 997 (1986) ("Scope of review ... is the principal means by which adjudicative decisional power and responsibility are divided between the trial and appellate levels.").

${ }^{31}$ See, e.g., Hatch v. Oklahoma, 58 F.3d 1447, 1453 (10th Cir. 1995), cert. denied, 577 U.S. 1235 (1996); Tumer v. Williams, 35 F.3d 872, 886 n.14 (4th Cir. 1994), cert. denied sub nom. Turner v. Jabe, 514 U.S. 1017 (1995); Givens v. Green, 12 F.3d 1041, 1043 (11 th Cir. 1994). In rare instances, the federal courts have held that a state court's ruling on a particular mixed question should be reviewed under a deferential standard. See infra note 39 and accompanying text. Similarly, the federal appellate courts have sometimes held that they will review federal district courts' applications of law to fact merely for clear error. See infra note 153 and accompanying text.

${ }^{32}$ Prior to AEDPA's enactment, state courts' factual findings were presumed to be correct, unless at least one of eight separate statutory exceptions applied. See 28 U.S.C. $\S 2254$ (d) (1994), amended by 28 U.S.C. § 2254(e) (Supp. II 1996). In 1996, Congress amended the statute, providing that state courts' factual findings must be presumed to be correct unless the habeas applicant rebuts that presumption "by clear and convincing evidence." Antiterrorism and Effective Death Penalty Act of 1996, Pub. L. No. 104-132, § 104(4), 110 Stat. 1214, 1219 (1996) (codified at 28 U.S.C. § 2254(e)(1)).

${ }_{33}^{33}$ Townsend v. Sain, 372 U.S. 293, 309 n.6 (1963) (quoting Brown v. Allen, 344 U.S. 443, 506 (1953) (Frankfurter, J.)); see, e.g., Pullman-Standard, 456 U.S. at 288 ("Treating issues of intent as factual matters for the trier of fact is commonplace."); $c f$. THAYER, supra note 25, at 191 (stating that questions of fact for the jury usually concern "things, events, actions, conditions, as happening, existing, really taking placẹ"). 
historical-fact determinations." 34

As Henry Monaghan explained, ${ }^{35}$ however, and as the Court confirmed in Miller $v$. Fenton, ${ }^{36}$ the label applied to a question does not always reflect an analysis merely of the nature of the question itself. ${ }^{37}$ Rather, a question's label sometimes reflects a judgment about who is best situated to resolve the given issue. If "one judicial actor is better positioned than another to decide the issue in question," then the question should be given the label that corresponds to the standard of review that will give the well-positioned judicial actor primary responsibility for resolving the matter. ${ }^{38}$ If the question turns principally on an assessment of witnesses' credibility, for example, the appellate courts probably should classify it as a question of fact warranting deferential review-even if resolving the question does necessitate applying a legal standard-because trial courts usually are best positioned to make those credibility assessments. ${ }^{39}$ If a

${ }^{34}$ Townsend, 372 U.S. at 309 n.6 (1963); see also DUNCAN KENNEDY, A CRITIQUE OF ADJUDICATION 61 (1997) ("It is often roughly accurate to distinguish between a rule and its application, meaning by 'application' the decision whether the factual predicates in the rule that trigger the rule's sanction actually occurred."); Louis, supra note 30, at 1002 ("The process of law application deals with those intermediate adjudicative determinations that combine elements of fact and law and are variously known as ultimate facts, applications of law to fact, or mixed questions of fact and law.").

${ }^{35}$ See Henry P. Monaghan, Constitutional Fact Review, 85 COLUM. L. REV. 229, 237 (1985).

${ }^{36}$ See 474 U.S. 104, 113-14 (1985) (citing Monaghan, supra note 35).

${ }^{37}$ See id.; see also CHILDRESS \& DAVIS, supra note $30, \S 2.13$ (discussing alternative methods of distinguishing between questions of law and fact); KENNETH C. DAVIS, ADMINISTRATIVE LAW TEXT $\S 30.02$ (1959) (distinguishing the "analytical" and "functional" methods of identifying questions of law and fact). But see Chnistie, supra note 25, at 27-31 (arguing that Monaghan wrongly assumes it is possible to distinguish sharply between norm elaboration and norm application).

${ }^{38}$ Miller, 474 U.S. at 114; see also United States v. McConney, 728 F.2d 1195, 1202 (9th Cir.) (en banc) (stating that when determining whether an issue presents a question of fact or a mixed question of law and fact, "the pivotal question is do the concerns of judicial administration favor the district court or do they favor the appellate court"), cert. denied, 469 U.S. 824 (1984); James S. Liebman, Apocalypse Next Time?: The Anachronistic Attack on Habeas Corpus/Direct Review Parity, 92 ColuM. L. REv. 1997, 2000-01 n.12 (1992) (stating that the Court's "categorization of some law-application questions as matters of 'fact' and not 'mixed questions' has the effect of forgoing independent review, apparently based on the difficulty or undesirability of additional judicial norm elaboration").

${ }^{39}$ Miller, 474 U.S. at 114; see, e.g., Wainwright v. Witt, 469 U.S. 412,429 (1985) (holding that, although a state trial court applies a legal standard when determining whether a prospective juror should be dismissed for cause because her opposition to the death penalty might prevent her from impartially applying the law, this determination is entitled to a presumption of correctness because the trial court's "predominant function in determining juror bias involves credibility findings whose basis cannot be easily discerned from an appellate record"); Patton v. Yount, 467 U.S. 1025, 1038 (1984) (holding that a state court's 
principle of law, on the other hand, "can be given meaning only through its application to the particular circumstances of a case," the courts probably should classify questions implicating that principle as questions on which no deference to the state or lower courts is due. ${ }^{40}$

Using such standards to guide them prior to AEDPA's enactment, federal habeas courts determined that nearly all of the questions they routinely confront are mixed questions of law and fact, subject to de novo review. ${ }^{41}$ These questions include, among a host of others, ${ }^{42}$ whether a person's confession to a crime was voluntarily given, ${ }^{43}$ whether a person was "in custody" for purposes of Miranda $v$. Arizona ${ }^{44}$ at the time she was interrogated, ${ }^{45}$ whether a person voluntarily waived her Miranda rights, ${ }^{46}$ whether pre-trial identification procedures were unconstitutionally suggestive, ${ }^{47}$ whether a person received effective assistance of counsel, ${ }^{48}$ whether the admission of hearsay statements violated a person's right to confront adverse witnesses, ${ }^{49}$ whether an attorney acted under a conflict of

determination of juror bias centers upon questions of credibility, and so is entitled to deference); see also Thompson v. Keohane, 516 U.S. 99, 111 (1995) (discussing this line of cases).

Conversely, the Court has indicated that predominantly factual questions should sometimes be subjected to a more stringent standard of review, when the issues raised are especially important. See Bose Corp. v. Consumers Union of United States, Inc., 466 U.S. 485, $501 \mathrm{n} .17$ (1984) ("Regarding certain largely factual questions in some areas of the law, the stakes-in terms of impact on future cases and future conduct-are too great to entrust them finally to the judgment of the trier of fact.").

${ }^{40}$ Miller, 474 U.S. at 114; see, e.g., Bose Corp., 466 U.S. at 498-99, 511 (holding that the determination of whether a person published a false statement with "actual malice" is not a pure question of fact subject to review only for clear error, but is instead a mixed question of law and fact subject to independent review).

${ }^{41}$ Cf. Williams v. Taylor, 529 U.S. 362, 384 (2000) (opinion of Stevens, J.) ("Most constitutional questions that arise in habeas corpus proceedings ... require the federal judge to apply a rule of law to a set of facts ....").

${ }^{42}$ See 2 James S. LIEBMAN \& Randy Hertz, Federal Habeas Corpus Practice AND PROCEDURE $§ 25.5$ (3d ed. 1998) (providing numerous examples).

${ }^{43}$ See Miller, 474 U.S. at 112 . Whether a person voluntarily entered her guilty plea, however, is a question of law. See Marshall v. Lonberger, 459 U.S. 422, 431 (1983).

44384 U.S. 436, 467 (1966) (holding that, under the Fifth Amendment, statements made by persons interrogated while in police custody are inadmissible unless those persons were first advised of certain rights).

${ }^{45}$ See Thompson v. Keohane, 516 U.S. 99, 107-16 (1995). The Thompson Court applied a two-step analysis, prescribing deference to the state court's findings concerning 'the circumstances surrounding the interrogation," but de novo review of the legal conclusions to be drawn from those historical facts. Id. at 112-13.

${ }^{46}$ See Ahmad v. Redman, 782 F.2d 409, 413 (3d Cir.), cert. denied, 479 U.S. 831 (1986).

${ }^{47}$ See Sumner v. Mata, 455 U.S. 591, 597 (1982); Montgomery v. Greer, 956 F.2d 677, 681 (7th Cir.), cert. denied, 506 U.S. 972 (1992).

${ }_{48}^{48}$ See Strickland v. Washington, 466 U.S. 668, 698 (1984).

${ }^{49}$ See Haggins v. Warden, 715 F.2d 1050, 1055 (6th Cir. 1983), cert. denied, 464 U.S. 
interest by representing multiple defendants, ${ }^{50}$ whether a prosecutor was required to disclose potentially exculpatory evidence to a defendant, ${ }^{51}$ and whether the evidence presented at trial was sufficient to support a conviction. ${ }^{52}$

As construed in Williams and Ramdass, $\S 2254(\mathrm{~d})$ importantly changes the standard of review for each and every one of those questions. Indeed, the distinction between questions of fact and mixed questions of law and fact is not nearly as portentous in federal habeas proceedings as it once was. ${ }^{53}$ The distinction is not superfluous, because mixed questions and questions of fact still receive formally different analyses on federal habeas review. ${ }^{54}$ Yet the thrust of those analyses is now the same: A federal court will not disturb a state court's reasonable ruling, even if the federal court would have decided the issue differently on de novo review. ${ }^{55}$ How did we arrive at a point at which federal courts deny habeas relief to state prisoners whose federal constitutional rights have been violated, so long as the state courts' erroneous rejection of those prisoners' claims was objectively reasonable? And how should federal courts distinguish between reasonably and unreasonably erroneous applications of federal law? Those are the subjects of this article.

1071 (1984).

${ }^{\text {so }}$ See Cuyler v. Sullivan, 446 U.S. 335, 341 (1980).

${ }^{51}$ See Banks v. Reynolds, 54 F.3d 1508, 1516 (10th Cir. 1995); see also Brady v. Maryland, 373 U.S. 83, 87 (1963) (holding that "the suppression by the prosecution of evidence favorable to an accused upon request violates due process where the evidence is material either to guilt or to punishment, irrespective of the good faith or bad faith of the prosecution").

${ }^{52}$ See Maes v. Thomas, 46 F.3d 979, 988 (10th Cir.), cert. denied, 514 U.S. 1115 (1995); see also Jackson v. Virginia, 443 U.S. 307, 319 (1979) (holding that a person's due process rights are violated if he is convicted and the evidence presented at trial, viewed in the light most favorable to the prosecution, was not sufficient to enable a rational juror to conclude that the person's guilt had been proven beyond a reasonable doubt).

${ }^{53}$ Indeed, the vitality of Miller's functional analysis for distinguishing between mixed questions and questions of fact in habeas proceedings is very much in doubt, because a key presumption of Miller's analysis-that mixed questions and questions of fact are subject to non-deferential and deferential review, respectively-is no longer true. See supra notes 36-40 and accompanying text (describing Miller's functional analysis).

${ }^{54}$ Compare supra note 32 (describing AEDPA's standard of review for pure questions of fact), with infra notes 95-135 and accompanying text (discussing AEDPA's "unreasonably erroneous" standard of review for mixed questions).

${ }^{55}$ This assumes, of course, that a ruling that is "contrary to" Supreme Court precedent within the meaning of $\S 2254(\mathrm{~d})$ cannot be deemed reasonable. 


\section{THE EMERGENCE OF THE "UNREASONABLY ERRONEOUS" STANDARD OF REVIEW}

\section{A. From De Novo to Doubts}

Beginning at least as early as the Supreme Court's landmark ruling in Brown v. Allen, ${ }^{56}$ federal habeas courts reviewed state courts' applications of federal law to fact de novo. ${ }^{57}$ In Brown, the Court emphasized that, while federal courts ordinarily should defer to state courts' findings of fact, they should independently review state courts' rulings on pure questions of law and on mixed questions of law and fact. ${ }^{58}$ With respect to mixed questions, Justice Frankfurter explained:

Where the ascertainment of the historical facts does not dispose of the claim but calls for interpretation of the legal significance of such facts, the District Judge must exercise his own judgment on this blend of facts and their legal values. Thus, so-called mixed questions or the application of constitutional principles to the facts as found leave the duty of adjudication with the federal judge.

For instance, the question whether established primary facts underlying a confession prove that the confession was coerced or voluntary cannot rest on the State decision. ... Although there is no need for the federal judge, if he could, to shut his eyes to the State consideration of such issues, no binding weight is to be attached to the State determination. ${ }^{59}$

In a long line of habeas cases culminating in Miller $v$. Fenton, ${ }^{60}$ the Court

${ }^{56} 344$ U.S. 443 (1953). Two majority opinions were written in Brown-one by Justice Reed and one by Justice Frankfurter. See id. at 446-87 (Reed, J.); id. at 488-513 (Frankfurter, J.). For a concise discussion of Brown's two majority opinions, see Liebman, supra note 38, at 2019-29.

${ }^{57}$ See Liebman, supra note 38, at 2028-29 ("Whatever may have come before 1953, as of that year it was the firm conviction of a unanimous Court that all constitutional claims were cognizable in habeas corpus and that each claim was due de novo federal review ....").

${ }^{58}$ Brown, 344 U.S. at 458 (Reed, J.). The Court stated:

[W] here there is material conflict of fact ..., the District Court may properly depend upon the state's resolution of the issue. In other circumstances[,] the state adjudication carries the weight that federal practice gives to the conclusion of a court of last resort of another jurisdiction on federal constitutional issues. It is not res judicata.

Id. But see Wright v. West, 505 U.S. 277, 287-89 (1992) (plurality opinion) (conceding that Brown rejected "the principle of absolute deference" to state courts on mixed questions, but contending that Brown did not precisely articulate the appropriate standard of review). For a discussion of the Justices' several opinions in West, see infra notes 73-86 and accompanying text.

\footnotetext{
${ }^{59}$ Brown, 344 U.S. at 507-08 (Frankfurter, J.) (emphasis added).

${ }^{60} 474$ U.S. 104 (1985).
} 
expressly or implicitly reiterated that federal courts must apply a de novo standard of review when examining state courts' applications of law to fact. ${ }^{61}$ In Miller, the Court confronted the mixed question that Justice Frankfurter had posited in Brown: the voluntariness of a confession. The Court held that, when a habeas applicant claims that the state trial court erred by refusing to suppress her involuntary confession, the federal court must determine the merits of that claim de novo. ${ }^{62}$

Seven years later, in Wright $v$. West, ${ }^{63}$ a fractured Court found itself debating whether federal courts should instead grant some measure of deference to state courts' resolutions of mixed questions. What had placed the issue in any doubt? In the eyes of some observers, the logic of the non-retroactivity rule endorsed by a plurality of the Court in Teague v. Lane, ${ }^{64}$ adopted in Penry v. Lynaugh, ${ }^{65}$ and

${ }^{61}$ See West, 505 U.S. at 301-03 (O'Connor, J., concurring in the judgment) (listing twenty-seven cases and stating that "[t]here have been many others"); 2 LIEBMAN \& HERTZ, supra note $42, \S 2.4 \mathrm{~b}$, at $\mathrm{n} .9$ (listing numerous authorities). For examples of the many mixed questions that federal habeas courts reviewed de novo, see supra notes 41-52 and accompanying text.

${ }^{62}$ Miller, 474 U.S. at 112 . The Court had previously indicated that "the 'ultimate constitutional question' of the admissibility of a confession was a 'mixed [question] of fact and law' subject to plenary federal review." Id. (quoting Townsend v. Sain, 372 U.S. 293, 309 \& n.6 (1963)). The Miller Court concluded that deference to a state court's voluntariness determination was indeed inappropriate because that determination has "a uniquely legal dimension," because assessments of credibility and demeanor are not central components of the analysis, and because the federal courts have "traditionally played an important parallel role in protecting the rights at stake when the prosecution secures a conviction through the defendant's own admissions." Id. at 116-18.

${ }^{63}$ 505 U.S. 277 (1992).

${ }^{64} 489$ U.S. 288 (1989). Teague and its now-familiar rule have been the focus of an impressive body of scholarship. See, e.g., Marc M. Arkin, The Prisoner's Dilemma: Life in the Lower Federal Courts After Teague v. Lane, 69 N.C. L. REV. 371 (1991); Markus D. Dubber, Prudence and Substance: How the Supreme Court's New Habeas Retroactivity Doctrine Mirrors and Affects Substantive Constitutional Law, 30 AM. CRIM. L. REV. 1 (1992); Richard H. Fallon, Jr. \& Daniel J. Meltzer, New Law, Non-Retroactivity, and Constitutional Remedies, 104 Harv. L. Rev. 1731 (1991); Stephen M. Feldman, Diagnosing Power: Postmodernism in Legal Scholarship and Judicial Practice (with an Emphasis on the Teague Rule Against New Rules in Habeas Corpus Cases), 88 Nw. U. L. REV. 1046 (1994); Barry Friedman, Habeas and Hubris, 45 VAND. L. REV. 797 (1992); Patrick E. Higginbotham, Notes on Teague, 66 S. CAL. L. REv. 2433 (1993); Linda Meyer, "Nothing We Say Matters": Teague and New Rules, 61 U. CHI. L. REV. 423 (1994); see also Vivian Berger, Justice Delayed or Justice Denied? A Comment on Recent Proposals to Reform Death Penalty Habeas Corpus, 90 COLUM. L. REV. 1665,1703 (1990) (stating that "Teague and its burgeoning progeny amount to the most significant development in habeas doctrine in recent years"). Teague's tremendous significance arose from its tendency both to place significant restraints on one of the primary means by which the Court had recognized new rules of constitutional law and to place a significant new hurdle in the path of many prisoners seeking habeas relief. With respect to the former, see 
clarified in Butler v. McKellar implicitly necessitated a deferential standard of review for mixed questions. ${ }^{67}$ As all habeas practitioners know, Justice O'Connor declared for a plurality in Teague that, absent extraordinary circumstances, ${ }^{68}$ "new constitutional rules of criminal procedure will not be applicable to those cases which have become final before the new rules are announced."69 Teague did not provide detailed guidance on how the federal courts should identify "new rules" of constitutional law. ${ }^{70}$ The plurality simply stated that a federal court announces a new rule "when it breaks new ground or imposes a new obligation on the States or the Federal Government" or when it reaches a result that "was not dictated by precedent existing at the time the defendant's conviction became final." ${ }^{, 71}$ In Butler, decided the following Term, the Court attempted to clarify the Teague analysis, stating that a habeas applicant's claim impermissibly rests upon the recognition of a new rule if, at the time the applicant's conviction became final, the proper resolution of that claim was "susceptible to debate among reasonable minds." non-retroactivity principle tantamount to declaring that federal courts must defer to state courts' reasonably erroneous articulations of federal law? If so, would deference on mixed questions similarly be appropriate?

The Court first addressed the possibility of a relationship between Teague,

Teague, 489 U.S. at 334-37 (Brennan, J., dissenting) (listing numerous examples of new constitutional nules declared by the Court on habeas review).

${ }^{65} 492$ U.S. 302, 314 (1989).

${ }^{66} 494$ U.S. 407, $415(1990)$.

${ }^{67}$ See West, 505 U.S. at 291-94 (plurality opinion); infra notes 73-81 and accompanying text.

${ }^{68}$ The Teague plurality identified two narrow circumstances in which a habeas applicant may claim the benefit of a newly recognized constitutional rule: (1) when the new rule "places 'certain kinds of primary, private individual conduct beyond the power of the criminal lawmaking authority to proscribe"' and (2) when the new rule mandates a procedure that is "'implicit in the concept of ordered liberty" and that, when not implemented, seriously diminishes "the likelihood of an accurate conviction." Teague, 489 U.S. at 311, 313 (plurality opinion) (quoting Mackey v. United States, 401 U.S. 667, 692-93 (1971) (Harlan, J., concurring in the judgment in part and dissenting in part)).

${ }^{69}$ Teague, 489 U.S. at 310 (plurality opinion).

${ }^{70}$ Id. at 301 (plurality opinion) ("It is admittedly often difficult to determine when a case announces a new rule, and we do not attempt to define the spectrum of what may or may not constitute a new rule for retroactivity purposes.").

${ }^{71}$ Id. When an applicant's claim rests upon such a rule, a federal habeas court ordinarily must dismiss the petition. $I d$. at 300 (plurality opinion) ("Retroactivity is properly treated as a threshold question ....").

${ }_{72}$ Butler v. McKellar, 494 U.S. 407, 415 (1990) (emphasis added); accord Sawyer v. Smith, 497 U.S. 227, 234 (1990) ("The principle announced in Teague serves to ensure that gradual developments in the law over which reasonable jurists may disagree are not later used to upset the finality of state convictions valid when entered."). 
Butler, and the appropriate standard of review for mixed questions in Wright $\nu$. West. ${ }^{73}$ Frank West challenged the sufficiency of the evidence to support his grand-larceny conviction. The Court asked the parties to address the following question:

In determining whether to grant a petition for a writ of habeas corpus by a person in custody pursuant to the judgment of a state court, should a federal court give deference to the state court's application of law to the specific facts of the petitioner's case or should it review the state court's determination de novo? ${ }^{74}$

After considering the merits of West's petition, the Justices found it unnecessary to decide whether to abandon the de novo standard: Regardless of the standard of review, West's claim failed. ${ }^{75}$ Nevertheless, the Justices took the occasion to express sharply divided views on the question they had posed to the parties. $^{76}$

Justice Thomas, announcing the Court's judgment and joined by Chief Justice Rehnquist and Justice Scalia, argued that Brown had not established the precise standard of review for pure questions of law or for mixed questions of law and fact. Rather, federal courts had simply fallen into the habit of citing Brown for a de novo standard for both types of questions. ${ }^{77}$ Justice Thomas argued that

${ }^{73} 505$ U.S. 277, 291 (1992) (plurality opinion).

${ }^{74}$ Wright v. West, 502 U.S. 1021 (1991) (amending the grant of a writ of certiorari). In his opinion concurring in the judgment in West, Justice Kennedy explained the Court's request:

[My colleagues debate] the reasons that took us to the point where mixed constitutional questions are subject to de novo review in federal habeas corpus proceedings. Whatever the answer to that difficult historical inquiry, all agree that, at least prior to the Court's adoption of the retroactivity analysis of Teague $v$. Lane, ... the matter was settled. It seems that the real issue dividing my colleagues is whether the retroactivity analysis of Teague casts doubt upon the rule of Miller v. Fenton .... Even petitioner State of Virginia and the United States as amicus curiae, both seeking a deferential standard with respect to mixed questions, recognize that this is how the standard of review question arises.

West, 505 U.S. at 306 (Kennedy, J., concurring intthe judgment) (citations omitted).

${ }^{75}$ See West, 505 U.S. at 295 (plurality opinion) ("Whatever the appropriate standard of review, we conclude that there was more than enough evidence to support West's conviction."); id. at 297 (White, J., concurring in the judgment); id. (O'Connor, J., concurring in the judgment); id. at 310 (Kennedy, J., concurring in the judgment); id. (Souter, J., concurring in the judgment); see also Jackson v. Virginia, 443 U.S. 307, 319 (1979) (holding that, "to guarantee the fundamental protection of due process of law," a reviewing court must overturn a guilty verdict if, "viewing the evidence in the light most favorable to the prosecution," no rational juror "could have found the essential elements of the crime beyond a reasonable doubt").

${ }^{76}$ For a more detailed discussion of the Justices' competing views in West, see Liebman, supra note 38 , at 2010-36.

${ }^{77}$ West, 505 U.S. at 287-89 (plurality opinion); see supra notes 56-62 and accompanying 
Brown actually had mandated only that a federal habeas court

determine whether the state-court adjudication "has resulted in a satisfactory conclusion." We had no occasion [in Brown] to explore in detail the question whether a "satisfactory" conclusion was one that the habeas court considered correct, as opposed to merely reasonable, because we concluded that the constitutional claims advanced in Brown itself would fail even if the state courts' rejection of them were considered de novo. ${ }^{78}$

Justice Thomas contended that Teague and Butler had cast doubt on the continued vitality of de novo review, "at least with respect to pure legal questions." "If a "new rule" for retroactivity purposes is a rule "susceptible to debate among reasonable minds," Justice Thomas reasoned, then a federal habeas court must defer to a state court's reasonable articulation of the governing federal law, even if that articulation differs from the one the federal court would provide. $^{80}$ Justice Thomas then noted-but stopped short of expressly endorsing - the State of Virginia's argument that, if Teague requires deference to state courts' reasonable articulations of federal law, and if longstanding authority requires deference to state courts' reasonable findings of fact, then it makes little sense to apply anything other than a deferential standard of review to state courts' applications of law to fact. ${ }^{81}$

Justice O'Connor, joined by Justice Blackmun and Justice Stevens, argued that Justice Thomas had "understate[d] the certainty with which Brown v. Allen rejected a deferential standard of review of issues of law" ${ }^{182}$ and had ignored numerous cases in which the Court emphasized that mixed questions of law and fact were reviewed de novo. ${ }^{83}$ Justice O'Connor also took issue with Justice Thomas's characterization of the plurality opinion she had written in Teague. In Justice O'Connor's view, Teague had simply adopted a choice-of-law rule for federal habeas proceedings, rather than establish a deferential standard of review for questions of law. ${ }^{84}$ Butler's "susceptible to debate among reasonable minds" formulation of the Teague analysis mandates an objective inquiry, she argued,

text (discussing Brown and Miller).

${ }^{78}$ West, 505 U.S. at 287 (plurality opinion) (quoting Brown v. Allen, 344 U.S. 443, 463 (1953)) (citation omitted). But cf. Liebman, supra note 38, at 2028 (stating that, prior to Justice Thomas's opinion in West, Brown had universally been regarded as establishing a de novo standard of review and that "Justice Thomas is the only observer to miss Brown's de novo review requirement").

${ }^{79}$ West, 505 U.S. at 291 (plurality opinion).

${ }^{80} \mathrm{Id}$.

${ }^{81}$ Id. at 294 (plurality opinion).

${ }^{82}$ Id. at 300 (O'Connor, J., concurring in the judgment).

${ }^{83} \mathrm{Id}$. at 301-03 (O'Connor, J., concurring in the judgment).

${ }^{84} \mathrm{Id}$. at 303-04 (O'Connor, J., concurring in the judgment) 
requiring independent, non-deferential scrutiny by a federal court. ${ }^{85}$ Justice Kennedy expressed comparable views in a separate opinion. ${ }^{86}$

\section{B. From AEDPA to Williams and Ramdass}

In 1996, before the Court had an opportunity expressly to resolve the issues debated in $W_{e s t}{ }^{87}$ Congress changed the habeas landscape by enacting AEDPA. ${ }^{88}$ At the core of that legislation lies provisions codified at 28 U.S.C.

${ }^{85}$ Id. at 304 (O'Connor, J., concurring in the judgment) (intemal quotation omitted). Thus, when determining whether a rule is "new" for Teague purposes, a federal court

must make an independent evaluation of the precedent existing at the time the state conviction became final in order to determine whether the case under consideration is meaningfully distinguishable. Teague does not direct the federal courts to spend less time or effort scrutinizing the existing federal law, on the ground that they can assume the state courts interpreted it properly.

Id. at 305 (O'Connor, J., concurring in the judgment). Justice O'Connor emphasized that, while a federal court may pay close attention to a state court's ruling when conducting de novo review-just as it may pay close attention to any carefully reasoned authority- "this does not mean that ... federal courts must presume the correctness of a state court's legal conclusions on habeas.... We have always held that federal courts, even on habeas, have an independent obligation to say what the law is." Id.

${ }^{86}$ Concurring in the judgment, Justice Kennedy asserted that "neither the purpose for which Teague was adopted nor the necessary means for implementing its holding creates any real conflict with the requirement of de nowo review of mixed questions." Id. at 306-07 (Kennedy, J., concurring in the judgment). A rule of deference, Justice Kennedy reasoned, would require that a federal habeas court let stand a state court's ruling on a close legal question, on the theory that the federal court is in no better position to determine the correct ruling. Id. at 308 (Kennedy, J., concurring in the judgment). That rationale-which underlies federal habeas courts' deference to state courts' findings of fact-is not the rationale that underlies Teague. Teague's purpose, Justice Kennedy wrote, is to avoid undermining convictions by changing the rules under which prosecutors secured those convictions. Rather than establish a nule of deference for close cases, then, Teague employs a "reasonable jurists" standard in order to avoid upsetting convictions with rules that were not genuinely dictated by precedent at the time the convictions became final. Id. at 307-08 (Kennedy, J., concurring in the judgment). Justice Souter also concurred in the judgment, noting that he "could not disagree with the majority that sufficient evidence supported West's conviction," id. at 310 (Souter, J., concurring in the judgment), but concluding that the Court should not reach that issue because West was attempting to claim the benefit of a new rule, in violation of Teague. See id. at 310 16 (Souter, J., concurring in the judgment).

${ }^{87}$ See supra notes 73-86 and accompanying text. But cf. Thompson v. Keohane, 516 U.S. $99,112-16$ (1995) (holding that whether a person was in custody at the time of an interrogation is a mixed question of law and fact that merits a federal habeas court's independent review, rather than a factual question warranting deferential review, but refraining from making express reference to the debate in West).

${ }^{88}$ See Antiterrorism and Effective Death Penalty Act of 1996, Pub. L. No. 104-132, 110 


\section{$\S 2254(d):$}

An application for a writ of habeas corpus on behalf of a person in custody pursuant to the judgment of a State court shall not be granted with respect to any claim that was adjudicated on the merits in State court proceedings unless the adjudication of the claim-

(1) resulted in a decision that was contrary to, or involved an unreasonable application of, clearly established Federal law, as determined by the Supreme Court of the United States; or

(2) resulted in a decision that was based on an unreasonable determination of the facts in light of the evidence presented in the State court proceeding. ${ }^{89}$

In the months and years following AEDPA's enactment, courts and scholars debated $\$ 2254$ (d)'s meaning and Congress's power to enact such legislation. ${ }^{90}$ Some concluded that $\S 2254$ (d) preserves federal courts' power independently to articulate principles of federal law, but bars them from granting habeas remedies

Stat. 1214 (1996) (codified at 28 U.S.C. $\$ \S 2244,2253-55,2261-66$ (Supp. II 1996)).

${ }^{89}$ Id. § 104(3) (codified at 28 U.S.C. § 2254(d)).

${ }^{90}$ For a summary of the federal appellate courts' varying interpretations of $\S 2254$ (d) prior to Williams and Ramdass, see Nevers v. Killinger, 169 F.3d 352, 357-62 (6th Cir.), cert. denied, 527 U.S. 1004 (1999). Among academics, § 2254(d) has understandably provoked a significant body of scholarship. See, e.g., Alan K. Chen, Shadow Law: Reasonable Unreasonableness, Habeas Theory, and the Nature of Legal Rules, 2 BUFF. CRIM. L. REV. 535, 539 (1999) (arguing that $\$ 2254$ (d)(1)'s deferential standard of review forces federal habeas courts to "operate in a world where substantive constitutional law lurks in a hazy background"); Evan T. Lee, Section 2254(d) of the New Habeas Statute: An (Opinionated) User's Manual, 51 VAND. L. REV. 103 (1998) (discussing issues relating to the interpretation of § 2254(d)); James S. Liebman \& William F. Ryan, "Some Effectual Power": The Quantity and Quality of Decisionmaking Required of Article III Courts, 98 CoLUM. L. REV. 696, 864-84 (1998) (arguing that Article III forbids an interpretation of $\S 2254$ (d) that would prevent federal habeas courts from independently and non-deferentially reviewing state courts' applications of federal law and granting appropriate relief); Kent S. Scheidegger, Habeas Corpus, Relitigation, and the Legislative Power, 98 COLUM. L. REV. 888 (1998) (arguing that AEDPA constitutionally abolishes the rule of de novo review of mixed questions of law and fact); Mark Tushnet \& Larry Yackle, Symbolic Statutes and Real Laws: The Pathologies of the Antiterrorism and Effective Death Penalty Act and the Prison Litigation Reform Act, 47 DUKE L.J. 1 (1997) (arguing that AEDPA is a symbolic statute and will be interpreted primarily as a codification of already extant law); Larry W. Yackle, A Primer on the New Habeas Corpus Statute, 44 BUFF. L. REV. 381 (1996) [hereinafter Yackle, Primer] (providing a comprehensive overview of AEDPA); Sharad S. Khandelwal, Note, The Path to Habeas Corpus Narrows: Interpreting 28 U.S.C. $\$ 2254(d)(1), 96 \mathrm{MICH}$. L. REV. 434 (1997) (examining varying interpretations of $\S 2254(\mathrm{~d}))$; Note, Rewriting the Great Writ: Standards of Review for Habeas Corpus Under the New 28 U.S.C. \$2254, 110 HARV. L. REV. 1868 (1997) [hereinafter Harvard Note] (arguing that AEDPA changes federal habeas corpus review in many ways). 
when the state courts reasonably (albeit incorrectly) applied federal law to fact. ${ }^{91}$ Others concluded that the statute establishes a deferential standard of review for both pure questions of law and mixed questions of law and fact. ${ }^{92}$ Still others argued that adopting either of the preceding interpretations would deprive the federal courts of the judicial power in violation of Article III, insofar as it would require a federal court to let stand a ruling that it believes is erroneous and that concerns either the interpretation or the application of federal law. ${ }^{93}$ On this last view, $\S 2254(\mathrm{~d})$ was to be understood merely as codifying Teague as a choice-oflaw rule for federal habeas proceedings. ${ }^{94}$

${ }^{91}$ See, e.g., Lindh v. Murphy, 96 F.3d 856, 868-74 (7th Cir. 1996) (en banc), rev'd on other grounds, 521 U.S. 320 (1997); Scheidegger, supra note 90, at 948-60 (arguing that $\$ 2254$ (d)'s "unreasonable application" clause permits a federal habeas court to grant relief only when there is a "fundamental defect" in the state court's application of law to fact, and arguing that such a standard does not unconstitutionally deprive federal courts of the judicial power). With respect to the statute's "unreasonable application" clause in particular, for example, the United States Court of Appeals for the Fifth Circuit held that a federal court cannot grant habeas relief unless the "state court decision is so clearly incorrect that it would not be debatable among reasonable jurists." Drinkard v. Johnson, 97 F.3d 751, 769 (5th Cir. 1996), overruled in part on other grounds by Lindh v. Murphy, 521 U.S. 320 (1997); see also Neelley v. Nagle, 138 F.3d 917, 924 (1 1 th Cir. 1998) (adopting the Drinkard standard); Harvard Note, supra note 90, at 1872-73 (discussing the interpretations adopted by the Fifth and Seventh Circuits in Drinkard and Lindh).

${ }_{92}$ See, e.g., Chen, supra note 90, at 572-73 (concluding that this is "[t]he best (descriptive) interpretation of $\S 2254(\mathrm{~d})$ (1)'s language"); Hoffstadt, supra note 7, at 1032-33 (stating that Congress appears to have adopted the deferential standard of review described by Justice Thomas in West); see also Perez v. Marshall, 946 F. Supp. 1521, 1533 (S.D. Cal. 1996) (concluding that $\$ 2254$ (d) mandates a deferential standard of review for both pure questions of law and mixed questions of law and fact), aff'd, 121 F.3d 716 (9th Cir. 1997).

${ }^{93}$ See, e.g., Liebman \& Ryan, supra note 90, at 864-84 (critiquing the approaches taken by the Fifth, Seventh, and Eleventh Circuits described in note 91 supra); Yackle, Primer, supra note 90, at 383-84 (arguing that $\S 2254$ (d) requires a federal court to take "serious account" of the state court's ruling, but that the statute "establishes no general rule of deference to 'reasonable' state court decisions on questions of federal law or on mixed questions of law and fact" and that a rule of deference would constitute "flagrant interference with the federal judicial function"); $c f .142$ CONG. REC. 7764 (1996) (statement of Sen. Moynihan) ("We are about to enact a statute which would hold that constitutional protections do not exist unless they have been unreasonably violated. ... To require a Federal court to defer to a State court's judgment unless the State court's decision is unreasonably wrong effectively precludes Federal review."); id. at 7792 (statement of Sen. Levin) ("I believe the courts will conclude, as they should, that a constitutional error cannot be reasonable and that if a State court decision is wrong, it must necessarily be unreasonable.").

${ }^{94}$ See, e.g., Tushnet \& Yackle, supra note 90, at 42-46 (conceding that $\$ 2254$ (d) might be interpreted to codify the views discussed by Justice Thomas in West, but arguing that such an interpretation is highly unlikely and that the statute instead should be understood as merely codifying the Teague choice-of-law rule). 
The Court entered the fray in Williams v. Taylor. ${ }^{95}$ After a Virginia jury convicted him of robbery and capital murder, Terry Williams was sentenced to die. ${ }^{96}$ Williams contended on habeas that he had been deprived of his Sixth Amendment right to effective assistance of counsel, ${ }^{97}$ under the standard established in Strickland $v$. Washington, ${ }^{98}$ during his sentencing proceedings. ${ }^{99}$ Five Justices, led by Justice O'Connor, rejected the view that Congress's sole intention was to codify Teague when it enacted $\S 2254(\mathrm{~d})^{100}$ and concluded that

${ }^{95} 529$ U.S. 362 (2000). Writing on behalf of five other former Article III judges, Judge Abner Mikva filed an amicus brief urging the Court to reject any interpretation of $\$ 2254$ (d) that would require a federal habeas court to defer to a state court's resolution of a pure question of law or a mixed question of law and fact. Any interpretation requiring such deference, Judge Mikva argued, would unconstitutionally deprive the federal courts of the judicial power. See Motion of Marvin E. Frankel et al. for Leave to Appear as Amici Curiae and Brief in Support of Petitioner at 13, Williams v. Taylor, 529 U.S. 362 (2000) (No. 98-8384). The American Bar Association advanced comparable arguments. See Brief of Amicus Curiae American Bar Association in Support of Petitioner at 26-30, Williams v. Taylor, 529 U.S. 362 (2000) (No. 98-8384).

${ }_{96}$ Williams, 529 U.S. at $367-70$.

${ }^{97}$ See U.S. CONST. amend. VI ("In all criminal prosecutions, the accused shall enjoy the right ... to have the Assistance of Counsel for his defence.").

${ }_{98} 466$ U.S. 668, 687 (1984) (holding that to prove a violation of her Sixth Amendment right to counsel, a defendant must show "that counsel's performance was deficient" and "that the deficient performance prejudiced the defense").

${ }_{99}$ Williams, 529 U.S. at 370-74.

${ }^{100}$ As the Williams Court acknowledged, the statute plainly does occupy much of the same territory as Teague. With respect to $\S 2254$ (d)'s reference to "clearly established Federal law, as determined by the Supreme Court of the United States," for example, the Williams Court stated that "whatever would qualify as an old rule under our Teague jurisprudence will constitute "clearly established Federal law" for purposes of the statute, with the caveat that, unlike Teague, the statute "restricts the source of clearly established law to this Court's jurisprudence." Id. at 412. Moreover, Teague and $\S 2254(\mathrm{~d})$ share a deterrence rationale. In Teague, the plurality quoted Justice Harlan for the proposition that a chief purpose of federal habeas review is to provide the state courts with "'a necessary additional incentive" to abide by " established constitutional standards," and that this "'deterrence function"" is not served by recognizing new rules of law on habeas review. See Teague, 489 U.S. at 306 (plurality opinion) (quoting Desist v. United States, 394 U.S. 244, 262-63 (1969) (Harlan, J., dissenting)). By designating "clearly established federal law" as the benchmark for its application, § 2254(d) similarly seems intended to serve a deterrence function. See Chen, supra note 90, at 603-21 (arguing that deterrence is the only "principled defense" one can raise for $\$ 2254$ (d), but that the deterrence rationale is unpersuasive).

Yet the statute and Teague are not coextensive. The statute makes no reference to Teague's two narrow exceptions, for example, thereby leaving their fate uncertain. $C f$. Harvard Note, supra note 90, at 1884-85 (arguing that Teague's two exceptions are rooted in due process concerns, and so survived AEDPA's enactment); supra note 68 (describing the two exceptions). Moreover, $\S 2254$ (d) does not speak to instances in which the state courts did not adjudicate the habeas applicant's claim on the merits, yet the claim has not been deemed 
$\S 2254$ (d) also "places a new constraint" on federal habeas courts' ability to review state courts' applications of law to fact. ${ }^{101}$ Six Justices, led by Justice Stevens, concluded that Williams had satisfied $\S 2254$ (d)'s standard. ${ }^{102}$

In the portion of its opinion written by Justice O'Connor, the Court concluded that the "contrary to" and "unreasonable application of" clauses in $\S 2254$ (d) have distinct meanings. ${ }^{103}$ The Court identified two different ways in which a state court's ruling will be deemed "contrary to" clearly established Supreme Court precedent: (1) "if the state court applies a rule that contradicts the governing law set forth in our cases" and (2) "if the state court confronts a set of facts that are materially indistinguishable from a decision of this Court and nevertheless arrives at a result different from our precedent." 104 The Court then declared that a state court's application of Supreme Court precedent will be deemed "unreasonable" if the state court's decision "correctly identifies the governing legal rule but applies it unreasonably to the facts of [the] particular prisoner's case." 105

procedurally barred; Teague presumably continues to control in these cases. Accord Fisher v. Texas, 169 F.3d 295, 304 (5th Cir. 1999); Green v. French, 143 F.3d 865, 874 (4th Cir. 1998), cert. denied, 525 U.S. 1090 (1999).

${ }^{101}$ Williams, 529 U.S. at 411-13. The Court thereby rejected the conclusion of Justices Stevens, Souter, Ginsburg, and Breyer that $\S 2254(d)$ simply expressed "a 'mood' that the federal judiciary must respect," under which federal courts would "attend with the utmost care to state-court decisions," but would nevertheless continue to review questions of law and mixed questions of law and fact de novo. See id. at 386 (Stevens, J., concurring in the judgment); see also Yackle, Primer, supra note 90, at 413 (arguing that Congress intended $\S 2254$ (d) to have a "psychological effect" on federal judges by requiring that they begin their analysis by focusing closely on the state courts' analysis and conclusions). The Court also held that the statute "refers to the holdings, as opposed to the dicta, of this Court's decisions as of the time of the relevant state-court decision." Williams, 529 U.S. at 412.

${ }^{102}$ See Williams, 529 U.S. at 390-98. Joining this portion of Justice Stevens's opinion were Justices O'Connor, Kennedy, Souter, Ginsburg, and Breyer.

${ }^{103}$ See id. at 404; see also The Supreme Court, 1999 Term-Leading Cases, 114 HARV. L. REV. 179, 321-22, 326 (2000) (discussing Williams).

104 Williams, 529 U.S. at 405-06. As an example of the first scenario, the Court explained that a state court would apply a nule that contradicts Supreme Court precedent if it required a prisoner to prove his ineffective-assistance-of-counsel claim by a preponderance of the evidence, rather than by the "reasonable probability" standard established in Strickland. Id. at 405-06.

${ }^{105}$ Id. at $407-08$. The Court indicated that state courts' applications of law to fact might also be "unreasonable" for purposes of $\$ 2254$ (d) if they "unreasonably extend a legal principle from our precedent to a new context where it should not apply (or unreasonably refuse to extend a legal principle to a new context where it should apply)." Id. at 408 (noting that the Fourth Circuit had so held in Green v. French, 143 F.3d 865, 869-70 (4th Cir. 1998), cert. denied, 525 U.S. 1090 (1999)). The Court concluded, however, that '[t]oday's case does not require us to decide how such 'extension of legal principle' cases should be treated under $\S 2254(\mathrm{~d})(1)$." Williams, 529 U.S. at 408-09. The Court addressed the "extension" issue just 
When is an application of a correctly identified rule "unreasonable"? The Court rejected the Fourth Circuit's stringent standard, which held that a ruling on a mixed question is unreasonable "only if the state court has applied federal law "in a manner that reasonable jurists would all agree is unreasonable." 106 While noting that the Court employs comparable terminology when determining whether an outcome was dictated by precedent for purposes of Teague, ${ }^{107}$ the Court stated that employing such a standard here would be misleading (just as the comparable standard is often misleading in the Teague context) because it wrongly suggests that the standard is a subjective one. ${ }^{108}$ Just as the "reasonable jurist" standard under Teague is objective, so too does $\S 2254(\mathrm{~d})$ call for a determination of the objective reasonableness of a state court's application of federal law to fact. ${ }^{109}$ Thus, habeas relief is not barred merely because the state court's reasoning has been endorsed by at least one reasonable-seeming state or federal judge. ${ }^{110}$

The Court then emphasized what it perceived to be a fundamental distinction-a distinction entertained by Justice Thomas in $W_{e s t} t^{111}$ and now endorsed by Congress:

The term "unreasonable" is no doubt difficult to define. That said, it is a common term in the legal world and, accordingly, federal judges are familiar with its meaning. For purposes of today's opinion, the most important point is that an unreasonable application of federal law is different from an incorrect application of federal law. . . . Congress specifically used the word "unreasonable," and not a term like "erroneous" or "incorrect." Under $§ 2254(\mathrm{~d})(1)$ 's "unreasonable application" clause, then, a federal habeas court may not issue the writ simply because that court concludes in its independent judgment that the relevant statecourt decision applied clearly established federal law erroneously or incorrectly. Rather, that application must also be unreasonable. ${ }^{112}$

three weeks later in Ramdass v. Angelone, 530 U.S. 156 (2000). See infra notes 119-35 and accompanying text.

${ }^{106}$ Williams, 529 U.S. at 409 (quoting Green, 143 F.3d at 870).

${ }^{107}$ Id. (citing Lambrix v. Singletary, 520 U.S. 518, 528 (1997) and Graham v. Collins, 506 U.S. 461, 477 (1993)); see supra notes 68-72 and accompanying text (discussing Teague's rule of non-retroactivity).

${ }^{108}$ Williams, 529 U.S. at $409-11$.

${ }^{109}$ Id. The Court's reference to objective reasonableness does echo the language used in some of the Court's Teague cases. See, e.g., O'Dell v. Netherland, 521 U.S. 151, 156 (1997) ("[W]e will not disturb a final state conviction or sentence unless it can be said that a state court, at the time the conviction or sentence became final, would have acted objectively unreasonably by not extending the relief later sought in federal court.").

${ }^{110}$ Williams, 529 U.S. at $409-11$.

${ }^{111}$ See supra notes 77-81 and accompanying text.

112 Williams, 529 U.S. at $410-11$ (emphasis added). The Court did not address the 
Led by Justice Stevens, six Justices concluded that the Virginia Supreme Court's denial of Williams's ineffective-assistance-of-counsel claim was both "contrary to" and an "unreasonable application of" Supreme Court precedent. ${ }^{113}$ The Virginia Supreme Court's ruling was contrary to federal law because it grafted a "fundamental faimess" inquiry onto the well-established Strickland standard used to evaluate claims of ineffective assistance. ${ }^{114}$ That court's ruling also rested upon an unreasonable application of Strickland's two-pronged standard. ${ }^{115}$ Williams's attomeys had clearly fallen "short of professional standards" in their handling of Williams's sentencing proceedings by failing to examine numerous records concerning Williams's "nightmarish childhood," failing to introduce evidence that Williams was "borderline mentally retarded," and failing to obtain evidence of Williams's favorable conduct while in prison. ${ }^{116}$ Moreover, by "fail[ing] to accord appropriate weight to the body of mitigation evidence available to trial counsel," the Virginia Supreme Court had unreasonably concluded that these failures had not prejudiced Williams. ${ }^{117}$

The Court did not elucidate the methodology it used to determine whether the Virginia court's erroneous ruling was reasonable or unreasonable. Indeed, in three dissenters' view, the Virginia court had reasonably concluded that a jury would have sentenced Williams to death even if it had heard all of the available mitigating evidence, because "there was strong evidence that [Williams] would continue to be a danger to society, both in and out of prison." principled grounds did those in the majority and those in the dissent part company? The respective opinions do not say-each group of Justices simply recites the evidence it finds persuasive and declares whether it thinks the Virginia court gave that evidence its due.

Three weeks later, a plurality of the Court recognized a second way in which a state court's application of law to fact may be unreasonable. In Ramdass $v$.

constitutional propriety of its nuling. Yet unless one believes that the Court adopted an interpretation of the statute that it believes is unconstitutional, it is clear that the Court rejected Justice Stevens's view that an "unreasonably erroneous" standard deprives the federal courts of their Article III authority to "interpret federal law." See id. at 378-79 (opinion of Stevens, J.).

${ }^{113}$ See id. at 390-91. Chief Justice Rehnquist and Justices Scalia and Thomas dissented in part, concluding that the Virginia Supreme Court's decision was neither "contrary to" nor an "unreasonable application of" Supreme Court precedent. See id. at 416-19 (Rehnquist, C.J., concurring in part and dissenting in part).

${ }^{114}$ Id. at 391-95 (holding that the Virginia court had misinterpreted the Court's rulings in Lockhart v. Fretwell, 506 U.S. 364 (1993), and Nix v. Whiteside, 475 U.S. 157 (1986)).

${ }^{115}$ Id. at 397.

${ }^{116}$ Id. at 395-96.

117 Id. at 398.

${ }^{118}$ Id. at 418-19 (Rehnquist, C.J., concurring in part and dissenting in part); see supra note 113. 
Angelone, ${ }^{119}$ a Virginia jury had found Bobby Lee Ramdass guilty of murder. ${ }^{120}$ During its sentencing deliberations, the jury asked the judge whether, if given a life sentence, Ramdass would ever become eligible for parole. After the judge instructed the jury that it was not to consider such matters, the jury recommended-and the trial court imposed-a sentence of death. ${ }^{121}$ On direct review, Ramdass argued that he had been ineligible for parole under Virginia's "three strikes" law and that the trial court should have instructed the jury accordingly. ${ }^{122}$ The state courts denied the claim. While Ramdass's petition to the Supreme Court for a writ of certiorari was pending, however, the Court decided Simmons $v$. South Carolina, ${ }^{123}$ holding that, if a prosecutor emphasizes a capital defendant's future dangerousness and the defendant is ineligible for parole at the time the sentencing jury is deliberating, the jury must be so informed. ${ }^{124}$ The Court granted Ramdass's petition and remanded for reconsideration in light of Simmons. The Virginia Supreme Court reaffirmed Ramdass's death sentence, finding that Ramdass had not been ineligible for parole at the time of his capital sentencing. While a separate jury had found him guilty of a separate (and third) offense, the trial court had not yet formally entered a final judgment on that verdict at the time that Ramdass's capital jury was deliberating. ${ }^{125}$

On federal habeas review, Ramdass argued that the Virginia Supreme Court had erred by refusing to grant him relief pursuant to Simmons. ${ }^{126}$ A plurality of the Supreme Court rejected Ramdass's claim. Writing for the plurality-yet perhaps stating the views of five members of the Court ${ }^{127}$-Justice Kennedy first 1993)).

119530 U.S. $156(2000)$.

${ }^{120} \mathrm{Id}$. at $159-60$ (plurality opinion).

${ }^{121}$ Id. at 162 (plurality opinion).

${ }^{122}$ Id. at $162-63$ (plurality opinion) (citing VA. CODE ANN. $\$ 53.1-151(\mathrm{Bl})$ (Michie ${ }_{123} 512$ U.S. 154 (1994).

${ }^{124}$ Id. at 163-64; Ramdass, 530 U.S. at 163-64 (plurality opinion); see also Shafer v. South Carolina, 121 S. Ct. 1263, 1271-73 (2001) (reaffirming Simmons).

${ }_{125}$ Ramdass, 530 U.S. at 164 (plurality opinion).

${ }^{126} \mathrm{Id}$.

${ }^{127}$ Chief Justice Rehnquist and Justices Scalia and Thomas joined Justice Kennedy's plurality opinion. See id. at 159 (plurality opinion). Justice O'Connor filed an opinion concurring in the judgment, but agreed that, "[f]or the reasons explained in the plurality opinion, the Virginia Supreme Court's decision was neither contrary to, nor an unreasonable application of, our holding in Simmons." Id. at 180 (O'Connor, J., concurring in the judgment). Yet, unlike the plurality, Justice $O$ 'Connor did not directly comment upon the legal significance of a state court's unreasonable refusal to extend Supreme Court precedent to a new factual setting. Instead, she focused her brief comments entirely on her conclusion that the state court's ruling had not been "contrary to" Simmons. See id. at 180-81 (O'Connor, J., concurring in the judgment). The lower federal courts have divided on the question of whether the plurality's reasoning commanded a majority of the Court. Compare Lurie v. Wittner, 228 F.3d 113, 130 (2d Cir. 2000) (concluding that "Justice O'Connor's opinion is arguably more narrow than the 
found that the Virginia Supreme Court's ruling was not "contrary to" Simmons because, unlike the prisoner in that case, Ramdass was not yet ineligible for parole at the time the jury recommended his sentence. Final judgment on his third felony had not yet been formally entered. ${ }^{128}$ Turning to the statute's "unreasonable application" clause, Justice Kennedy stated that a federal court may grant habeas relief if, "under clearly established federal law, the state court was unreasonable in refusing to extend the governing legal principle to a context in which the principle should have controlled." 29 The plurality held that the Virginia justices had not acted unreasonably when they refused to extend Simmons to the facts of Ramdass's case. ${ }^{130}$ To apply Simmons in cases such as this, Justice Kennedy wrote, "would require courts to evaluate the probability of future events [such as the issuance of post-verdict relief on the third felony conviction] in cases where a three-strikes law is the issue"131 and would provoke litigation on "peripheral" matters. ${ }^{132}$ Thus, the plurality concluded, " $[t]$ he Virginia

plurality's and therefore constitutes the holding of the Court"), and Santorelli v. Cowhey, 124 F. Supp. 2d 853, 857 (S.D.N.Y. 2000) (noting that the Second Circuit has not yet determined "whether $\S 2254(\mathrm{~d})(1)$ is triggered where there is an unreasonable refusal by a state court to extend Supreme Court precedents"), with McCoy v. Hubbard, No. 99-16759, 2000 U.S. App. LEXIS 18157, at *3 (9th Cir. July 25, 2000) (citing the Ramdass plurality's opinion as binding authority), and O'Shields v. McDonnell, No. 98-0171-CB-L, 2000 U.S. Dist. LEXIS 19831, at *9 (S.D. Ala. Nov. 29, 2000) (same), and Hall v. Palmateer, No. 99-1318-JO, 2000 U.S. Dist. LEXIS 16936, at *6 (D. Or. Nov. 6, 2000) (same), and Thurman v. Page, No. 98-C-0092, 2000 U.S. Dist. LEXIS 12404, at *12 (N.D. III. Aug. 18, 2000) (same).

${ }^{128}$ Ramdass, 530 U.S. at 166-67 (plurality opinion); see supra notes $103-04$ and accompanying text (discussing $§ 2254$ (d)'s "contrary to" clause).

${ }^{129}$ Ramdass, 530 U.S. at 166 (plurality opinion); cf. Butler v. McKellar, 494 U.S. 407, 412-13 (1990) (acknowledging that Teague's new-rule determination is difficult when the decision relied upon was "reached by an extension of the reasoning of prior cases"). Ramdass illustrates the danger in assuming that $\S 2254$ (d)'s "unreasonable application" clause strictly correlates with review of mixed questions of law and fact. Ordinarily, a mixed question is understood to be a question that asks whether a given set of facts falls within the compass of an identified legal standard. See supra note 34 and accompanying text. In Ramdass, however, the plurality applied the "unreasonable application" clause when determining whether a legal standard was well-suited to a particular set of facts. In some respects, that inquiry concems a pure question of law.

${ }_{130}$ Ramdass, 530 U.S. at $169-70$ (plurality opinion).

${ }^{131}$ Id. at 169 (plurality opinion). With respect to Ramdass's third felony, for which final judgment had not yet been entered, the trial court would have had to predict whether Ramdass would be granted some form of post-verdict relief. If Ramdass's third felony conviction were vacated, the three-strikes law would not apply and Ramdass would be eligible for parole on his murder conviction. See id.

${ }^{132}$ Id. at 170 (plurality opinion). Even if instructed that Ramdass would not be eligible for parole, the plurality stated, the jury would have been entitled to sentence Ramdass to death because he could escape prison or be granted a pardon and then commit additional violent acts. Id. The four dissenting Justices argued that Simmons had already addressed the plurality's 
Supreme Court had good reason not to extend Simmons beyond the circumstances of that case."133

As in Williams, the Ramdass Court failed to explain the means by which it determined whether the Virginia court's ruling was reasonable. Five Justices determined that the Virginia Supreme Court had reasonably concluded that Simmons should not apply when judgment on a defendant's third offense has not yet been entered; four Justices disagreed and argued that Simmons already applied to such cases. ${ }^{134}$ None of the Justices' opinions makes clear how one draws the line that separates reasonable and unreasonable conclusions on the matter. ${ }^{135}$

In the wake of Williams and Ramdass, the lower federal courts have begun to divide on important matters. Some courts have held, for example, that a federal habeas court must determine whether the outcome selected by the state court is unreasonable, while other courts have held that a federal habeas court must determine whether the state court's analysis of the applicant's federal claim is unreasonable. ${ }^{136}$ Similarly, some courts have indicated that a state court's ruling is not an "adjudication on the merits" entitled to deferential review under $\$ 2254$ (d) unless the ruling contains a discussion of the court's reasoning, ${ }^{137}$ while other courts have held that a summary adjudication by a state court can indeed be an adjudication entitled to deference. ${ }^{138}$ Purporting to resolve such matters, however, largely presupposes that one can answer a more fundamental question: Regardless of whether one focuses on outcomes or analyses, by what means may a federal habeas court distinguish between reasonably and unreasonably erroneous applications of clearly established federal law?

concerns and that no "extension" of Simmons was necessary in order to grant Ramdass's application for habeas relief. In the eyes of these Justices, the Virginia Supreme Court's ruling was "contrary to" Simmons within the meaning of $\$ 2254(d)$. See id. at 199-207 \& n.31 (Stevens, J., dissenting).

${ }^{133}$ Id. at 170 (plurality opinion); see also Kelly v. South Carolina, 122 S. Ct. 726, 730-34 (2002) (further clarifying the reach of Simmons).

${ }_{134}$ See Ramdass, 530 U.S. at 169-70 (plurality opinion); id. at 199-207 (Stevens, J., dissenting); supra note 127 (discussing Justice O'Connor's ambiguous opinion).

${ }^{135}$ Cf. Penry v. Johnson, 121 S. Ct. 1910, 1918 (2001) (citing Williams but providing no further clarification).

${ }^{136}$ Compare Neal v. Puckett, 239 F.3d 683, 695-96 (5th Cir. 2001) (adopting the former position), with Washington v. Hofbauer, 228 F.3d 689, 703-07 (6th Cir. 2000) (focusing on the state court's analysis).

${ }^{137}$ See, e.g., Hameen v. Delaware, 212 F.3d 226, 248 (3d Cir. 2000) (finding that a state court's ruling is not entitled to deference as an adjudication on the merits if it is not clear that the state court "took into account controlling Supreme Court decisions"), cert. denied, 121 S. Ct. 1365 (2001).

${ }^{138}$ See, e.g., Valdez v. Cockrell, 274 F.3d 941, 951 (5th Cir. 2001) ("[W]e hold that a full and fair hearing is not a precondition to ... applying $§ 2254$ (d)'s standards of review."); Sellan v. Kuhlman, 261 F.3d 303, 309-14 (2d Cir. 2001); Bell v. Jarvis, 236 F.3d 149, 158, 163 (4th Cir. 2000); Aycox v. Lytle, 196 F.3d 1174, 1177-78 (10th Cir. 1999). 


\section{THE SEARCH FOR USEFUL COMPARISONS}

Despite the predominance of mixed questions in claims raised on federal habeas review and the dramatic frequency with which issues concerning the new "unreasonably erroneous" standard now arise, ${ }^{139}$ the Court has not provided specific guidance on how one should distinguish between reasonable and unreasonable errors. ${ }^{140}$ In Williams and Ramdass, the Justices themselves failed to agree on whether the Virginia Supreme Court's reasoning had been reasonable, and none of the Justices' opinions clearly describes the means by which reasonable and unreasonable rulings may be distinguished. In this section, I briefly examine four well-known standards of review that, at first glance, might appear comparable to the "unreasonably erroneous" standard, and so might offer insights about how that standard should be applied: the "clearly erroneous" standard of review, the "abuse of discretion" standard of review, the standard used to determine whether a district court properly imposed Rule 11 sanctions, and the standard used when reviewing administrative agencies' interpretations of ambiguous statutes. Although there are points of comparison in each instance, none sufficiently illuminates the manner in which federal courts are to identify unreasonable legal reasoning. The "unreasonably erroneous" standard's features are nevertheless highlighted by the comparisons.

\section{A. "Clearly Erroneous" Review of Factual Findings}

Rule 52(a) of the Federal Rules of Civil Procedure states that an appellate court must accept a district court's factual findings unless those findings are "clearly erroneous." ${ }^{, 141}$ In United States v. United States Gypsum Co ${ }^{142}$ the Court provided an enduring interpretation of Rule 52(a)'s standard: "A finding is 'clearly erroneous' when although there is evidence to support it, the reviewing court on the entire evidence is left with the definite and firm conviction that a mistake has been committed." 143 To reverse a district court's factual findings,

${ }^{139}$ See supra notes 41-52 and accompanying text (listing some of the many mixed questions that repeatedly arise in federal habeas proceedings). In February 2002, a Lexis search indicated that the federal courts already had cited Williams or Ramdass more than 1,200 times.

${ }^{140}$ See supra notes 8-9 and accompanying text.

${ }^{141}$ FED. R. CIV. P. 52(a) ("Findings of fact, whether based on oral or documentary evidence, shall not be set aside unless clearly erroneous, and due regard shall be given to the opportunity of the trial court to judge of the credibility of the witnesses.").

142333 U.S. 364 (1948).

${ }^{143}$ Id. at 395 (emphasis added); cf. United States v. Aluminum Co. of Am., 148 F.2d 416, 433 (2d Cir. 1945) (Hand, J.). The Second Circuit stated:

It is idle to try to define the meaning of the phrase 'clearly erroneous'; all that can be profitably said is that an appellate court, though it will hesitate less to reverse the finding of 
therefore, an appellate court must do more than merely find that "it would have decided the case differently" or that "it would have weighed the evidence differently."144 Instead, the appellate court must find that the trial court's "account of the evidence is [not] plausible in light of the record viewed in its entirety."145

Writing for four Justices in Williams, Justice Stevens echoed (but did not expressly cite) the Gypsum standard, asserting that a state court's application of federal law is unreasonable when a "thorough analysis by a federal court produces a firm conviction that that judgment is infected by constitutional error., ${ }^{146}$ Despite Justice Stevens's failure to win the vote of a majority for that portion of his opinion, ${ }^{147}$ the United States Court of Appeals for the Ninth Circuit has concluded that the "clearly erroneous" standard is "the source of the most useful body of precedent" for making sense of Williams and $\S 2254(\mathrm{~d}),{ }^{148}$ and it appears that at least two other courts have concurred. ${ }^{149} \mathrm{~A}$ handful of courts addressing the

a judge than that of an administrative tribunal or of a jury, will nevertheless reverse it most reluctantly and only when well persuaded.

Aluminum Co. of Am., 148 F.2d at 433.

${ }^{144}$ Anderson v. City of Bessemer City, 470 U.S. 564, 573-74 (1985).

${ }^{145}$ Id.; see also id. at 574 (stating that, when "there are two permissible views of the evidence, the factfinder's choice between them cannot be clearly erroneous"). By mandating such strong deference to the trial courts, the "clearly erroneous" standard takes account of trial courts' expertise in resolving factual disputes, trial courts' opportunity to make live credibility determinations, and the need to spare parties the time and expense of repeatedly trying to convince different judges of the underlying facts in a case. Id. at 574-75.

${ }^{146}$ Williams v. Taylor, 529 U.S. 362, 389 (2000) (opinion of Stevens, J.) (emphasis added).

${ }^{147}$ Justice Stevens acknowledged that the Court had rejected his "firm conviction" formulation of the standard prescribed by $\S 2254$ (d). See id.

${ }^{148}$ In Van Tran v. Lindsey, 212 F.3d 1143 (9th Cir.), cert. denied, 531 U.S. 944 (2000), the Ninth Circuit declared:

[W] hold that under AEDPA we must reverse a state court's decision as involving an "unreasonable application" of clearly established federal law when our independent review of the legal question does not merely allow us ultimately to conclude that the petitioner has the better of two reasonable legal arguments, but rather leaves us with a firm conviction that one answer, the one rejected by the court, was correct and the other, the application of the federal law that the court adopted, was erroneous - in other words that clear error occurred.

Id. at 1153-54 (emphasis added) (internal quotation omitted).

${ }^{149}$ See Gonzales v. McKune, 247 F.3d 1066, 1076-77 (10th Cir. 2001) (applying the "clearly erroneous" standard under the purported authority of $\S 2254$ (d) and Williams); Ventura v. Artuz, No. 99-CIV-12025, 2000 U.S. Dist. LEXIS 10167, at *18 n.8 (S.D.N.Y. July 19, 2000) (sympathetically citing the Ninth Circuit's adoption of the "clearly erroneous" standard). Compare Williams v. Matesanz, 230 F.3d 421, 429 (1st Cir. 2000) ("When there are two plausible outcomes that can result from a reasoned application of clearly established Supreme Court precedent to a particular set of facts, the state court's choice between those outcomes, 
matter prior to Williams reached the same conclusion. ${ }^{150}$ That analogy, although apt in certain respects, ultimately fails.

Without question, there are parallels between the "unreasonably erroneous" and "clearly erroneous" standards. Both standards instruct the reviewing court that it may not disregard the ruling below merely because it would have decided the issue differently. ${ }^{151}$ Both standards appear to focus, at least in part, on whether the conclusion under review is plausible. ${ }^{152}$ Moreover, the federal courts sometimes apply the "clearly erroneous" standard to mixed questions, particularly when the factual elements of those questions predominate. ${ }^{153}$ The United States

whether right or wrong, cannot constitute a basis for habeas relief under the second branch of section 2254(d)(1)."), with supra note 145 (setting forth the Court's comparable declaration in Anderson conceming review of a district court's factual findings for clear error).

${ }^{150}$ See, e.g., Holman v. Gilmore, 126 F.3d 876, 882 (7th Cir. 1997) (holding that "only a clear error in applying Strickland's standard [for ineffective-assistance-of-counsel claims] would support a writ of habeas corpus"), cert. denied sub nom. Holman v. Page, 522 U.S. 1150 (1998); Mata v. Johnson, 99 F.3d 1261, 1267 (5th Cir. 1996) (concluding that the standard required by $\S 2254$ (d)'s "unreasonable application" clause "is probably most closely akin to the traditional 'clearly erroneous' standard than to any other established standard of review"), vacated in part on other grounds, 105 F.3d 209 (5th Cir. 1997); cf. Hennon v. Cooper, 109 F.3d 330, 334-35 (7th Cir.) (stating that \$2254(d)'s "unreasonable application" clause appears "stronger than 'erroneous' and maybe stronger than 'clearly erroneous,", and concluding that the state court's ruling must be "at least minimally consistent with the facts and circumstances of the case"), cert. denied, 522 U.S. 819 (1997).

${ }^{151}$ Compare Williams v. Taylor, S29 U.S. 362, 411 (2000) ("Under § 2254(d)(1)'s 'unreasonable application' clause, ... a federal habeas court may not issue the writ simply because that court concludes in its independent judgment that the relevant state-court decision applied clearly established federal law erroneously or incorrectly."), with Anderson v. City of Bessemer City, 470 U.S. 564, 573-74 (1985) (stating that an appellate court may not reverse a district court's factual findings merely because "it would have weighed the evidence differently").

${ }^{152}$ Compare Williams, 529 U.S. at 411 (stating that a federal court may not reverse a state court's ruling unless that ruling is "unreasonable"), and Hall v. Washington, 106 F.3d 742, 748-49 (7th Cir. 1997) (stating that a state court's application of law to fact must "stand if it is one of several equally plausible outcomes"), with Anderson, 470 U.S. at 573-74 (stating that a district court's factual finding is not "clearly erroneous" if it reflects a "plausible" view of the evidence).

${ }^{153}$ See, e.g., United States v. Reilly, 224 F.3d 986, 994 (9th Cir. 2000) ("We review the district court's application of the inevitable discovery doctrine for clear error because, although it is a mixed question of law and fact, it is essentially a factual inquiry."); Tahoe-Sierra Preservation Council, Inc. v. Tahoe Regional Planning Agency, 216 F.3d 764, 783 (9th Cir. 2000) ("[W]e review findings of proximate cause [in a Section 1983 action] for clear error, even though they present mixed questions of law and fact.'); Van Tran, 212 F.3d at 1152-53 n.14 (listing instances in which the Ninth Circuit has reviewed lower courts' "legal determinations" only for clear error); Naimie v. Cytozyme Labs., Inc., 174 F.3d 1104, 1111 (10th Cir. 1999) ("We review mixed questions under either the clearly erroneous standard or de novo standard depending on whether the mixed question involves primarily a factual inquiry or 
Court of Appeals for the Seventh Circuit has even declared that it now reviews nearly all district court rulings on mixed questions only for clear error. ${ }^{154}$

Yet $\$ 2254$ (d) does not instruct federal habeas courts simply to review state courts' rulings for clear error. First, and most fundamentally, the "clearly erroneous" and "unreasonably erroneous" standards focus on two different phenomena. As Gypsum explains, applying the "clearly erroneous" standard requires that the reviewing court assess its degree of conviction that an error has occurred. ${ }^{155}$ The "clear error" test "focuses on judicial confidence rather than margin of error."156 By emphasizing the distinction between reasonable errors and unreasonable errors-and concluding that Congress has authorized habeas relief only in cases of the latter-Williams leaves no room to conclude that a federal court may grant habeas relief if the state court committed an objectively reasonable error, so long as the federal court is firmly convinced that the state court did indeed err. ${ }^{157}$ Whatever $\S 2254$ (d) requires, it is not simply a firm

the consideration of legal principles.") (citation and internal quotation omitted); United States v. Bergodere, 40 F.3d 512, 516 (1st Cir. 1994) (holding that, when a defendant claims that the prosecutor unlawfully used her peremptory challenges to remove persons of a particular race from the jury, the defendant has presented "a mixed question of law and fact" that is "factsensitive, and, therefore, should be reviewed under the familiar clear-error standard"), cert. denied, 514 U.S. 1055 (1995); see also supra notes 35-40 and accompanying text (discussing the functional method of identifying mixed questions). See generally 9A CHARLES A. WRIGHT \& ARTHUR R. MILleR, Federal PRACTICE AND PROCEDURE $§ 2589$ (1995) (stating that the courts have identified "a tremendous variety of matters" that present mixed questions and are subject to clear-error review).

${ }^{154}$ United States v. Frederick, 182 F.3d 496, 499 (7th Cir. 1999) ("The presumption in this circuit is and we hope will remain that the clear-error standard is the proper standard for appellate review of determinations of mixed questions of fact and law," with exceptions being made when "the risk of error is thought sufficiently serious to warrant a more searching than normal review for error."), cert. denied, 528 U.S. 1154 (2000); see Evan T. Lee, Principled Decision Making and the Proper Role of Federal Appellate Courts: The Mixed Questions Conflict, 64 S. CAL. L. REV. 235, 236-37 (1991) (stating that the Seventh Circuit's approach recognizes that an appellate court's principal function is "to exercise control over the development of law").

${ }_{155}$ See United States v. United States Gypsum Co., 333 U.S. 364, 395 (1948).

${ }^{156}$ CHILDRESS \& DAVIS, supra note $30, \S 2.05$.

${ }^{157}$ See Williams, 529 U.S. at 411 . The Second Circuit has concluded (correctly) that the Ninth Circuit's "clear error" approach wrongly

focuses on how sure the habeas court is that the state court has committed error, not whether the state court decision reveals an increment of wrongness beyond error. Of course, a habeas court will likely be firmly convinced of its conclusion whenever a state court has committed a mistake more egregious than error, but it might also be firmly convinced that just an ordinary error has occurred.

Francis S. v. Stone, 221 F.3d 100, 110 (2d Cir. 2000); cf. Bell v. Jarvis, 236 F.3d 149, 162 n.9 (4th Cir. 2000) (declining 'to adopt the 'clearly erroneous' standard as the standard for 
conviction that the state court has made a mistake.

Second, in a non-habeas setting, the Court recently cautioned the Seventh Circuit that it should be reticent to use the term "clearly erroneous" when describing a deferential standard of review for mixed questions. In Ornelas $v$. United States, ${ }^{158}$ the Court noted that the Seventh Circuit had reviewed a district court's rulings on two mixed questions for clear error. ${ }^{159}$ The Court held that a federal appellate court must review those two questions de novo. ${ }^{160}$ The Court emphasized, however, that even if a deferential standard were appropriate, the Seventh Circuit should have applied a standard akin to "abuse of discretion.""61 "“Clear error," the Court explained, "is a term of art derived from Rule 52(a) of the Federal Rules of Civil Procedure, and applies when reviewing questions of fact." ${ }^{162}$ Ornelas does not suggest that review for clear error is never appropriate for mixed questions, nor does it speak directly to the appropriate standard on habeas review. But it does reiterate that clear-error review is generally applied only when the question before the reviewing court is primarily factual in nature. ${ }^{163}$ Broadly adopting a "clearly erroneous" standard of review for all state court rulings on mixed questions would be contrary to that principle.

Third, both Congress and the Court are exceedingly familiar with the "clearly erroneous" standard and presumably would have used that phrase if it denoted what they intended to say. Congress has expressly adopted that standard in a variety of other contexts ${ }^{164}$ and the Court's use of the phrase can be traced back to

reasonableness under $\$ 2254(\mathrm{~d}) ")$.
${ }_{158} 517$ U.S. $690(1996)$.
${ }^{159}$ Id. at $693-95$. The first question was whether an officer had reasonable cause to justify a Terry stop. See Terry v. Ohio, 392 U.S. 1, 30 (1968) (holding that a police officer may briefly detain a person if the officer "observes unusual conduct which leads him reasonably to conclude ... that criminal activity may be afoot"). The second question was whether an officer had probable cause to conduct a warrantless search of a car. See Califomia v. Acevedo, 500 U.S. 565, 580 (1991) (holding that " $[t]$ he police may search an automobile and the containers within it where they have probable cause to believe contraband or evidence is contained").

${ }^{160}$ Ornelas, 517 U.S. at 696-99. See generally Jeffrey M. Grybowski, Note, The Appellate Role in Ensuring Justice in Fourth Amendment Controversies: Ornelas v. United States, 75 N.C. L. REV. 1819 (1997) (critiquing Ornelas); The Supreme Court, 1995 Term-Leading Cases, 10 HARV. L. REV. 135, 317-27 (1996) (same).

${ }^{161}$ Ornelas, 517 U.S. at 694 n.3. For a discussion of the "abuse of discretion" standard and its possible relation to the new "unreasonably erroneous" standard, see infra notes 166-85 and accompanying text.

${ }^{162}$ Ornelas, 517 U.S. at 694 n.3.

${ }^{163}$ Cf. supra note 39 (citing Patton v. Yount, 467 U.S. 1025, 1038 (1984), and Wainwright v. Witt, 469 U.S. 412,429 (1985), as instances in which the Court declared that federal habeas courts should apply a deferential standard of review to state courts' resolutions of particular mixed questions, because those questions raised primarily factual issues).

${ }^{164}$ See, e.g., 8 U.S.C. $\S \S 1535(\mathrm{a})(3)(\mathrm{B})$, (c)(4)(D) (1994); 20 U.S.C. $\S 7544(\mathrm{c})(1)$ (1994); 28 U.S.C. $\S 636(\mathrm{~b})(1)(\mathrm{A})(1994) ; 38$ U.S.C. $\$ 7261(\mathrm{a})(4)$ (1994); 42 U.S.C. $\S 1973 \mathrm{~g}(\mathrm{a})$ (1994); 
the days of equity. ${ }^{165}$ For all of these reasons, the "clearly erroneous" standard cannot be equated with the standard mandated by $\S 2254(\mathrm{~d})$.

\section{B. "Abuse of Discretion" Review of Rulings on Trial-Related Matters}

A great variety of rulings made by a trial court-particularly rulings relating to pleadings, discovery, and evidentiary objections - are reviewed by an appellate court for an "abuse of discretion."166 There are numerous definitions of the abuseof-discretion standard of review, "ranging from ones that would require the appellate court to come close to finding that the trial court had taken leave of its senses to others which differ from the definition of error by only the slightest nuance, with numerous variations between the extremes."167 Some courts have explained, for example, that a district court abuses its discretion if it "applies the incorrect legal standard, misapplies the correct legal standard, or relies upon clearly erroneous findings of fact." ${ }^{168}$ Others have said that a district court abuses its discretion if it makes a "clear error of judgment,"169 makes "an arbitrary, capricious, whimsical, or manifestly unreasonable judgment," "70 or makes a

50 U.S.C. $\S 1805(a)(5)$ (1994). A number of procedural rules employ the "clearly erroneous" standard as well. In addition to Rule 52(a), see FED. R. CIv. P. 53; FED. R. CIV. P. 72; FED. R. CRIM. P. 35(c); BANKR. R. 8013.

${ }^{165}$ See CHILDRESS \& DAVIS, supra note 30, $\$ 2.02$; Charles R. Calleros, Title VII and Rule 52(a): Standards of Appellate Review in Disparate Treatment Cases-Limiting the Reach of Pullman-Standard v. Swint, 58 TuL. L. REV. 403, 409-12 (1983).

${ }^{166}$ Kelly Kunsch, Standard of Review (State and Federal): A Primer, 18 SEATTLE U. L. REV. 11, 34 (1994); Maurice Rosenberg, Judicial Discretion of the Trial Court, Viewed From Above, 22 SYRACUSE L. REV. 635, 653, 657-58 (1971) [hereinafter Rosenberg, Judicial Discretion].

${ }^{167}$ Henry J. Friendly, Indiscretion About Discretion, 31 EMORY L.J. 747, 763 (1982); accord Rosenberg, Judicial Discretion, supra note 166, at 650 ("There are gradations of discretion, ranging from the toughest, most impenetrable variety to types that are too flimsy to ward off any appellate scrutiny that looks askance at the trial court's ruling."). See generally Maurice Rosenberg, Appellate Review of Trial Court Discretion, 79 F.R.D. 173, 173 (1979) [hereinafter Rosenberg, Appellate Review] ("Discretion is a pervasive yet elusive concept ....").

${ }^{168}$ Schenck v. City of Hudson, 114 F.3d 590, 593 (6th Cir. 1997); accord Latvian Shipping Co. v. Baltic Shipping Co., 99 F.3d 690, 692 (5th Cir. 1996) ("We will not find an abuse of discretion unless the district court's factual findings are clearly erroneous or incorrect legal standards were applied."). The Supreme Court has similarly held that "[a] district court by definition abuses its discretion when it makes an error of law." Koon v. United States, 518 U.S. 81,100 (1996).

${ }_{169}$ Purcell v. BankAtlantic Fin. Corp., 85 F.3d 1508, 1513 (11th Cir.), cert. denied sub nom. Am. Broad. Cos., Inc. v. BankAtlantic Fin. Corp., 519 U.S. 867 (1996).

${ }^{170}$ Woodworker's Supply, Inc. v. Principal Mut. Life Ins. Co., 170 F.3d 985, 992 (10th Cir. 1999); accord Moore v. Willis Indep. Sch. Dist., 233 F.3d 871, 876 (5th Cir. 2000) ("We ... will affirm [a district court's discovery rulings] unless they are arbitrary or clearly 
decision that the appellate court is "firmly convinced" is mistaken. ${ }^{171}$

In some of these incarnations, the abuse-of-discretion standard plainly rests, at least in part, upon notions of reasonableness. Moreover, the federal appellate courts apply the abuse-of-discretion standard when reviewing district courts' rulings on certain mixed questions of law and fact, such as whether evidence was admissible under the Federal Rules of Evidence. ${ }^{172}$ Yet any attempt to rely upon abuse-of-discretion cases for guidance in discerning the parameters of the "unreasonably erroneous" standard in a broad range of cases will encounter only limited success.

Notwithstanding its prevalence, the abuse-of-discretion standard is itself a standard whose contours have eluded courts and scholars. Judge Friendly conceded that "[m] ost definitions of discretion are not very helpful,"," while Maurice Rosenberg concluded that " $t]$ he term has no meaning or idea content that [he had] ever been able to discern." 174 To recast the "unreasonably erroneous" standard as one calling for review for abuse of discretion, therefore, is simply to exchange one opaque set of terms for another. What are "clear errors of judgment" or "manifestly unreasonable judgments"? Such judgments might very well encompass state courts' unreasonably erroneous applications of federal law, but to say that they do brings us no closer to understanding when $\S 2254$ (d) authorizes habeas relief.

Not only does the abuse-of-discretion standard suffer from a lack of analytic precision, but it also rests upon rationales that lack broadly applicable explanatory power in the context of federal habeas proceedings. As the United States Court of Appeals for the Third Circuit has explained, identifying the rationale for applying the abuse-of-discretion standard in a given case may help one to determine just when such an abuse has occurred:

The justifications for committing decisions to the discretion of the court are not uniform, and may vary with the specific type of decisions. Although the standard of review in such instances is generally framed as "abuse of discretion," in fact the scope of review will be directly related to the reason why that category or

unreasonable.'); Powers v. Eichen, 229 F.3d 1249, 1256 (9th Cir. 2000) ("The district court abuses its discretion when it [awards attorneys' fees using] a mechanical or formulaic approach that results in an unreasonable reward.").

${ }_{171}^{172}$ Romstadt v. Allstate Ins. Co., 59 F.3d 608, 615 (6th Cir. 1995).

${ }^{172}$ See, e.g., Gen. Elec. Co. v. Joiner, 522 U.S. 136, 141 (1997) ("'A]buse of discretion is the proper standard of review of a district court's evidentiary rulings."); $c f$. United States v. Comer, 93 F.3d 1271, 1277 (6th Cir.) (describing the Sixth Circuit's three-tiered standard of review-involving clear error, de novo, and abuse-of-discretion analysis-for matters arising under Rule 404(b) of the Federal Rules of Evidence), cert. denied, 519 U.S. 1033 (1996).

${ }^{173}$ Friendly, supra note 167 , at 754.

${ }^{174}$ Rosenberg, Appellate Review, supra note 167, at 180. 
type of decision is committed to the trial court's discretion in the first instance. ${ }^{175}$

Professor Rosenberg identified five rationales, or objectives, that might warrant applying the abuse-of-discretion standard in a given case: (1) conserving judicial resources by minimizing the number of issues that can be thoroughly reviewed on appeal; (2) maintaining the morale of trial courts; (3) promoting the finality of judicial decisions; (4) acknowledging the impracticality of formulating rules of decision for certain issues; and (5) committing primary responsibility for resolving certain issues to the courts best positioned to resolve them. ${ }^{176}$

As Professor Rosenberg pointed out, the first three rationales shed no light on when the abuse-of-discretion standard should apply or what its application should entail; they simply identify ends that might be achieved by frequently applying a forgiving standard of review. ${ }^{177}$ Similarly, while $§ 2254(\mathrm{~d})$ and AEDPA were prompted in large part by comparable rationales - such as a desire to reduce the number of habeas applications, to grant greater deference to state courts, and to bring a stronger sense of finality to criminal convictions ${ }^{178}$ - those rationales do not help a court determine which habeas applications should be granted or denied. The fourth rationale, while perhaps usefully identifying circumstances in which the abuse-of-discretion standard should apply, is of no analogical assistance in the habeas context because $\S 2254(d)$ 's "unreasonable application" clause applies only when "clearly established Federal law" provides the rules of decision. ${ }^{179}$

The fifth rationale, as Professor Rosenberg explained, is "the chief and most helpful reason" for committing an issue to the discretion of a trial court. ${ }^{180}$ That rationale not only helps one identify when the abuse-of-discretion standard should apply, but it also serves as a guide to ascertaining how stringently the appellate

${ }^{175}$ United States v. Criden, 648 F.2d 814, 817 (3d Cir. 1981).

${ }^{176}$ See Rosenberg, Appellate Review, supra note 167, at 181-83; Rosenberg, Judicial Discretion, supra note 166, at 660-65; see also Kunsch, supra note 166, at 35 (stating that judicial economy and allocating decision-making responsibility to the judge best positioned to decide an issue are the chief rationales underlying the abuse-of-discretion standard's application); Richard H.W. Maloy, "Standards of Review"--Just a Tip of the Icicle, 77 U. DET. MERCY L. REV. 603, 629 (2000) (stating that the abuse-of-discretion standard is applied when the trial court is best positioned to resolve the matter or has experience in resolving matters of that type or when the issue is one deemed unworthy of significant appellate attention).

${ }^{17}$ See Rosenberg, Judicial Discretion, supra note 166, at 662 (stating that the first three rationales fail "to provide clear clues as to which trial court rulings are cloaked with discretionary immunity of some strength, and which are not").

${ }^{178}$ See, e.g., 142 CONG. REC. 4595 (1996) (statement of Rep. Barr); id. at 4795 (statement of Rep. Hyde); 141 CONG. REC. 9303-05 (1995) (statement of Sen. Specter); id. at 15,062 (statement of Sen. Hatch).

${ }^{179}$ See 28 U.S.C. $\$ 2254$ (d) (Supp. II 1996). For Judge Friendly's discussion of the usefulness of the abuse-of-discretion standard in those rare instances in which there is no law to be applied, see Friendly, supra note 167, at 765-66.

${ }^{80}$ See Rosenberg, Appellate Review, supra note 167, at 183. 
court should review the trial court's ruling. ${ }^{181}$ If a matter is best resolved by a judge with direct exposure to witnesses' testimony or other aspects of the trial process, for example, that matter should probably be committed to the discretion of the trial court. The trial court's ruling on that matter, moreover, should probably be reversed only if the appellate court concludes that a reasonable judge could not agree with the trial court's ruling, regardless of what the trial court likely saw or heard first-hand in the courtroom that is not reflected in the "cold" appellate record.

Yet that rationale has only limited analytic utility for federal habeas courts charged with applying $\S 2254$ (d). Prior to AEDPA's enactment, and using the functional analysis described in Miller $v$. Fenton, ${ }^{182}$ federal courts categorically determined that state courts were not in a superior position to resolve most of the questions that federal courts routinely encounter on habeas review, such as whether an attorney provided effective assistance of counsel, whether a person was in custody at the time she was interrogated, whether a prosecutor was required to disclose potentially exculpatory evidence to a defendant, and whether the evidence presented at trial was sufficient to support a conviction. ${ }^{183}$ Because the state courts were not in a superior position to determine the merits of those claims, the federal habeas courts determined that they, the federal courts, should review those claims de novo. ${ }^{184}$ Under the AEDPA regime, however, the "unreasonably erroneous" standard applies to all applications of law to fact by state courts, including those that previously would have been reviewed de novo. Consequently, unless the federal courts are willing to change their categorical evaluation of those claims and find that, as a general rule, the state courts are indeed better positioned to resolve them, one cannot assume that each case adjudicated under $\S 2254(\mathrm{~d})$ will present dispositive issues on which the federal court will be able to distinguish meaningfully between what it can perceive in the appellate record and what the trial court might have perceived first-hand. As I argue later, there may well be particular cases in which direct exposure to the trial process places one court in a superior position to determine the merits of a claim and in which the content of the "unreasonably erroneous" standard may be illuminated accordingly; Williams, as I explain, may be just such a case. ${ }^{185}$ To the extent one wishes to draw broadly sweeping conclusions about the manner in which federal courts should distinguish between reasonably and unreasonably erroneous rulings, however, an examination of the abuse-of-discretion standard and its underlying rationales provides insufficient assistance.

\footnotetext{
${ }^{181}$ See Rosenberg, Judicial Discretion, supra note 166, at 664-65.

${ }^{182} 474$ U.S. 104, 114 (1985); see supra notes 36-40 and accompanying text.

${ }^{183}$ See supra notes 41-52 and accompanying text.

${ }^{184}$ See supra notes $41-52$ and accompanying text.

${ }^{185}$ See infra notes 306-15 and accompanying text.
} 


\section{Rule 11 Sanctions}

One particular application of the abuse-of-discretion standard warrants separate mention. Rule 11 of the Federal Rules of Civil Procedure states that, when an attorney or unrepresented party signs a document for submission to a federal district court, the person signing the document

is certifying that to the best of the person's knowledge, information, and belief, formed after an inquiry reasonable under the circumstances, ... the claims, defenses, and other legal contentions therein are warranted by existing law or by a nonfrivolous argument for the extension, modification, or reversal of existing law or the establishment of new law. ${ }^{186}$

If a court determines that a signatory has violated this rule, it may impose sanctions on the attomeys or parties responsible for the violation. ${ }^{187}$ The determination of whether the rule has been violated is "committed to the discretion of the trial court." ${ }^{, 188}$ In Cooter \& Gell v. Hartmarx Corp., ${ }^{189}$ the Court rejected the suggestion that an appellate court should more stringently review the issues raised in a Rule 11 award of sanctions than is permitted by the abuse-ofdiscretion standard. ${ }^{190}$ "Rather than mandating an inquiry into purely legal questions, such as whether the attorney's legal argument was correct," the Court observed, "the Rule requires a court to consider issues rooted in factual determinations." ${ }^{\text {"191 }}$ Specifically, the district court must consider the signatory's credibility and the circumstances in which the document was prepared. ${ }^{192}$ "[T]he district court," the Court found, "is better suited than the court of appeals to marshal the pertinent facts and apply the fact-dependent legal standard mandated by Rule 11."

Rule 11 and $\S 2254$ (d) bear a resemblance: Both are concerned with reasonable interpretations and applications of the law and both require a measure

${ }^{186}$ FED. R. CIV. P. 11(b).

${ }^{187}$ Id. at (c).

${ }^{188}$ FED. R. CIV. P. 11 advisory committee's note to 1993 amendments.

${ }^{189} 496$ U.S. 384 (1990).

${ }^{190}$ See id. at $399-405$.

${ }^{191} \mathrm{Id}$. at 401.

${ }^{192}$ Id. at 401-02; Bus. Guides, Inc. v. Chromatic Communications Enters., 498 U.S. 533, $549-51$ (1991).

${ }^{193}$ Cooter \& Gell, 496 U.S. at 402. The Court also found that "[a]n appellate court's review of whether a legal position was reasonable or plausible enough under the circumstances is unlikely to establish clear guidelines for lower courts; nor will it clarify the underlying principles of law." Id. at 405 . The Court emphasized that a district court necessarily abuses its discretion "if it based its ruling on an erroneous view of the law or on a clearly erroneous assessment of the evidence." Id. 
of tolerance for conclusions that are contrary to those that reviewing courts themselves would reach. Yet Rule 11 jurisprudence is of little help in unlocking the mysteries of $\S 2254(\mathrm{~d}){ }^{194}$ As Cooter \& Gell explains, the focus in Rule 11 is not strictly on the range of claims that were permitted by extant law, but rather on the factual question of whether the person who signed the document (1) conducted a reasonable investigation of the claim's merits and (2) believed the claim was meritorious (or at least nonfrivolous). Section 2254(d) does not merely instruct a federal habeas court to determine whether the state judge spent a reasonable amount of time researching the merits of the mixed question at issue or genuinely believed in the accuracy of her ruling; indeed, the record before a

${ }^{194}$ Neither does one other notable fee-shifting provision provide significant assistance. Under the Equal Access to Justice Act (EAJA), a person who prevails in a civil action brought by or against the United States may be awarded her "fees and other expenses" if the Government's position was not "substantially justified." 28 U.S.C. § 2412(d)(1)(A) (1994); see also Commissioner, Immigration and Naturalization Serv. v. Jean, 496 U.S. 154, 158 (1990) (summarizing the requirements for an award of fees under EAJA). In Pierce v. Underwood, 487 U.S. 552 (1988), the Supreme Court held that the Government's position is substantially justified in a particular case if it is "justified to a degree that could satisfy a reasonable person." Id. at 565 (stating, in addition, that a position is substantially justified if it has a "reasonable basis both in law and fact"). The Pierce Court further held that a district court's finding that the Government's position was or was not substantially justified is reviewed for an abuse of discretion. Id. at 559. A district court abuses its discretion if, when making or refusing an award of fees pursuant to EAJA, it relies on improper legal standards or clearly etroneous findings of fact. See, e.g., Kerin v. United States Postal Serv., 218 F.3d 185, 188-89 (2d Cir. 2000); Friends of the Boundary Waters Wilderness v. Thomas, 53 F.3d 881, 885 (8th Cir. 1995); Perales v. Casillas, 950 F.2d 1066, 1072-73 (5th Cir. 1992). A district court also abuses its discretion if the appellate court has a "definite and firm conviction" that the district court made a "clear error of judgment" when applying the law to the facts. See, e.g., F.J. Vollmer Co. v. Magaw, 102 F.3d 591, 596 (D.C. Cir. 1996); Hanover Potato Prods., Inc. v. Shalala, 989 F.2d 123, 127 (3d Cir. 1993); De Allende v. Baker, 891 F.2d 7, 11 n.7 (1st Cir. 1989).

Examining EAJA and the cases construing it does little to illuminate the manner in which reasonably and unreasonably erroneous applications of federal law should be distinguished. First, the courts have not yet managed to attach concrete meaning to the amorphous terms and phrases (such as "reasonable" and "clear error of judgment") on which EAJA jurisprudence rests. Second, to the extent that appellate rulings on EAJA turn upon a "definite and firm conviction" formulation, they are inapt points of comparison for the same reasons that cases applying the "clearly erroneous" standard of review are inapt points of comparison. See supra notes 141-65 and accompanying text. Third, in his opinion for the Court in Pierce, Justice Scalia emphasized that one of the reasons EAJA rulings should be reviewed for an abuse of discretion is that "the question whether the Government's litigating position has been 'substantially justified' is ... a multifarious and novel question, little susceptible, for the time being at least, of useful generalization." Pierce, 487 U.S. at 562 (citing Rosenberg, Judicial Discretion, supra note 166, at 662-63, for the proposition that the abuse-of-discretion standard is appropriately applied when it is difficult to frame rules of decision for the matters at hand). Federal habeas courts, in contrast, may not shift to another tribunal the primary burden of applying the "unreasonably erroneous" standard prescribed by $\$ 2254$ (d). 
federal habeas court typically does not even contain the information necessary to make such determinations. While the "unreasonable application" analysis might be affected by a state judge's apparent failure to research the law or to issue a ruling that even she finds credible, ${ }^{195}$ a federal habeas court presumably must make broader inquiries when determining whether the state court ruling itself was objectively reasonable. ${ }^{196}$

\section{Judicial Deference to Agencies' Interpretations of Ambiguous Statutes}

In Chevron U.S.A., Inc. v. Natural Resources Defense Council, Inc. ${ }^{197}$ the Court held that, when Congress has charged an agency with administering a statute and a court is then asked to review that agency's interpretation of the statute, the court must ask two questions. First, it must determine "whether Congress has directly spoken to the precise question at issue." "198 If Congress has clearly manifested its intent on the matter, the court must enforce that intent, regardless of the agency's own conclusions. ${ }^{199}$ Second, if Congress has not clearly manifested its intent on the issue in question, the court must determine whether the agency's interpretation of the statute is a "permissible" one. ${ }^{200}$ To find that an interpretation is "permissible," the reviewing court "need not conclude that the agency construction was the only one it permissibly could have adopted ..., or even the reading the court would have reached if the question initially had arisen in a judicial proceeding." 201 The court must simply respect Congress's delegation of power and defer to the agency's construction of the statute so long as it "'represents a reasonable accommodation of conflicting policies that were committed to the agency's care by the statute.",202

Chevron and Williams plainly strike a common theme: In both instances, the

${ }^{195}$ Cf. Piaskowski v. Casperson, 126 F. Supp. 2d 1149, 1159 (E.D. Wis. 2001) ("Section 2254(d)(1) requires this court to take into account the care with which the state court considered the subject.... [A] responsible, thoughtful answer reached after a full opportunity to litigate is adequate to support the judgment.") (intemal quotations and citation omitted).

${ }^{196}$ See 28 U.S.C. $\$ 2254$ (d) (Supp. II 1996) (focusing on the final product of the state court's work by stating that habeas relief is permitted if the state court's "decision" entailed an "unreasonable application of federal law"). As my discussion of conventionalism at notes 24365 indicates, however, a state court's adherence to professional norms of behavior certainly may be relevant to the analysis.

197467 U.S. 837 (1984).

${ }^{198}$ Id. at 842.

${ }^{199}$ Id. at 842-43; see also id. at $843 \mathrm{n} .9$ ("The judiciary is the final authority on issues of statutory construction and must reject administrative constructions which are contrary to clear congressional intent.").

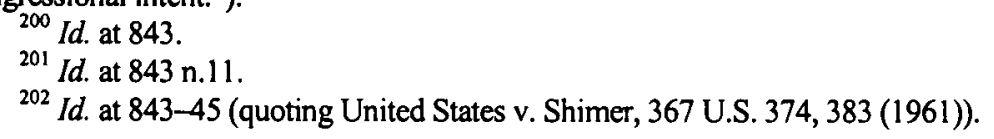


Court has recognized that federal law sometimes may reasonably be interpreted in conflicting ways and that the federal courts should sometimes refuse to disturb interpretations that they find objectionable. Yet a study of Chevron deference does not yield satisfactory insights concerning how one should distinguish between reasonably and unreasonably erroneous applications of Supreme Court precedent. First, the tasks mandated by Chevron and $\S 2254(\mathrm{~d})$ are dissimilar. Chevron concerns the interpretation of federal statutes. When determining whether an agency has interpreted federal legislation in a permissible way, a court employs the familiar tools of statutory construction, considering such things as the plain meaning of the statutory text, the relationship of one word in a clause to another, and Congress's intent in enacting the legislation. ${ }^{203}$ As every attorney knows, interpreting Supreme Court cases is an entirely different enterprise, employing different analytic tools.

Second, to the extent that the scope of Chevron deference is determined by its underlying rationales, those rationales have virtually no explanatory power in the context of federal habeas proceedings. Chevron recognizes that an administrative agency often serves "as a congressional proxy; Congress develops the statutory framework and directs the agency to flesh out the operational details." ${ }^{\text {,204 }}$ When an agency reasonably interprets a statute that it administers, a court will defer to that interpretation because the agency has special expertise in the given area ${ }^{205}$ and is better able to determine whether a given act or practice furthers or frustrates the statute's purposes. ${ }^{206}$ Additionally, a court will defer to the agency's interpretation because Congress has chosen to rely on the agency to serve a legislative, policymaking function by filling in the statute's gaps. ${ }^{207}$ In the habeas setting, however, state courts have no special expertise in discerning the dictates of Supreme Court precedent, ${ }^{208}$ nor have they been specially charged with the duty of elaborating on

${ }^{203}$ See, e.g., Young v. Cmty. Nutrition Inst., 476 U.S. 974, 980-84 (1986) (examining the Food and Drug Administration's interpretation of an ambiguous statute and discussing such things as whether one statutory phrase could reasonably be interpreted to modify another, whether the statute's legislative history revealed an intent contrary to the FDA's interpretation, and whether the FDA's interpretation rendered any other provision of the statute superfluous).

${ }^{204}$ Atchison, Topeka, and Santa Fe Ry. Co. v. Pena, 44 F.3d 437, 441-42 (7th Cir. 1994), aff'd sub nom. Brotherhood of Locomotive Eng'rs v. Atchison, Topeka, \& Santa Fe R.R. Co., 516 U.S. 152 (1996).

${ }^{205}$ See Pension Benefit Guar. Corp. v. LTV Corp., 496 U.S. 633, 651-52 (1990) ("[P]ractical agency expertise is one of the principal justifications behind Chevron deference.").

${ }^{206}$ See ICC v. Mr. B's Services, Ltd., 934 F.2d 117, 121 (7th Cir. 1991).

${ }^{207}$ See Chevron, 467 U.S. at 843 (citing Morton v. Ruiz, 415 U.S. 199, 231 (1974)); NLRB v. Bell Aerospace Co., 416 U.S. 267, 292-95 (1974); American Airlines, Inc. v. DOT, 202 F.3d 788, 797 (5th Cir.), cert. denied, 530 U.S. 1294 (2000).

${ }^{208}$ See Van Tran v. Lindsey, 212 F.3d 1143, 1152 (9th Cir.) ("Obviously, the state courts do not have special competence with respect to questions of federal law."), cert. denied, 531 U.S. 944 (2000). 
the policies embodied in the constitutional texts on which habeas applicants rely. ${ }^{209}$ An understanding of Chevron and the rationales on which it is based, therefore, bears little fruit in one's effort to learn how to distinguish between reasonably and unreasonably erroneous applications of Supreme Court precedent.

If we are fully to make sense of the "unreasonably erroneous" standard of review, therefore, we must venture into uncharted territory. Section 2254(d) appears unique in its demand that one court evaluate the quality of another court's legal reasoning on a broad range of mixed questions-regardless of the predominance of factual matters in those questions-and separate incorrect rulings on those questions into two categories, the objectively reasonable and the objectively unreasonable.

\section{THE SEARCH FOR A THEORETICAL FRAMEWORK}

Where are federal courts to look for normative guidance when trying to determine whether a state court has unreasonably applied Supreme Court precedent? Perhaps a federal court should simply identify as many cases as possible in which other courts have been confronted with materially indistinguishable facts and then determine whether the state court ruling under review falls well within the range of what other courts have done in such cases or instead falls far out on the tails of the distribution. While a distributional analysis might play a role in the new habeas regime, it surely is not sufficient: It presumes that federal courts will always be able to identify numerous materially indistinguishable cases and begs what often is the question by presuming that federal courts are able to identify those cases that are indeed materially indistinguishable.

How, then, are federal courts to apply the new "unreasonably erroneous" standard? Ideally, a court asked to apply that standard would have a clear understanding of how state courts ought to apply federal law to fact—would have, that is, a robust theory of adjudication. A theory of adjudication concerns the application of legal directives to historical facts. ${ }^{210}$ Such theories are generally

${ }^{209}$ See Williams v. Taylor, 529 U.S. 362, 387 n.13 (2000) (opinion of Stevens, J.) (stating that Cherron deference "“depends on delegation"" and that "'Congress did not delegate either interpretive or executive power to the state courts") (quoting Lindh v. Murphy, 96 F.3d 856, 868 (7th Cir. 1996), rev'd on other grounds, 521 U.S. 320 (1997)). Professor Yackle states:

In the habeas context, ... Congress is not in a position to delegate law-making authority to state courts and, then, to effectuate that delegation by instructing the federal courts to accept state court decisions. There is no federal nonconstitutional law to be made in these cases-which turn, of course, on federal constitutional law.

Yackle, Primer, supra note 90, at 445.

${ }^{210}$ See Michael S. Moore, The Semantics of Judging, 54 S. CAL. L. REV. 151, 153-55

(1981) (stating, in addition, that any plausible theory of adjudication must both give an account 
thought to serve both descriptive and normative functions. ${ }^{211}$ Brian Leiter explains:

[A] theory of adjudication makes explicit the rules that govern and explain judicial decisions. Such rules, then, are both descriptive of, and normative for, proper decisionmaking.... These rules describe the explicit decision procedure judges generally follow, and they define the explicit decision procedure that judges ought to follow more consciously and regularly. ${ }^{212}$

The problem is that the federal courts today do not possess such a theory. In the wake of formalism's rejection in the early twentieth century, it has proven to be remarkably difficult to state-either as a descriptive or as a normative matter-what it is that courts $d o$ when they apply law to fact. Yet in the absence of a satisfactory theory of adjudication, it is exceedingly difficult to discern how one might apply the "unreasonably erroneous" standard in a persuasively principled manner in all cases.

In this section, after arguing that the "unreasonably erroneous" standard rests upon a rejection of the polar extremes of formalism and radical skepticism, I consider the analytic assistance that might be provided to federal habeas courts by conventionalism, a theory of adjudication that has enjoyed increasing support over the past twenty years and that purports to provide a non-formalistic means of objectively assessing the quality of legal reasoning. ${ }^{213}$ Conventionalism is not the only candidate for providing federal habeas courts with a theoretical framework

of the meanings of words appearing in legal directives and state how close judges may come to deductive certainty in their application of those directives to historical facts); $c f$. RONALD DWORKIN, TAKING RIGHTS SERIOUSLY viii (1977) [hereinafter DwORKIN, TAKING RIGHTS SERIOUSLY] (stating that a theory of adjudication "must contain a theory of controversy, which sets out standards that judges should use to decide hard cases at law, and a theory of jurisdiction, which explains why and when judges, rather than other groups or institutions, should make the decisions required by the theory of controversy').

${ }^{211}$ Brian Leiter, Heidegger and the Theory of Adjudication, 106 YALE L.J. 253, 255 (1996); see also id. at 257 (arguing that legal philosophers assume that a theory of adjudication can serve both functions because they presume "that current adjudicative practice is roughly right").

${ }^{212}$ Id. at 258. See generally Franklin G. Snyder, Nomos, Narrative, and Adjudication: Toward a Jurisgenetic Theory of Law, 40 WM. \& MARY L. REV. 1623, 1644-54 (1999) (providing brief descriptions of the adjudicative theories of such scholars as Hans Kelsen, H.L.A. Hart, Joseph Raz, Ronald Dworkin, and adherents of Critical Legal Studies).

${ }^{213}$ See, e.g., Jay Feinman, The Jurisprudence of Classification, 41 STAN. L. REV. 661, 694 (1989) ("While formal legal reasoning has been thoroughly debunked and widely abandoned, at least in the jurisprudential literature, conventional legal reasoning has become more popular recently in the defense of neoclassical law.'); Richard A. Posner, The Jurisprudence of Skepticism, 86 MICH. L. REV. 827, 886 (1988) ("Today's anti-skeptics in law are more likely to be conventionalists than formalists."). 
within which to apply the "unreasonably erroneous" standard. ${ }^{214}$ The writings of Ronald Dworkin, for example, provide another. ${ }^{215}$ But because conventionalism and $\S 2254$ (d) strike common themes, a discussion of conventionalism's strengths and weaknesses reveals the challenges that any theory of adjudication must confront if it is to help a court distinguish between reasonably and unreasonably erroneous applications of law to fact. The discussion thereby also highlights the tremendous challenges that federal habeas courts now face.

${ }^{214}$ Another candidate, for example, is the theory of adjudication proposed in Michael S. Moore, A Natural Law Theory of Interpretation, 58 S. CAL. L. REV. 277 (1985).

${ }^{215}$ See generally RONALD DWORKIN, LAW'S EMPIRE (1986) [hereinafter DWORKIN, LAW'S EMPIRE]; DWORKIN, TAKING RIGHTS SERIOUSLY, supra note 210. Professor Dworkin contends that, in civil cases (of which habeas proceedings are a peculiar type), judicial decisions "characteristically are and should be generated by principle." DWORKIN, TAKING RIGHTS SERIOUSLY, supra note 210, at 84. By "principle," Dworkin means to refer to "a standard that is to be observed, not because it will advance or secure an economic, political, or social situation deemed desirable, but because it is a requirement of justice or faimess or some other dimension of morality." Id. at 22. With respect to constitutional adjudication in particular, Dworkin argues:

The difficult clauses of the Bill of Rights, like the due process and equal protection clauses, must be understood as appealing to moral concepts rather than laying down particular conceptions; therefore a court that undertakes the burden of applying these clauses fully' as law must be an activist court, in the sense that it must be prepared to frame and answer questions of political morality.

Id. at 147. A full discussion of the possible relationship between Dworkinian theory and the "unreasonably erroneous" standard must be reserved for another day. The person taking on that task, however, will face at least two challenges. First, she will have to persuade federal habeas courts to set aside any reservations they might have about expressly applying a theory that places moral determinations at the center of the prescribed analysis. That reluctance may explain, in part, the striking disparity between the number of citations to TAKING RIGHTS SERIOUSLY in federal courts' opinions (of which Lexis reflected approximately two dozen in February 2002) and the number of citations to that important work in law review articles (of which Lexis reflected approximately 2,000 in February 2002). Second, and more fundamentally, she will have to reconcile (1) $\S 2254$ (d)'s presupposition that there may be a range of acceptable answers to many legal questions, see infra note 233 and accompanying text, and (2) Dworkin's contention that there is a single correct answer to most legal questions. See DWORKIN, TAKING RIGHTS SERIOUSLY, supra note 210, at 279 ("My arguments suppose that there is often a single right answer to complex questions of law and political morality."). Although Dworkin acknowledges that judges may vary in their confidence that a particular ruling is correct, and although he concludes that there occasionally may be a "tie" between two competing alternative outcomes in a case, he insists that, in the great majority of cases, only one outcome is correct. Id. at 284-90. At first blush, therefore, it is difficult to see how Dworkin's theory could help a federal habeas court distinguish between reasonably and unreasonably incorrect applications of federal law. 


\section{A. The Demise of Formalism and the Challenge of Skepticism}

"Formalism" means different things to different people in different contexts. ${ }^{216}$ As I use the term here, I intend to refer to the theory that posits that, in many (if not all) legal disputes, a single, correct outcome may be logically deduced from premises setting forth unambiguous legal rules, relevant historical facts, and propositions concerning the relationship between those rules and facts. ${ }^{217}$ When attempting to discern the law's demands, formalism asserts, a

${ }^{216}$ See Richard A. Posner, Legal Formalism, Legal Realism, and the Interpretation of Statutes and the Constitution, 37 CASE W. RES. L. REV. 179, 180 (1986-87) (stating that the term "formalism" has "accreted so many meanings and valences" that it "has become an allpurpose term both of approbation and disapprobation"); Frederick Schauer, Formalism, 97 YALE L.J. 509, 510 (1988) (acknowledging that there are many uses of the word "formalism" and asserting that at the core of many of those uses "lies the concept of decisionmaking according to rule"); see also Thomas C. Grey, Langdell's Orthodoxy, 45 U. PITT. L. REV. 1, 9 (1983) ("'Formalism' describes legal theories that stress the importance of rationally uncontroversial reasoning in legal decision, whether from highly particular rules or quite abstract principles."). For a sample of the varieties of formalism and formalist legal theory, see Symposium: Formalism Revisited, 66 U. CHI. L. REV. 527 (1999) (presenting nineteen separate articles-by Richard Epstein, William Eskridge, Daniel Farber, Leo Katz, Frank Michelman, Cass Sunstein, and others - on issues relating to formalism).

${ }^{217}$ See STEVEN J. BURTON, AN INTRODUCTION TO LAW AND LEGAL REASONING 3 (2d ed. 1995) [hereinafter BURTON, INTRODUCTION] (stating that formalists insist "that legal reasoning should determine all specific actions required by the law based only on objective facts, unambiguous rules, and logic'); MORTON HORWITZ, THE TRANSFORMATION OF AMERICAN LAW, 1870-1960: THE CRISIS OF LEGAL ORTHODOXY 199 (1992) (stating that late-nineteenthcentury formalists "sought to represent legal reasoning as fundamentally different from political or moral reasoning" and "aspir[ed] to be able to render one right answer to any legal question"); Moore, supra note 210, at 155-57 (explaining that a formalist judge believes he may logically deduce a single correct answer "in at least some, if not all, cases," based solely upon the applicable legal directives and the facts); Richard H. Pildes, Forms of Formalism, 66 U. CHI. L. REV. 607, 608-09 (1999) (defining "classical formalism" as a theory of adjudication that posits, inter alia, that law is a "scientific system of rules and institutions" that provides correct answers in all cases, that rests upon "the autonomous, logical working out of the system," and that permits "ground-level rules [to] be derived from a few fundamental principles"); Posner, supra note 216, at 181 (defining formalism as "the use of deductive logic to derive the outcome of a case from premises accepted as authoritative" so that a commentator may "pronounce the outcome of the case as being correct or incorrect, in approximately the same way that the solution to a mathematical problem can be pronounced correct or incorrect"). Consider, for example, the following oft-quoted example of formalistic thinking:

Every judicial act resulting in a judgment consists of a pure deduction. The figure of its reasoning is the stating of a rule applicable to certain facts, a finding that the facts of the particular case are those certain facts and the application of the rule is a logical necessity. The old syllogism, "All men are mortal, Socrates is a man, therefore he is mortal," states the exact form of a judicial judgment. 
judge need not concern herself with the broad social purposes underlying legal directives or with the desirability of securing one outcome rather than another. ${ }^{218}$ Neither need she exercise judgment or discretion. ${ }^{219}$ Instead, formalism contends that judges work with "an extremely limited set of materials"-legal rules and historical facts-and that the "right" answer to a mixed question of law and fact can be ascertained as a matter of logical deduction. ${ }^{220}$

Consider, for example, a criminal defendant who claims that his confession of guilt should not be admitted into evidence because it was coerced. Formalism would cast the defendant's claim in terms comparable to the following:

1. If a criminal defendant's will was overborne by state actors, resulting in a confession of guilt, the defendant's confession shall not be admitted as evidence against him.

2. In the case of Defendant $\mathrm{X}$, state actors engaged in conduct $\mathrm{A}, \mathrm{B}$, and $\mathrm{C}$.

3. As a result of state actors' performance of conduct $\mathrm{A}, \mathrm{B}$, and $\mathrm{C}$, Defendant $X$ 's will was overborne, resulting in a confession of guilt.

$\therefore$ Defendant $\mathrm{X}$ 's confession shall not be admitted as evidence against him.

The first premise is supplied by a rule of law that describes the legal consequences that should flow from the occurrence of a particular set of facts. ${ }^{221}$ The second premise contains the defendant's assertion of the relevant historical

John M. Zane, German Legal Philosophy, 16 MiCH. L. REV. 287, 338 (1918). The fact that this passage is often quoted as an example of formalistic thinking is a symptom of the fact that thoroughgoing adherents to formalism are difficult to find. See DWORKIN, TAKING RIGHTS SERIOUSLY, supra note 210, at 15-16 ("So far [nominalists] have had little luck in caging and exhibiting mechanical jurisprudents (all specimens captured - even Blackstone and Joseph Beale-have had to be released after careful reading of their texts.)"); ANTHONY J. SEBOK, LEGAL POSITIVISM IN AMERICAN JURISPRUDENCE 83-112 (1998) (arguing that neither Christopher Langdell nor Joseph Beale - two scholars often associated with formalismsubscribed to all of formalism's tenets). Nevertheless, "formalistic" has long been deemed an apt characterization of a particular conception of legal reasoning that was more broadly accepted a century ago than it is today.

${ }^{218}$ See Larry Alexander, "With Me, It's All er Nuthin"': Formalism in Law and Morality, 66 U. CHI. L. REV. 530, 531 (1999).

${ }^{219}$ See David Millon, Objectivity and Democracy, 67 N.Y.U. L. REV. 1, 2-3 (1992) (stating that formalism posits that legal rules yield determinate answers to questions and that "the various extensions (or concrete applications) of a rule are immanent in the rule itself; one need not exercise discretion or judgment in order to understand the scope of a rule's applicability"); Schauer, supra note 216, at 511-13 (stating that a court's ruling is pejoratively called "formalistic" when it attempts to mask the exercise of judicial discretion with a claim that the ruling was compelled by the meaning of the terms appearing in the applicable legal directives).

${ }^{220}$ Moore, supra note 210, at 155-56.

${ }^{221}$ See Arizona v. Fulminante, 499 U.S. 279, 287-88 (1991); Schneckloth v. Bustamonte, 412 U.S. 218, 225-26 (1973). 
facts. The third premise links those historical facts with the terms of the applicable legal rule. Provided each of those premises is proven to be true, the proper resolution of the defendant's claim follows as a matter of logical deduction: Evidence of the confession must be suppressed.

Despite its continuing influence on the way attorneys cast their clients' claims and judges often purport to adjudicate those claims, ${ }^{222}$ formalism has long been rejected as a satisfactory theory of adjudication. ${ }^{223}$ One of formalism's chief defects is revealed in the third of the three premises set forth above. The terms employed in a legal directive will sometimes (if not always) be stated at too high a level of generality to permit a judge to be absolutely certain that those terms encompass the particular facts in a given case. ${ }^{224}$ To accept the third premise in

${ }^{222}$ See Moore, supra note 210 , at 166 (asserting that formalism continues to appear in modern scholarship and in courts' rulings because "it is, prima facie, the theory of adjudication required by our ideals about the rule of law"); see also id. at 155 (identifying as our rule-of-law ideals (1) that only legislatures should make law; (2) that like cases should be treated alike; and (3) that persons subject to the law's penalties should be given notice of the law's requirements); cf. KENNEDY, supra note 34, at 2 (stating that judges write their opinions in a manner intended to suggest "the legal necessity of their solutions without regard to ideology"); Posner, supra note 213 , at 887 (stating that a judge might "employ a formalist rhetoric (as an aspect of his traditionalism), but if he knows what he is about he will harbor no formalist illusions"); Antonin Scalia, The Rule of Law as a Law of Rules, 56 U. CHI. L. REV. 1175, 1185 (1989) (stating that articulating and applying rules "is an essential component of the judicial process").

${ }^{223}$ See Frank B. Cross, Shattering the Fragile Case for Judicial Review of Rulemaking, 85 VA. L. REV. 1243, 1257 (1999) (stating that "few today would subscribe to formalism as an apt description of the judicial role"); Edward Rubin \& Malcolm Feeley, Creating Legal Doctrine, 69 S. CAL. L. REV. 1989, 1989 (1996) (stating that "[t]he old, self-justificatory bromide that judges do not make the law, but only find it, is generally rejected-even scorned-these days"); Edward L. Rubin, The Practice and Discourse of Legal Scholarship, 86 MICH. L. REV. 1835, 1855 (1988) (stating that formalism "is now essentially defunct"). Formalism's downfall does not result from its reliance on logic, per se. Any credible theory of adjudication must permit logic to play a leading role. See Michael S. Moore, The Need for a Theory of Legal Theories: Assessing Pragmatic Instrumentalism, 69 CORNELL L. REV. 988, 1003 (1984) (stating that a theory of adjudication should contain a subtheory "about logic and the place of logic in legal reasoning"); Moore, supra note 210, at 180, 292 (stating that formalism's defects concern semantics and theories of meaning, rather than logic).

${ }^{224}$ See BURTON, INTRODUCTION, supra note 217 , at 54-58 (stating that a judge must always exercise at least some measure of discretion in determining which facts should be regarded as "important" under applicable legal rules); Moore, supra note 210, at 292 ("There is no plausible theory of meaning that allows a judge to be unoriginal in his decision in any case, for to have a decision that follows logically from its premises he must create what he cannot discover, i.e., the premise that connects the law to the facts."). H.L.A. Hart argued that, while in some cases the outcome may be "the necessary consequence of predetermined rules whose meaning is fixed and clear," this is often not the case:

[ $[\mathrm{n}$ the vast majority of cases that trouble the courts, neither statutes nor precedents in which the rules are allegedly contained allow of only one result. In most important cases 
the example above, a judge must determine what it means for a person's "will" to be "overborne" and whether conduct in the form A, B, and C resulted in such coercion in the case at bar. As the Legal Realists pointed out in the 1920s and $1930 \mathrm{~s},{ }^{225}$ formalism does not provide a satisfactory account of how judges make those determinations - those judgments - in every case and so does not provide a satisfactory account of what judges do when they apply law to fact. ${ }^{226}$

Williams and Ramdass exemplify formalism's failings. ${ }^{227}$ In Williams, no

there is always a choice. The judge has to choose between alternative meanings to be given to the words of a statute or between rival interpretations of what a precedent "amounts to." . . Legal rules may have a central core of undisputed meaning, and in some cases it may be difficult to imagine a dispute as to the meaning of a rule breaking out.... Yet all rules have a penumbra of uncertainty where the judge must choose between altematives.

H.L.A. HART, THE CONCEPT OF LAW 12 (2d ed. 1994). It is on the strength of the view that adjudication often (if not always) requires a judge to make choices that skeptics are able to argue that the law is indeterminate. See infra notes 229-31 and accompanying text.

${ }^{225}$ Numerous scholars have offered accounts of the Legal Realists' multi-pronged attack on formalism. See, e.g., Paul D. Carrington, Judicial Independence and Democratic Accountability in Highest State Courts, 61 LAW \& CONTEMP. PROBS. 79, 98-99 (1998) (describing the Legal Realists' attack on formalism's notion that judges may credibly "disavow politics"); Daniel C.K. Chow, Trashing Nihilism, 65 TUL. L. REV. 221, 247-51 (1990) (describing the Legal Realists' attack on formalism's metaphysical conception of legal reasoning "as logical deductions from a few eternal, immutable principles"); G. Edward White, The Evolution of Reasoned Elaboration: Jurisprudential Criticism and Social Change, 59 VA. L. REV. 279, 281 (1973) (describing Karl Llewellyn's and Jerome Frank's "repudiation of formalistic, deductive logic in judicial opinions as an artificial construct employed to conceal the subjective preferences of the judge"); Steven M. Quevedo, Comment, Formalist and Instrumentalist Legal Reasoning and Legal Theory, 73 CAL. L. REV. 119, 121-25 (1985) (describing the Legal Realists' attack on formalism's "excessive deductivism"). But cf. NEIL DUXBURY, PATTERNS OF AMERICAN JURISPRUDENCE 10 (1995) (asserting that "the commonly accepted idea of a 'revolt against formalism' in late nineteenth-century American intellectual life is, certainly so far as jurisprudence is concerned, a myth" and that " $[t]$ he great protorealist champions of anti-formalism ... were, on many jurisprudential issues, resolute formalists").

${ }^{226}$ Cf. Monaghan, supra note 35, at 236 ("If all legal propositions could be formulated in great detail, [courts' law-application] function would be rather mechanical and require no distinctive consideration. But such is not the case. Linking the rule to the conduct is a complex psychological process, one that often involves judgment."); Posner, supra note 216, at 182 (noting that formalism provides an account of how one should apply logic to premises, but gives no credible account of how the premises themselves are formed). Assessing analogical arguments is similarly daunting. See BURTON, INTRODUCTION, supra note 217 , at 25-41 (discussing analogical legal arguments and concluding that judges must make a judgment about whether similarities and differences between two or more cases are important). See generally Scott Brewer, Exemplary Reasoning: Semantics, Pragmatics, and the Rational Force of Legal Argument by Analogy, 109 HARV. L. REV. 925 (1996) (discussing the form and rational force of analogical arguments).

${ }^{227}$ See supra notes 95-133 and accompanying text (discussing Williams and Ramdass); see also Francis S. v. Stone, 221 F.3d 100, 110 (2d Cir. 2000) ("What elevate[d the Virginia 
piece of deductive reasoning makes it clear whether the Virginia Supreme Court reached an incorrect or unreasonable conclusion when it found that, even if the sentencing jury had heard all of Williams's mitigating evidence, it would have recommended that Williams be executed. Lurking beneath the Virginia court's analysis is a deductive argument, a premise of which asserts that, when the evidence of aggravating factors is what it was proven to be in Williams's case, there is no "reasonable probability" that a jury would refrain from recommending a sentence of death if it heard all of the available mitigating evidence. ${ }^{228}$ In the eyes of six Justices, that premise was objectively unreasonable; three other Justices deemed it reasonable. Formalism cannot tell us which group of Justices had the better argument. Similarly, in Ramdass, no piece of deductive reasoning can tell us whether the Virginia court sensibly could have applied the Simmons rule. Five Justices thought Simmons would be unworkable in the proposed new factual setting; four Justices believed Simmons already governed in that factual setting. There are no broadly accepted, unambiguous premises that can be plugged into a deductive argument to settle the difference of opinion.

Recognizing formalism's defects, skeptics have swung to the opposite extreme and argued that the law is either largely or entirely indeterminate and that, when purporting to apply law to fact, judges are doing no more than expressing their own preferences and biases, albeit often concealed in the guise of formalistic language. ${ }^{229}$ On this view, there is no objective method of legal reasoning that can be used to distinguish between proper and improper legal

Supreme Court's erroneous ruling in Williams] from 'merely erroneous' to 'objectively unreasonable' is difficult to learn.").

${ }^{228}$ Under Strickland v. Washington, 466 U.S. 668 (1984), a defendant must not only show that her attorney's performance was deficient, but that "there is a reasonable probability that, but for counsel's unprofessional errors, the result of the proceeding would have been different." Id. at 694 .

${ }^{229}$ See, e.g., Roberto M. UNGER, The CRITICAL Legal StUdies MOVEMENT 2, 8-11 (1986) (attacking the thesis "that lawmaking, guided only by the looser and more inconclusive arguments suited to ideological disputes, differs fundamentally from law application"); Joseph W. Singer, The Player and the Cards: Nihilism and Legal Theory, 94 YALE L.J. 1, 5 (1984) ("Those of us associated with Critical Legal Studies believe that law is not apolitical and objective: Lawyers, judges, and scholars make highly controversial political choices, but use the ideology of legal reasoning to make our institutions appear natural and our rules appear neutral."); id. at 13-19 (arguing that law is not as determinate as traditional legal theorists claim); Steven L. Winter, Indeterminacy and Incommensurability in Constitutional Law, 78 CAL. L. REV. 1443, 1448 (1990) ("The indeterminacy critique seeks to unmask legal doctrine for the social construction that it is. The critique assumes that, in the absence of a formalist view of language as an acontextual reference to objective reality, law can only function as a cover for politics."); see also Ken Kress, Legal Indeterminacy, 77 CAL. L. REV. 283, 283 (1989) ("[L]aw is indeterminate to the extent that authoritative legal materials and methods permit multiple outcomes to lawsuits."). 
reasoning. ${ }^{230}$ Rather, traditional legal reasoning has largely been employed as "a mechanism for creating and legitimating configurations of economic and political power.",231

Not surprisingly, federal judges have not been eager to concede that they are members of an oppressive elite or that their rulings are the unprincipled expressions of personal preferences. For what it is worth, the Court has acknowledged that its "legitimacy depends on making legally principled decisions under circumstances in which their principled character is sufficiently plausible to be accepted by the Nation." ${ }^{, 232}$ Of interest here, however, are $§ 2254(\mathrm{~d})$ 's implicit rejection of both formalism and skepticism and the resulting need for a theory of adjudication that occupies an acceptable middle ground between the two.

\section{B. Section 2254(d)'s Rejection of Formalism and Skepticism}

Section 2254(d)'s "unreasonably erroneous" standard rejects both naïve formalism and radical skepticism. Sailing wholly under the power of deterministic logic and a belief that unambiguous legal rules are discoverable and articulable, formalism purports to yield a single correct answer to any given legal question. By its very terms, however, the "unreasonably erroneous" standard presupposes that there may be a range of possible answers to a given mixed question, some of them unreasonable and some of them reasonable, even if incorrect. $^{233}$ By distinguishing between reasonably and unreasonably erroneous rulings, the standard thus rests upon an assumption that state courts' rulings may be evaluated under criteria broader than those formalism purports to apply.

The "unreasonably erroneous" standard also rests upon a rejection of

${ }^{230}$ See Singer, supra note 229 , at 30-38; see also id. at 51 ("Legal reasoning, as I understand it, consists of conversation. Legal reasoning is not an accurate representation of natural rights or sovereign commands. It is not the expression of an innate antecedently existing decision procedure of rational consensus that unites all persons involved in legal discourse.").

${ }^{231}$ Id. at 6; see also Snyder, supra note 212, at 1653 (stating that "the core of [Critical Legal Studies] thought is its denial that there is such a thing as legal reasoning apart from political or ethical reasoning, except at a tactical level"); Gerald B. Wetlaufer, Systems of Belief in Modern American Law: A View from Century's End, 49 AM. U. L. REV. 1, 48-59 (1999) (providing an overview of critical theory and citations to a generous supply of representative scholarly works).

${ }^{232}$ Planned Parenthood of Southeastern Pa. v. Casey, 505 U.S. 833, 866 (1992).

${ }^{233}$ Ironically, by the same logic one must conclude that there may not be a single correct answer to the question of whether a state court's ruling on a mixed question was objectively unreasonable within the meaning of $\S 2254$ (d). See infra text preceding note 286; see also Pierre Schlag, Contradiction and Denial, 87 MICH. L. REv. 1216, 1223 (1989) (reviewing MARK KELMAN, A GuIDE to CRTICAL LEGAL STUDIES (1987)) ("[S]tandard legal thought greatly underestimates the extent to which its discourses are intemally contradictory, incommensurable, and paradoxical."). 
skepticism. Skepticism denies that there is any objective basis for evaluating the reasonableness of a court's application of law to fact and instead asserts that a court's rulings are a function of that judge's subjective preferences. Section 2254(d), however, presupposes that legal reasoning may be evaluated under criteria that transcend the preferences of any single jurist. The Williams Court stressed that a federal habeas court cannot base its reasonableness determination "on the simple fact that at least one of the Nation's jurists has applied the relevant federal law in the same manner the state court did in the habeas petitioner's case. ${ }^{234}$ This does not mean that $\$ 2254$ (d) necessarily rests upon an antiquated, Platonic notion of objective truths. ${ }^{235}$ It does mean, however, that a federal court must base its ruling on something other than the fact that at least one other seemingly reasonable judge has endorsed the state court's reasoning. ${ }^{236}$

In its rejection of both formalism and skepticism, § 2254(d) appears to seek a balance that resonates with the experience of many legal professionals. An attomey working in the litigation trenches quickly learns that law is not as determinate as formalism would have one believe. As skeptics have pointed out, legal directives often are ambiguous and credible arguments often may be marshaled to reach conflicting conclusions. ${ }^{237}$ At the same time, however, every litigator has experienced the disappointment that comes from spending an afternoon in the library and learning that one's client "does not have a case" or that legal authorities appear to foreclose arguments that one had hoped to make. ${ }^{238}$ The law often has an undeniable elastic quality, in other words, but there are limits on how far it may be stretched. The more experience an attorney acquires, the more fine-tuned her ability becomes to distinguish between arguments that other professionals might find persuasive and arguments that

${ }^{234}$ Williams v. Taylor, 529 U.S. 362, 409-10 (2000).

${ }^{235}$ Cf. DWORKIN, TAKING RIGHTS SERIOUSLY, supra note 210, at 15 (rejecting the notion that law consists of "a set of timeless rules stocked in some conceptual warehouse awaiting discovery by judges").

${ }^{236}$ David Millon's notion of "intellectual structures that exist intersubjectively" might bear fruit in trying to conceptualize the Court's notion of objectivity. See Millon, supra note 219, at 33 ; infra note 252 and accompanying text (quoting the relevant passage from Millon); see also infra notes 243-84 (discussing conventionalism).

${ }^{237}$ See, e.g., UNGER, supra note 229 , at 8 ("'E]very thoughtful law student or lawyer has had the disquieting sense of being able to argue too well or too easily for too many conflicting solutions."); see also Richard K. Greenstein, The Nature of Legal Argument: The Personal Jurisdiction Paradigm, 38 HASTINGS L.J. 855, 855 (1987) ("We know that legal doctrine is often indeterminate - that in a particular case, perfectly convincing arguments supporting one conclusion can often be countered by perfectly convincing arguments supporting the opposite conclusion.").

${ }^{238}$ Cf. David Millon, Theories of the Corporation, 1990 DUKE L.J. 201, 245 (stating that, notwithstanding the indeterminacy critique, lawyers and judges regularly experience "interpretive constraints"). 
surely will fail. She probably cannot fully articulate the rationale she uses to separate one from the other, but she often can separate them nonetheless. ${ }^{239}$

Although the "unreasonably erroneous" standard is consistent with legal professionals' experience of the law as at least moderately indeterminate but nevertheless frequently predictable, we should not be surprised to find the lower federal courts expressing alarm about the new task with which they have been charged. $^{240}$ Section 2254 (d) implicitly discredits those courts that continue to engage in the time-honored practice of cloaking judgments in the deterministic language of formalism. Prior to AEDPA's enactment, a federal court asked to review a state court's resolution of a mixed question of law and fact was under no obligation, upon reviewing and rejecting the state court's ruling, to acknowledge that the state court's reasoning may have been plausible. Even if the federal judge knew that many of his colleagues on the federal bench would readily adopt the state court's reasoning as their own, he could grant habeas relief and cast his ruling in the formalistic language of right and wrong and truth and error that a de novo standard of review permits a court to employ. ${ }^{241}$ Like one famous cinematic terrier, AEDPA has now pulled back the curtain, as it were, and exposed the man behind the wizard. Most legal professionals knew that the man was there all along, exercising discretion even if the language he used often suggested logical compulsion. Now fully exposed, however, it is time for him to give a satisfactory account of his methods of legal reasoning. ${ }^{242}$

${ }^{239}$ Cf. Roscoe Pound, The Theory of Judicial Decision, 36 HARV. L. REV. 940, 951 (1923), quoted in BURTON, INTRODUCTION, supra note 217, at 91 ("The trained intuition of the judge continually leads him to right results for which he is puzzled to give unimpeachable legal reasons.").

${ }^{240}$ See supra notes 8-9 and accompanying text (noting the trepidation expressed by the Second and Ninth Circuits).

${ }^{241}$ Consider, for example, Frederick Schauer's critique of the Court's frequently maligned ruling in Lochner v. New York, 198 U.S. 45 (1905):

We condemn Lochner as formalistic not because it involves a choice, but because it attempts to describe this choice as compulsion. What strikes us clearly as a political or social or moral or economic choice is described in Lochner as definitionally incorporated within the meaning of a broad term [namely, the term "liberty" in the Fourteenth Amendment]. Thus, choice is masked by the language of linguistic inexorability.

Schauer, supra note 216, at 511-12 (citation omitted).

${ }^{242}$ Comparable concerns have been raised with respect to Teague's new-rule analysis. See, e.g., Dubber, supra note 64, at 12-20 (arguing that Teague purports to provide an objective, principled method of identifying new rules, when subjective value judgments actually play leading roles in that identification process). 


\section{Conventionalism}

\section{General Precepts}

A number of scholars have usefully proposed conventionalism-an expression of legal positivism ${ }^{243}$-as an alternative to the deterministic objectivism of formalism, on the one hand, and the indeterministic subjectivism of skepticism, on the other. ${ }^{244}$ Seeking a middle ground between those two extremes, conventionalism refuses to posit the existence of only one correct, objectively ascertainable answer to any given legal question, yet insists that judges operate within meaningful objective constraints of the sort denied by skeptics. Given $\S 2254$ (d)'s similar rejection of formalism and skepticism, conventionalism clearly offers itself as a candidate for use by judges faced with the task of applying the "unreasonably erroneous" standard.

Conventionalists contend that, when confronted with a mixed question of law and fact, "[t]he judge's choice [of outcomes] is constrained by a set of rules (or norms, standards, principles, guides, etc.) that are authorized by the professional community of which the judge is part (and that define and constitute the community)."245 As a general matter, these "conventions" consist of those practices and dispositions that "members of the legal community generally will take to be required by an orderly and just society in a case, as indicated by the legal experience and the law's purposes."246 Such conventions include, among others, "pay[ing] particular attention to the wording of a text and to the intent of the framers, ${ }^{, 247}$ selecting outcomes that achieve the law's objectives, ${ }^{248}$ justifying

${ }^{243}$ See Jules L. Coleman, Second Thoughts and Other First Impressions, in ANALYZING LAW: NEW ESSAYS IN LEGAL THEORY 257, 264 (Brian Bix ed., 1998) ("[T]he central project of legal positivism is to explain law's moral and social dimensions and the connection between them within a conventionalist framework. Positivists differ from other legal theorists by the emphasis they put on law's conventionality.").

${ }^{244}$ See BURTON, INTRODUCTION, supra note 217, at 90 (stating that conventionalists reject formalism's and skepticism's shared premise that the law must either dictate results or be deemed worthless); Millon, supra note 238, at 245 ("Conventionalists ... offer a middle ground between foundationalist and so-called nihilist accounts of legal reasoning."). Sources setting forth leading (and somewhat varying) articulations of the tenets of conventionalism include BURTON, INTRODUCTION, supra note 217; Steven J. Burton, Reaffirming Legal Reasoning: The Challenge from the Left, 36 J. LEGAL EduC. 358 (1986); and Owen M. Fiss, Conventionalism, 58 S. CAL. L. REV. 177 (1985). For a discussion of conventionalism's philosophical heritage, see Dennis M. Patterson, An Introduction to Conventionalism, 10 W. NEW ENG. L. REV. 43, 51 n.36 (1988).

${ }^{245}$ Fiss, supra note 244 , at 183 (citation omitted). Professor Fiss refers to these conventions as "disciplining rules." See id. at 184.

${ }^{246}$ BURTON, INTRODUCTION, supra note 217 , at 93, 117.

${ }^{247}$ Fiss, supra note 244 , at 183. 
outcomes with arguments relating to principles and policies, ${ }^{249}$ and paying due respect to the principles of stare decisis and legislative supremacy. ${ }^{250}$ It is because the profession adheres to and is defined by such conventions that practitioners are able to reach agreement on how a large number of legal disputes should be resolved. ${ }^{251}$ Similarly, it is because the profession employs such conventions that legal reasoning has an objective component. ${ }^{252}$

A conventionalist judge, therefore, recognizes that she is a member of an "interpretive community." commitment to the common interpretive criteria that are internal and specific to

${ }^{248}$ See BURTON, INTRODUCTION, supra note 217 , at 115.

${ }^{249}$ See id. at 110-15; Feinman, supra note 213, at 694; cf. HENRY M. HART, JR. \& ALBERT M. SACKS, THE Legal Process: Basic Problems IN THE MAKING AND APPLICATION OF LAW 158-60, 166-67 (tentative ed. 1958) (explaining that "principles" and "policies" underlie every legal directive, and arguing that judges confronted with an ambiguous legal directive should resolve that ambiguity in a manner consistent with the principles or policies that the legal directive is intended to serve).

${ }^{250}$ See BURTON, INTRODUCTION, supra note 217 , at 115 . On the conventionalist view, judges are also constrained by a desire to remain in good standing within the interpretive community. See Millon, supra note 219, at 23-27.

${ }^{251}$ See BURTON, INTRODUCTION, supra note 217, at 93-94; Millon, supra note 238, at 244-45 ("The conventionalist account responds to assertions of law's indeterminacy by attempting to give an explanation for the general (though not unrelenting) predictability of legal results ...."); cf. Singer, supra note 229, at 21-23 (discussing conventions and stating that "the choices made by judges ... are often predictable because these decisionmakers share a legal culture").

${ }^{252}$ See Fiss, supra note 244, at 183 ("Adherence to the rules authorized by the professional community imparts a measure of impersonality to a legal judgment (its objective quality) and at the same time provides the standards for evaluating the correctness of the judgment as a legal judgment."); Dennis Patterson, Normativity and Objectivity in Law, 43 WM. \& MARY L. REV. 325, 351-63 (2001) (arguing that lawyers' use of certain "forms of argument" gives the law objectivity); $c f$. Fallon \& Meltzer, supra note 64 , at 1761-62 (stating that judges must act within certain conventions and so do not exercise pure political will when making new law). David Millon writes:

Legal interpretation is subjective because it is constructed by subjects. But these interpretive activities occur within a context of intellectual structures that exist intersubjectively.... Though legal texts and doctrine are indeterminate, the profession's commitment to interpretation according to shared notions of validity rather than personal preference renders actual legal practice an objective enterprise. Objectivity is possible in spite of indeterminacy.

Millon, supra note 219, at 33; see also id. at 6-7 (stating that conventionalism "denies that the only alternative to an objectivity based on formalism is a radical, everything-is-up-for-grabs-inevery-case indeterminacy").

${ }^{253}$ See Millon, supra note 219, at 10; see also id. at $10 \mathrm{n} .22$ (tracing the notion of an interpretive community to the writings of David Bleich and Stanley Fish). 
the legal profession."254 A judge's rulings are wise or foolish, correct or incorrect, reasonable or unreasonable, depending on whether the legal profession finds those rulings acceptable in light of the criteria by which the profession interprets the law's requirements. ${ }^{255}$ That is, a judge's "[a]dherence to the rules authorized by the professional community... provides the standard for evaluating the correctness of the judgment as a legal judgment."256

Conventionalism therefore suggests that a federal habeas court charged with applying the "unreasonably erroneous" standard should determine whether the state court violated the conventions of the legal community when it rejected the prisoner's claim. Did the state court, for example, evaluate all of the evidence that bore upon the merits of the prisoner's claim? Did the state court reach a conclusion that is consistent with the law's underlying objectives? Did the state court use accepted methods of interpretation when trying to discern the meaning of the applicable legal texts? If the state court adhered to such conventions and nevertheless reached a conclusion contrary to the conclusion the federal habeas court would have reached on de novo review, conventionalism likely suggests that the state court's erroneous ruling is reasonable and so must be permitted to stand. If the state court violated the profession's conventions, however, its erroneous ruling might fall beyond the bounds of objective reasonableness and so might not pose an obstacle to federal habeas relief. ${ }^{257}$

Conventionalism provides a strong rebuttal to those who claim that law is radically indeterminate and that judges operate without meaningful, external constraints. It also provides an analytic framework that should prove useful to federal habeas courts. Indeed, while not expressly citing conventionalist theory, a number of federal courts have applied the "unreasonably erroneous" standard in ways that are conventionalist in nature. Some federal courts, for example, have sought to determine what other courts have done when presented with comparable facts, ${ }^{258}$ some have asked whether the courts have reached a

${ }^{254}$ Id. at 10; cf. Rubin, supra note 223, at 1859 (stating that judges and legal scholars "invoke the same range of justifications, ... structure these justifications the same way, .... and employ the same legal terms, and treat them with comparable levels of respect or disdain").

${ }^{255}$ See Millon, supra note 219 , at 27 ("For the judge, a correct interpretation is one that other judges and legal scholars will accept.").

${ }^{256}$ Fiss, supra note 244, at 183; see also id. at 194 (stating that "professional norms constrain judges in choosing among the conflicting interpretations and are the standards for assessing the correctness of their decisions"); Burton, supra note 244, at $365 \mathrm{n} .28$ (stating that "judges interpret [in order] to ascertain the dispositions of a group of people about what is right, not just to ascertain what really is right, objectively or in the judge's own view").

${ }^{257}$ Conventionalism does not suggest what should happen, however, when a state court adhered to all relevant conventions except one, and legal professionals do not agree on whether adherence to that single convention is essential or merely preferable.

${ }^{258}$ See, e.g., Dormire v. Wilkinson, 249 F.3d 801, 805 (8th Cir. 2001) ("Other courts have come to the same conclusion when presented with [comparable facts]."); Ellsworth v. 
consensus on how certain kinds of cases should be handled, ${ }^{259}$ some have asked whether any evidence in the record weighs against the state court's ruling, ${ }^{260}$ some have asked whether the state court examined the pertinent portions of the record, ${ }^{261}$ some have asked whether the state court even considered the petitioner's primary contentions, ${ }^{262}$ some have asked whether the state court appeared to handle the case in a careful and thoughtful manner, ${ }^{263}$ some have asked whether authorities have been cited in support of either the state court's ruling or the habeas petitioner's position, ${ }^{264}$ and some have asked whether the state court's ruling serves the law's objectives. ${ }^{265}$ In each such instance, the federal habeas court is fruitfully asking, in essence, whether the state court adhered to the profession's conventions.

Conventionalism is not, however, a fully satisfactory theory of adjudication. In hard cases, it falls short of providing an adequate measure of guidance to federal courts seeking to distinguish between reasonably and unreasonably erroneous rulings.

Levenhagen, 248 F.3d 634, 642 (7th Cir. 2001) (asking what the Seventh Circuit has done when "confronted with similar factual situations"). But see Valdez v. Ward, 219 F.3d 1222, 1230 (10th Cir. 2000) ("[T]he fact that one court or even a few courts have applied the precedent in the same manner to close facts does not make the state court decision 'reasonable."').

${ }^{259}$ See, e.g., Carter v. Kemna, 255 F.3d 589, 592 (8th Cir. 2001) (noting disagreement among the lower federal courts about whether a defendant's rights are violated if an altemate juror is wrongly stricken from the venire, but no alternate juror ever joins the deliberating jury).

${ }^{260}$ See, e.g., Parker v. Head, 244 F.3d 831, 837 (11th Cir. 2001) (noting that all of the evidence cut against the habeas petitioner's claim).

${ }^{261}$ See, e.g., Elliott v. Williams, 248 F.3d 1205, 1208 (10th Cir. 2001) (observing that, on the petitioner's ineffective-assistance-of-counsel claim, the state court had not "cit[ed] to the record indicating the Court had reviewed counsel's conduct").

${ }^{262}$ See, e.g., Hurtado v. Tucker, 245 F.3d 7, 18 (1st Cir. 2001) ("The failure of the state court to consider at all a key argument of the defendant may indicate that its conclusion is objectively unreasonable; however, the paucity of reasoning employed by the state court does not itself establish that its result is objectively unreasonable.").

${ }^{263}$ See, e.g., Simpson v. Bouker, 249 F.3d 1204, 1211 (10th Cir. 2001) (finding that the state court issued a "well-reasoned opinion" based upon a "careful examination" of the pertinent authorities); Hernandez v. Johnson, 248 F.3d 344, 375 (5th Cir. 2001) (finding that the state court's ruling was based upon "ambivalent and indeterminate conclusions").

${ }^{264}$ See, e.g., Cross v. Bruton, 249 F.3d 752, 754 (8th Cir. 2001) (stating that the petitioner had "not identified any authority that supports his claim"); Elliott, 248 F.3d at 1208 (noting that the state court's ruling contained no "citation to case law involving similar conduct or issues").

${ }^{265}$ See, e.g., Newman v. Hopkins, 247 F.3d 848, 853 (8th Cir. 2001) (finding that the state court's ruling did not serve the state interests animating the underlying substantive law). 


\section{Hard Cases}

As I use the term here, "hard cases" have one of at least two different features: the law's underlying purposes pull in opposing directions (such as in Ramdass) or the relevant conventions have been exhausted and a dispute remains concerning the merits of the applicant's claim (such as, perhaps, in Williams). ${ }^{266} \mathrm{I}$ address each in turn.

First, conventionalism does not yet provide a satisfactory account of how a judge should decide a case in which the law's purposes pull in opposing directions. ${ }^{267}$ One of the chief interpretive criteria emphasized by conventionalists is the convention favoring outcomes that achieve the law's purposes. ${ }^{268}$ Often, however, those purposes favor conflicting outcomes. In federal habeas proceedings, conflicting purposes can appear on both procedural and substantive levels. First, provided a habeas application is not patently frivolous, ${ }^{269}$ there ordinarily is a conflict between (1) respecting and securing the finality of state criminal convictions and (2) giving state prisoners an opportunity to present their federal claims to life-tenured judges with expertise in matters conceming federal law. The tension between those two sets of objectives is, of course, a tension that has long persisted in federal habeas law and that has divided so-called liberals and conservatives for years. ${ }^{270}$ Indeed, that tension is revealed in the "unreasonably erroneous" standard itself. That standard strongly endorses the values of finality

${ }^{266}$ Cf. DWORKIN, TAKING RIGHTS SERIOUSLY, supra note 210, at 81 (using the term "hard cases" to refer to cases that cannot easily and uncontroversially be adjudicated under a "clear" and "settled" rule of law); Snyder, supra note 212, at 1644 (using the term "hard cases" to refer to "any case in which different outcomes could be defended plausibly within the normal scope of legal discourse-that is, cases on which a significant number of lawyers and judges would reach different outcomes") (citation omitted).

${ }^{267}$ Professor Burton acknowledges that "harder cases are hard due to the conflicting implications of competing purposes." BURTON, INTRODUCTION, supra note 217, at 124; cf. STEVEN J. BURTON, JUDGING IN GOOD FArTH 68 n.55 (1992) (acknowledging the possibility that, "even if there is widespread agreement within the legal community on the legally correct outcome in many cases, there will be no consensus in some, including the most important litigated cases").

${ }^{268}$ See supra note 248 and accompanying text.

${ }^{269}$ Federal district courts may summarily dismiss patently frivolous habeas applications. See 28 U.S.C. $\$ 2243$ (1994); Rule 4, Rules Governing Section 2254 Cases in the United States District Courts, 28 U.S.C. $\$ 2254$ (1994).

${ }^{270}$ See generally Hoffstadt, supra note 7, at 965-1003 (discussing the competing descriptive and normative theories of federal habeas corpus that courts and scholars traditionally have advocated); Ann Woolhandler, Demodeling Habeas, 45 STAN. L. REV. 575, 582-87 (1993) (contrasting (1) the view that federal habeas should be limited to ensuring that state courts provide "a full and fair opportunity to litigate" federal constitutional claims and (2) the view that federal habeas should permit federal courts to "review de novo all issues of federal constitutional law"). 
and comity, permitting reasonably erroneous state court rulings to remain undisturbed. Yet it does not close the door entirely to the vindication of federal rights in federal court: Particularly egregious enrors need not be tolerated. When asked to determine whether a state court's erroneous ruling was unreasonable, therefore, a federal court is pulled between the desire to respect the state's interest in bringing the litigation to an end and the desire to ensure that the state has not trampled upon the applicant's federal rights.

The second level at which conflicting purposes often appear is at the level of the underlying substantive law. The law governing any given federal claim almost inevitably reflects an attempt to balance the interests of the state against the interests of the individual. The law relating to involuntary confessions, for example, reflects an attempt both to protect the dignity of the individual and to enable state officials to conduct productive interrogations.

Of course, the presence of conflicting purposes at either of those two levels would be of no practical significance if the Constitution or Congress had resolved those conflicts in unambiguous terms-a court's task would simply be to enforce those resolutions. ${ }^{271}$ But because semantic imprecision almost invariably appears both in the law of habeas proceedings and in the underlying substantive law-in terms such as "unreasonable" and "overborne," for example-federal courts are routinely called upon to exercise judgment and so must grapple with the conflicting purposes that the law reflects.

Ramdass exemplifies both levels of conflict. ${ }^{272}$ The governing substantive law, as articulated in Simmons, reflects both (1) a desire to enable a defendant to rebut a prosecutor's claim that the defendant poses a threat of future dangerousness and (2) a desire to ensure that the evidence placed before the jury genuinely does tend to undermine the prosecutor's claim. ${ }^{273}$ Because Ramdass was a habeas case, the conflicting objectives of finality, comity, and rightsvindication were also in play. Was the Virginia Supreme Court unreasonable when it refused to extend Simmons to a case in which a jury had convicted the defendant of a third felony, but judgment on that third offense had not yet been entered? A federal court's answer to that question necessarily reflects a judgment about the relative strength of each of the conflicting purposes that the question implicates.

How should a judge resolve such tensions in the law? One conventionalist scholar has suggested that, when the law governing a particular dispute reflects

${ }^{271}$ Cf. Schauer, supra note 216 , at 537 (arguing that, if rules are to retain their significance, judges must not bypass them whenever they like in favor of a consideration of the rules' underlying purposes).

${ }^{272}$ See Ramdass v. Angelone, 530 U.S. 156 (2000); supra notes 119-35 and accompanying text (discussing Ramdass).

${ }^{273}$ See Simmons v. South Carolina, 512 U.S. 154, 163-64 (1994); supra notes 123-24 and accompanying text (discussing Simmons). 
conflicting purposes, a judge should determine which of those purposes "are the stronger under the circumstances",274 and should choose the outcome that requires the fewest number of changes in the judge's convention-based "web of beliefs" about the way in which the law seeks to achieve order and justice. ${ }^{275}$ Yet as the Court's divided rulings in Williams and Ramdass illustrate, legal professionals often have competing understandings of what "order and justice" are and the ways in which the law does and should try to achieve them. The same three Justices who argued against the grant of habeas relief in Williams, for example, joined with two other Justices to deny habeas relief in Ramdass. Indeed, the Justices frequently break into fairly predictable groups on matters concerning criminal defendants' rights and the issuance of habeas relief. ${ }^{276}$ If our touchstone in applying the "unreasonably erroneous" standard is to be the profession's conventional understanding of the ways in which the law achieves order and justice, therefore, it seems that, in many cases, we won't know for sure whether the state court's ruling was objectively unreasonable until the swing votes on the Court have spoken. And, if that is true, then we have failed to give a satisfactory account of what it means for a ruling to be objectively unreasonable and we remain within the skeptics' grasp. ${ }^{277}$

\footnotetext{
${ }^{274}$ BURTON, INTRODUCTION, supra note 217, at 123.

${ }^{275}$ Id. at 124-34. Professor Burton more fully explains the latter point as follows:
}

The judge's web of beliefs about law... should include the law's conventional justifications, which are crucial for regularity and coordination. Order and justice should be at the center, where they can support the remainder of the web, which should work out the implications of those values for legal precedents, rules, principles, and policies. To have value in pursuing order and justice, a legal web of beliefs should synthesize the legal experience and the law's purposes as a coherent and valuable whole. The principles and policies that give coherence to the rules and precedents should be those accepted by the legal community as conventional justifications for the laws. The conscientious judge faced with a harder case should reach the decision that requires the fewest adjustments to maintain or enhance the coherence of the law, given the centrality of order and justice. Accordingly, a judge should prefer to abandon or modify those beliefs about law that deviate more from the conventions of the legal community.

Id. at $128-29$.

${ }^{276}$ Imagine, for example, that your client has been sentenced to death and that you must present an emergency petition to a single Justice of the United States Supreme Court. Most practitioners probably would not be indifferent about the identity of the Justice charged with reviewing the merits of the petition.

${ }^{277}$ Cf. Patterson, supra note 252, at 340-41 ("The question whether a legal standard has or has not been violated should turn on more than the caprice of who is asked to decide the matter.") A related problem concerns the issue of incommensurability. It is in large measure because values such as finality and procedural due process strike many as being incommensurate that-so long as neither the Constitution nor Congress has told us how those values relate to one another-judges sometimes find themselves unable to bridge the gaps between them and agree upon how hard cases should be decided. See T. Alexander Aleinikoff, 
With respect to the second category of hard cases, conventionalism does not provide satisfactory guidance in cases in which the relevant conventions have been exhausted and a question remains as to whether the habeas applicant satisfied his burden of proof on his federal claim. ${ }^{278}$ In these cases, the state court correctly identified the governing legal directives, examined the evidence presented in support of and against the prisoner's federal claim, and concluded that the prisoner failed to prove his claim. The federal court cannot fault the state court's adherence to the profession's conventions-the state court's ruling does not plainly frustrate the law's purposes, for example - and yet the federal court believes that the applicant satisfied his burden of proof. Because the federal court would find the claim meritorious on de novo review, the state court's ruling is erroneous-but is it unreasonable?

Setting aside the Virginia Supreme Court's erroneous articulation of the legal standard governing claims of ineffective assistance of counsel, ${ }^{279}$ the facts in Williams (perhaps with one additional modification) present just such a case. Williams argued that the evidence demonstrated a reasonable probability that the jury would not have recommended a death sentence if it had heard all of the mitigating evidence at his counsel's disposal. The six Justices of the United States Supreme Court who concluded that the Virginia court's ruling was objectively unreasonable stated that the Virginia court had "failed to evaluate the totality of the available mitigation evidence" by failing to "entertain th[e] possibility" that "[m]itigating evidence unrelated to [future] dangerousness may alter the jury's

Constitutional Law in the Age of Balancing, 96 YALE L.J. 943, 972 (1987) ("A frequent criticism of balancing [tests] is that the Court has no objective criteria for valuing or comparing the interests at stake."). Professor Aleinikoff elaborates:

[The Court's] balancing opinions are radically underwritten: interests are identified and a winner is proclaimed or a rule is announced which strikes an "appropriate" balance, but there is little discussion of the valuation standards. Some rough, intuitive scale calibrated in degrees of "importance" appears to be at work. But to a large extent, the balancing takes place inside a black box. Of course, the hidden process raises the specter of the kind of judicial decisionmaking that the Realists warned us about ....

Id. at 976; see also David L. Faigman, Madisonian Balancing: A Theory of Constitutional Adjudication, 88 Nw. U. L. REV. 641, 651-53 (1994) (attempting to defend balancing tests against such criticisms).

${ }^{278} \mathrm{~A}$ habeas applicant bears the burden of proving that his federal claim is meritorious. See, e.g., Whitaker v. Meachum, 123 F.3d 714, 716 (2d Cir. 1997) ("It is well-settled that on federal collateral review, the petitioner bears the burden of proving that his constitutional rights were violated."). Because habeas proceedings are civil in nature, the standard of proof is usually proof by a preponderance of the evidence. See LIEBMAN \& HERTZ, supra note $42, \S 31.2$; see also id. at $\$ 31.2 \mathrm{n} .4$ (explaining that proof burdens other than the familiar preponderance burden sometimes "characterize particular substantive claims for relief," such as claims of jury discrimination and of incompetence to stand trial).

${ }^{279}$ See supra note 114 and accompanying text. 
selection of penalty, even if it does not undermine or rebut the prosecution's death-eligibility case." ${ }^{280}$ If the Virginia court did indeed fail even to consider one of Williams's arguments, it likely violated one of the legal profession's conventions: The very notion of adjudication presupposes that a court will at least consider the merits of a complainant's properly presented legal arguments. ${ }^{281}$ But what if-like the three dissenting Justices in Williams-the Virginia court had considered all of Williams's arguments and found them unpersuasive? When the relevant conventions have been exhausted and the disagreement between a state court and a federal habeas court simply rests on differing views of the strength of the prisoner's evidence, how is the federal court to determine whether the state court's erroneous ruling was unreasonable? ${ }^{282}$ Jurists with comparable understandings of the law might very well disagree about whether Williams had shown a "reasonable probability" that the jury's sentencing recommendation would have been different if it had heard all of the available mitigating evidence. ${ }^{283}$ The federal habeas court, having found itself persuaded of the claim's merits, must make a judgment about the reasonableness of the state court's contrary conclusion. By what means is that judgment to be made? Conventionalism does not tell us.

Conventionalism's inadequacies reveal the profoundly difficult challenges one encounters when trying to frame a normative theory of adjudication that will enable a federal court to distinguish between reasonably and unreasonably erroneous applications of Supreme Court precedent in hard cases. Legal directives' terms are often susceptible to conflicting interpretations and reflect competing purposes, and judges sometimes disagree about the outcomes that the

${ }^{280}$ Williams v. Taylor, 529 U.S. 362, 397-98 (2000); see also id. at 398 ("But the state court failed even to mention the sole argument in mitigation that trial counsel did advance.....").

${ }^{281}$ Cf. Hurtado v. Tucker, 245 F.3d 7, 18 (1st Cir. 2001) ("The failure of the state court to consider a key argument of the defendant at all may indicate that its conclusion is objectively unreasonable ....").

${ }^{282}$ One apparently cannot say that a state court's ruling must necessarily be deemed objectively reasonable if that court adhered to all of the relevant conventions. The Williams Court granted habeas relief based largely on the fact that it was impressed by the strength of Williams's mitigating evidence; the dissenting Justices were not as impressed by that evidence and so voted against granting habeas relief. The Justices' disagreement is primarily one concerning the strength of the applicant's proof, rather than one concerning the Virginia court's adherence to the profession's conventions. See generally DWORKIN, LAW'S EMPIRE, supra note 215, at 128-29 (stating that there are cases in which conventions are exhausted without pointing clearly to a proper outcome); DWORKIN, TAKING RIGHTS SERIOUSLY, supra note 210, at 103 (stating that relevant conventions may "run out" before an adjudicator has obtained sufficient information to resolve a dispute).

${ }^{283}$ Cf. Hurtado, 245 F.3d at 18 ("The failure of a state court to give appropriate weight to all of the evidence may mean that its conclusion is objectively unreasonable."). 
law does and should require. Moreover, evidence that powerfully persuades one judge might not impress another. When state and federal judges disagree about the proper outcome of a case, we need-but do not yet have-a theory of adjudication that will help us to determine when the state judges are applying the law in a reasonable manner and when they have strayed into the forbidden territory of unreasonableness. Recognizing the daunting challenges posed in fashioning such an analytic tool, at least one scholar, writing in a non-habeas context, has entertained the possibility that we might never successfully frame a satisfactory theory of adjudication. ${ }^{284}$ Yet as Williams and Ramdass illustrate, until those challenges have been met, it will be exceedingly difficult in hard cases for federal habeas courts to execute $\S 2254(\mathrm{~d})$ 's charge.

\section{ANALYTIC TOUCHSTONES}

Suppose courts and theorists prove unable to frame a theory of adjudication that provides specific guidance on how the federal courts should apply the "unreasonably erroneous" standard in hard cases. ${ }^{285}$ Or, suppose (as it appears) that the federal courts are going to have to decide many hard cases prior to the time such a theory is conceived. Are there any analytic touchstones, short of a full-blown theory of adjudication, that might help a federal court distinguish between reasonable and unreasonable errors?

I shall propose three such touchstones here. Their normative utility, however, must be placed in proper perspective. None of these analytic tools is intended to describe the particular characteristics of reasonable or unreasonable applications of federal law. Nor are they intended to lead all reasonable jurists to the same conclusions in all cases. Just as $\S 2254$ (d) implicitly acknowledges that formalism does not give us the tools we need to discern "the" single correct answer to every legal question, so too should we not expect that any single analytic guide (or perhaps any single theory of adjudication, for that matter) will always unambiguously lead a federal court applying the "unreasonably erroneous" standard to "the" correct conclusion. The law is full of terms and standards that evade precise description and application, ${ }^{286}$ and we simply have been willing to

${ }^{284}$ See Leiter, supra note 211 , at 277 (stating that, if certain Heideggerian insights are accurate, "then there is a lot that judges are doing in deciding cases, that we, as jurisprudential theorists, cannot articulate or, consequently, cannot subject to critical evaluation").

${ }^{285}$ See supra notes $266-84$ and accompanying text (discussing the challenges posed in hard cases).

${ }^{286}$ Frederick Schauer asks:

Can a decisionmaker distinguish those state interests that are "compelling" from those that are "important" from those that are merely "rational"? Can a decisionmaker distinguish "proof beyond a reasonable doubt" from "clear and convincing evidence" from "a preponderance of the evidence"? Can decisionmakers distinguish "de novo" review from 
place such matters in the hands of judges with the hope that they will carry out their adjudicative duties conscientiously and in a manner worthy of the public's respect. Rather, I intend these analytic tools to help a federal court determine the likelihood that a state court's application of law to fact should be deemed objectively unreasonable, even if we are not yet able to describe the specific hallmarks of unreasonable applications of law to fact in all cases. In other words, the analytic touchstones I propose in this section are intended to enable federal courts to broaden still further the range of cases in which they are able to conduct a principled analysis, notwithstanding their inability to draw a precise line separating reasonable and unreasonable rulings in every case that comes before them.

\section{A. Is the Applicable Legal Directive More Like a Rule or a Standard?}

Federal constitutional law is rife with rules and standards. ${ }^{287}$ Both rules and

review only for "abuse of discretion"? The question raised by all of these standards and others is the same: Can we admit the possibility of overriding some judgment while at the same time not opening the door to unconstrained substitution of judgment?

Schauer, supra note 216, at 545. Professor Schauer continues:

It is debatable whether some form of deferential but genuine review is possible. It might be argued that deferential but not toothless review is an illusion. Once the reviewing decisionmaker has the authority to look at the decision below with at least the possibility of overturning it, deference becomes largely illusory.

Id. Contrary to that suggestion, however, a number of federal habeas courts have already indicated that they believe state courts may have erred, but that they did not err unreasonably. See, e.g., Jones v. Stinson, 229 F.3d 112, 121 (2d Cir. 2000); Van Tran v. Lindsey, 212 F.3d 1143, 1158 (9th Cir.), cert. denied, 121 S. Ct. 340 (2000).

${ }^{287}$ See Aleinikoff, supra note 277 , at $943-44$ (stating that the use of standards, or balancing tests, in constitutional adjudication has "become widespread, if not dominant, over the last four decades"); Chen, supra note 90, at 579 (stating that "in the modern era of constitutional doctrine the Court articulates most constitutional rights as 'balancing tests,' or open-ended 'standards'"); Kathleen M. Sullivan, Post-Liberal Judging: The Roles of Categorization and Balancing, 63 U. CoLO. L. REV. 293, 294 (1992) [hereinafter Sullivan, Post-Liberal Judging] (stating that rules and balancing-test standards "have competed endlessly in contemporary constitutional law"). As both Aleinikoff and Sullivan demonstrate throughout the articles just cited, rules are often called "categorizations," while standards are often expressed in the form of "balancing" tests. One writer explains:

In constitutional law discourse, this distinction [between rules and standards] is often framed as the difference between categorization and balancing. When a court uses a categorization technique, it simply determines whether a particular state action infringes upon a clearly defined right; if it does, the law is unconstitutional regardless of the strength of the state's interest. On the other hand, when a court employs a balancing technique, it weighs the various interests and rights at stake against each other to determine the constitutionality of the state's action. 
standards are intended to serve the law's objectives, but they do so by different means. The primary differences between rules and standards have been well documented by others ${ }^{288}$ and are, briefly, as follows.

Rules seek to minimize judicial discretion by requiring particular outcomes when judges are presented with particular kinds of facts. ${ }^{289}$ When the rule's framers have clearly articulated the kinds of factual circumstances they intend the rule to govern, and when they have clearly identified the legal significance of those facts, the judge's job is fairly straightforward, even if not entirely mechanical: She must determine whether events triggering the rule's application have transpired. ${ }^{290}$ Rules may thus provide both private and public actors with a measure of certainty, insofar as they enable one to predict with considerable accuracy the legal consequences of particular kinds of conduct. ${ }^{291}$ This perceived certainty, however, comes at a cost. Because of their rigidity, rules will sometimes seem to dictate outcomes that are at odds with the purposes those rules are intended to serve. Banning the sale of alcohol to persons under the age of twentyone, for example, serves the rule's intended purpose of keeping alcohol out of the hands of many persons who lack the maturity to drink it responsibly. Yet the rule also fails to account for irresponsible adults and exceptionally responsible youths. $^{292}$

Standards, on the other hand, purport to provide judges with discretion to determine the legal significance of facts by taking into account overarching values, principles, or policies. ${ }^{293}$ When applying a standard, a judge must do more

Jay D. Wexler, Defending the Middle Way: Intermediate Scrutiny as Judicial Minimalism, 66 GEO. WASH. L. REV. 298, 299 (1998); see also Kathleen M. Sullivan, Foreword: The Justices of Rules and Standards, 106 HARV. L. REV. 24, 59 (1992) [hereinafter Sullivan, Foreword] ("Categorization corresponds to rules, balancing to standards."). While recognizing that different people sometimes mean different things when they use the terms "rules," "standards," "principles," and "policies," see Sullivan, Foreword, supra, at 58 n.231, I use those terms here in the familiar way described above in the main text.

${ }^{288}$ For useful introductions to the nature of rules and standards, see Duncan Kennedy, Form and Substance in Private Law Adjudication, 89 HARV. L. REV. 1685, 1687-94 (1976); Pierre Schlag, Rules and Standards, 33 UCLA L. REV. 379, 383-89 (1985); and Sullivan, Foreword, supra note 287, at 62-69.

${ }^{289}$ See Sullivan, Foreword, supra note 287, at 58.

${ }^{290}$ See HART \& SACKS, supra note 249, at 155-56; Kennedy, supra note 288, at 1687-88 (stating that a clearly articulated rule is characterized by "formal realizability," in the sense that it provides "a directive to an official that requires him to respond to the presence together of each of a list of easily distinguishable factual aspects of a situation by intervening in a determinate way").

${ }^{291}$ See Kennedy, supra note 288, at 1688-89.

${ }^{292} \mathrm{Cf}$. id. at 1689 (using age restrictions as an example of over- and under-inclusive rules).

${ }^{293}$ See Sullivan, Foreword, supra note 287, at 58-59. The differences between rules and standards should not be over-emphasized. Not only do those forms of legal directives exist along a continuum, but the notion that paradigmatic rules put an end to judges' legal reasoning 
than find the pertinent facts and identify the applicable legal directives; she must also assess those facts against the backdrop of the law's objectives, ${ }^{294}$ such as ensuring that police officers stay within the bounds of reasonable conduct. A legal directive that instructs a judge to consider the "totality of the circumstances" is a paradigmatic standard. ${ }^{295}$ While a standard permits a judge to try to ensure that the outcome of an adjudication is consistent with the law's objectives, ${ }^{296}$ it does so at the expense of those private and public actors who wish to predict the legal consequences of particular actions. ${ }^{297}$ The more one moves toward the standards end of the rules-standards spectrum, the more general the legal directives' language becomes and the broader the range of outcomes that those legal directives may reasonably be construed to permit. ${ }^{298}$

on a given matter is often (if not always) inaccurate. First, rarely are lawmakers able to frame a rule that describes with perfect specificity the factual circumstances they intend the rule to encompass. When a rule's scope and terms are even slightly ambiguous, it can be difficult to say that a single outcome is indisputably dictated by that rule. See supra notes 229-31 and accompanying text (discussing the indeterminacy debate). But cf. supra notes 68-71 and accompanying text (describing the Teague analysis, which asks whether extant law "dictated" a particular result at the time a habeas applicant's conviction became final). Second, if a court encounters a case in which a rule appears to dictate an outcome that is at odds with the objectives the rule is intended to serve, the court might amend the rule (if it is judge-made) or find some other way to refrain from enforcing it. To some extent, therefore, courts often expressly or implicitly balance competing interests and judge the fit between legal directives and legal objectives, regardless of whether the extant law seeks to achieve those objectives by prescribing rules or standards. See Aleinikoff, supra note 277, at 979-81.

${ }^{294}$ See HART \& SACKS, supra note 249, at 157; Kennedy, supra note 288, at 1688.

${ }^{295}$ See Sullivan, Foreword, supra note 287, at 59. Justice Scalia has argued that "totality of the circumstances" tests are illegitimate. See Scalia, supra note 222, at 1180-81 ("[W] appellate judge comes up with nothing better than a totality of the circumstances test to explain his decision, he is not so much pronouncing the law in the normal sense as engaging in the less exalted function of fact-finding."); id. at 1182 (arguing that adopting such tests is "a regrettable concession of defeat-an acknowledgment that we have passed the point where 'law,' properly speaking, has any further application").

${ }^{296}$ See HART \& SACKS, supra note 249, at 157 (stating that, by postponing a policy judgment about a particular factual situation until adjudication, using a standard avoids 'the imprisonment of general judgment in any precise verbal formula").

${ }^{297}$ See Sullivan, Foreword, supra note 287, at 58-59. Once courts believe they have encountered the range of factual circumstances to which a particular standard is likely to apply, and that the need for doctrinal flexibility is thus no longer as great as it once was, they may provide citizens and judges alike with greater certainty by moving toward the rules end of the continuum and articulating the law's requirements with greater specificity. See HART \& SACKS, supra note 249, at 158; Aleinikoff, supra note 277, at 979.

${ }^{298}$ As Henry Hart and Albert Sacks explained, if law were always stated in the form of perfectly precise rules,

the function of law application would be an almost mechanical one hardly worthy of separate notice. But all law is not stated that way. To the extent that the law formulated by 
Examples of rules and standards may be found throughout the Court's constitutional jurisprudence relating to criminal suspects and defendants. As Alexander Aleinikoff has observed concerning the Fourth Amendment, for example, standards now play leading roles in determining whether a search or seizure has occurred, whether a search or seizure was reasonable, whether an officer had probable cause to arrest, whether an officer had sufficient cause to justify an investigative stop, and whether a warrant was required for a search. ${ }^{299}$ Other examples abound. In Jackson v. Virginia, ${ }^{300}$ the Court adopted a broadly framed standard for reviewing insufficiency-of-the-evidence claims. ${ }^{301}$ In contrast, Miranda $v$. Arizona $a^{302}$ issued a directive that (at least facially) is more in the nature of a rule: a prosecutor may not introduce any evidence "stemming from custodial interrogation of the defendant unless it demonstrates the use of procedural safeguards effective to secure the privilege against selfincrimination. ${ }^{, 303}$

The rules-standards distinction clearly can play a role in federal courts' application of $\S 2254(\mathrm{~d})$. The more the governing legal directive appears in the form of a standard, the wider the range of outcomes that may reasonably be deemed permitted by that directive; the more the directive resembles a rule, the

the judge in general terms leaves open other questions than the identification, simply, of what happened in the particular situation presented, the application of law will necessarily involve judgment. Obviously, the more imprecise the general formulation, the more uncontrolled the judgment will be.

HART \& SACKS, supra note 249, at 375.

${ }^{299}$ See Aleinikoff, supra note 277 , at 965 ; see also Tennessee v. Garner, 471 U.S. 1, 8 (1985) ("[T]he balancing of competing interests [is] the key principle of the Fourth Amendment.") (internal quotation omitted).

300443 U.S. 307 (1979).

${ }^{301}$ See id. at 319 (holding that a criminal defendant's due process rights are violated if he is convicted notwithstanding the fact that, "viewing the evidence in the light most favorable to the prosecution," no reasonable juror "could have found the essential elements of the crime beyond a reasonable doubt").

${ }^{302} 384$ U.S. 436 (1966).

${ }^{303}$ Id. at 444. Reflecting the manner in which multiple rules and standards may bear upon a single legal dispute, however, the Court has declined to adopt bright-line rules for use in determining whether a person was "interrogated" for Miranda purposes. See Rhode Island v. Innis, 446 U.S. 291, 301 (1980) ("A practice that the police should know is reasonably likely to evoke an incriminating response from a suspect ... amounts to interrogation."). The Court has likewise declined to adopt bright-line rules for use in determining whether a person was in "custody" for Miranda purposes. See Berkemer v. McCarty, 468 U.S. 420, 437 (1984) (stating that, in each case, the court must determine whether the circumstances exerted "pressures that sufficiently impair [the suspect's] free exercise of his privilege against self-incrimination"); see also id. at 441 (conceding that resisting adoption of a bright-line rule "will mean that the police and lower courts will continue occasionally to have difficulty deciding exactly when a suspect has been taken into custody"). 
narrower the range of outcomes that it may reasonably be interpreted to permit. Roughly ascertaining the relevant legal directive's place on the rules-standards spectrum, therefore, will help a federal court to ascertain the likelihood that a ruling contrary to the one it would reach on de novo review should nevertheless be deemed reasonable. Justice Kennedy acknowledged the diversity of outcomes a broadly framed legal directive may reasonably be interpreted to permit when he described Teague's new-rule jurisprudence in his concurring opinion in West:

Teague does bear on applications of law to fact which result in the announcement of a new rule .... If the rule in question is one which of necessity requires a case-by-case examination of the evidence, then we can tolerate a number of specific applications without saying that those applications themselves create a new rule. The rule of Jackson $v$. Virginia... is an example. ${ }^{304}$

Similarly, with respect to state courts' erroneous rulings on mixed questions of law and fact, the more general the terms appearing in the governing legal directive, as construed in the controlling Supreme Court precedent, the broader the range of outcomes a state court may reasonably interpret that legal directive to permit, and the greater the likelihood that the state court's ruling should be left undisturbed. ${ }^{305}$

\section{B. Was the Applicant's Claim Deemed Meritorious by a Lower State} Tribunal That Was Best Positioned to Resolve the Issue?

Miller v. Fenton's functional analysis for distinguishing between questions of fact and mixed questions of law and fact suggests that the judicial actor best

${ }^{304}$ Wright v. West, 505 U.S. 277, 308 (1992) (Kennedy, J., concurring in the judgment); see supra notes 77-86 and accompanying text (discussing the Justices' competing opinions in West). The meaning of the word "rule" in Justice Kennedy's second and third quoted sentences appears synonymous with what I and others have called a "standard." The difference in terminology is inconsequential; Justice Kennedy was simply speaking the "new rule" language of Teague.

${ }^{303}$ The United States Court of Appeals for the Second Circuit recently implicitly endorsed this form of analysis in a case conceming the application of the Supreme Court's broadly framed standards concerning custodial interrogations and the Fourth Amendment:

The difficulty of determining "custody" for purposes of Miranda and the Supreme Court's lack of clear guidance on the issue in the context of [facts comparable to those presented in this case] suggest that, unless the facts clearly establish custody, a state court should be deemed to have made a reasonable application of clearly established Supreme Court law in concluding that custody for Miranda purposes was not shown.

Cruz v. Miller, 255 F.3d 77, 85-86 (2d Cir. 2001) (internal citation omitted); see supra note 303 (discussing the broad directives governing "custody" determinations). 
positioned to resolve a given question should be given primary responsibility for resolving it. ${ }^{306}$ Prior to AEDPA's enactment, for example, the federal courts labeled a question as a question of fact-even if resolving the question required the application of a legal directive - if the question turned principally on an assessment of witnesses' demeanor and credibility, because (1) trial courts were best positioned to make those assessments and (2) questions of fact-unlike mixed questions - were reviewed by federal habeas courts under a deferential standard. ${ }^{307}$ AEDPA largely eviscerates the vitality of Miller's functional analysis by prescribing a deferential standard of review for both mixed questions and pure questions of fact. ${ }^{308}$ A variation of Miller's analytic framework may nevertheless still play an important role under AEDPA.

Miller's analysis is binary: It assumes that a question (other than a pure question of law) must be labeled either as a question of fact or as a mixed question of law and fact. Applying that analysis prior to 1996, the federal courts concluded that most of the claims they routinely address were not claims that the state courts were best positioned to resolve and so no deference was owed to the state courts' rulings on those claims. ${ }^{309}$ Although Miller's binary analysis is undercut by AEDPA's adoption of a deferential standard of review for mixed questions, it remains possible to place a mixed question-as it arises in a particular case-on a spectrum representing the varying degrees to which the adjudication of a claim rests upon assessments best made by a court with firsthand exposure to the relevant testimony and the trial process. In a particular case, for example, the determination of whether a defendant voluntarily confessed might turn to a large extent on an evaluation of witnesses' demeanor and credibility, while the determination of whether a prosecutor was required to disclose potentially exculpatory evidence to a defendant might turn on issues resolved as easily by an appellate court as by a trial court-even though, prior to AEDPA, the state courts were not generally deemed better situated to make those determinations and so federal courts resolved both issues de novo. ${ }^{310}$

A two-step analysis is therefore appropriate when a federal court is applying the "unreasonably erroneous" standard. First, the federal court should determine

${ }^{306}$ See Miller v. Fenton, 474 U.S. 104, 113-14 (1985) (explaining the functional analysis); supra notes 36-40 and accompanying text (discussing Miller).

${ }^{307}$ See supra note 39 and accompanying text.

${ }^{308}$ See supra note 53 and accompanying text.

309 See supra notes 41-52 and accompanying text.

${ }^{310}$ See supra notes $41-52$ and accompanying text. When the relevant evidence was introduced in documentary form, for example - such as in the form of affidavits or expert reports - the trial and appellate courts are comparably well-positioned to evaluate that evidence. When the relevant evidence was introduced in the form of live testimony, on the other hand, trial courts ordinarily are better positioned than appellate courts to resolve disputes concerning credibility. 
whether the state court that first received the relevant evidence and observed the adjudicatory process—often the state trial court-ruled in favor of the applicant on the federal claim at issue, notwithstanding a subsequent reversal by a state appellate court. Second, if the evidence-taking state court ruled in favor of the applicant on the claim in question, the federal court should ascertain the extent to which the proper disposition of that claim, in that particular case, turns on a live assessment of the testimony and on direct observations of the trial process. The greater the degree to which resolution of the claim turns on such live assessments and direct observations, the more likely it is that a ruling contrary to the one made by the judge who made those assessments and observations is unreasonable. Miller's categorical classification of federal constitutional claims, as either best resolved or not best resolved by state courts, is not appropriate here. Rather, a federal habeas court should make a case-specific determination of the issues on which the merits of the applicant's claim turn. In one case, an applicant's ineffective-assistance-of-counsel claim might rest heavily upon matters best evaluated by a judge with first-hand exposure to the trial process, for example, while the merits of another applicant's ineffective-assistance-of-counsel claim might rest upon matters that the appellate court is just as well suited to evaluate as the trial court.

Two different scenarios may arise, therefore, in cases in which live assessments and direct observations do play an important role in the legal analysis and in which the federal habeas court would grant relief if it were reviewing the claim de novo. If the state court that took the relevant evidence concluded that the claim was meritorious, then there is a greater likelihood that a state appellate court's rejection of that claim - namely, the state court adjudication under review pursuant to $\S 2254$ (d) - should be deemed unreasonable. If instead the state court that took the relevant evidence ruled against the applicant and the state appellate court simply affirmed, then there is a greater likelihood that the state court ruling under review should be deemed reasonable, even if contrary to the federal court's own assessment of the claim's merits. ${ }^{311}$

Williams illustrates the point. The merits of Williams's claim turned primarily on a court's determination of the likelihood that a particular jury would have

${ }^{311}$ At no point in this analysis need a federal court determine whether the state courts' factual findings were correct. Section 2254(d)(2) authorizes federal habeas relief if the state court's rejection of the applicant's claim rested upon an unreasonable determination of the historical facts. See 28 U.S.C. § 2254(d)(2) (Supp. II 1996); see also id. § 2254(e)(1) (stating that a state court's factual findings must be accepted as correct unless the habeas applicant rebuts the presumption of correctness by "clear and convincing evidence"). When the success of an application turns on $\$ 2254(\mathrm{~d})(1)$ 's "unreasonable application" clause, therefore, the presumption is that the state court's factual findings are correct. What remains to be determined is whether the state court acted reasonably when it determined that those facts are not sufficient to establish that the applicant's claim is meritorious. 
recommended a non-capital verdict if it had heard certain items of mitigating evidence. The trial court, which was well-positioned both to evaluate the persuasive power of the evidence that was admitted and to observe the jury before which that evidence was introduced, concluded that there was a reasonable probability that the jury would not have recommended a death sentence if it had heard the additional mitigating evidence. ${ }^{312}$ The Virginia Supreme Court, however, reversed. ${ }^{313}$ On the analysis just proposed, one would conclude that, because the Virginia Supreme Court rejected the findings of a court better positioned to address the merits of Williams's claim, it was more likely than it would otherwise be that the Virginia Supreme Court's ruling was unreasonable. The United States Supreme Court did indeed reject the Virginia Supreme Court's analysis, apparently in part on the strength of reasoning such as that just proposed:

After hearing the additional evidence developed in the postconviction proceedings, the very judge who presided at Williams' trial, and who once determined that the death penalty was "just" and "appropriate," concluded that there existed "a reasonable probability that the result of the sentencing phase would have been different, if the jury had heard that evidence."

When one state court was best positioned to resolve a claim and found that claim meritorious, therefore, a higher state court's subsequent rejection of that claim should be examined with a heightened measure of skepticism. ${ }^{315}$

${ }^{312}$ See Williams v. Taylor, 529 U.S. 362, 370-71 (2000).

${ }^{313}$ See id. at 371 .

${ }^{314}$ Id. at $396-97$ (emphasis added) (quoting the trial court's ruling, as printed in the appellate record). During oral argument, one Justice addressed the issue even more directly:

The very judge who sat on the trial, when presented with this mitigating evidence that was not presented at trial, said ... that at least one and perhaps all of the jurors would have been affected by this. Now, trial judges generally have a better feeling for jurors and their reaction. Does that factor into this at all, or must we just shut from our sight that the very judge who conducted this trial thought that there was a reasonable probability that the result would have been different?

Transcript of Oral Argument at 38, Williams v. Taylor, 529 U.S. 362 (2000) (No. 98-8384). Even the three dissenting Justices conceded that the prejudice inquiry in an ineffectiveassistance-of-counsel claim is often "heavily factbound." See Williams, 529 U.S. at 419 (Rehnquist, C.J., concurring in part and dissenting in part).

${ }^{313}$ In Ramdass, the legal issues had very little relation to firsthand evidentiary observations; indeed, on the post-Simmons remand, the Virginia Supreme Court was the only state court to examine the merits of the applicant's claim. See Ramdass v. Angelone, 530 U.S. $156,163-64$ (2000); supra note 125 and accompanying text. Ramdass's claim tumed largely on the legal significance of the fact that a defendant might be accorded some form of postconviction relief with respect to a crime of which he had been convicted, but for which final judgment had not yet been entered. A first-hand evaluation of evidence does not play an important role in resolving that claim. 


\section{Does the Federal Court Believe That the Applicant Proved His or Her Claim by a Narrow or a Wide Margin?}

A federal court that believes a habeas applicant's claim is meritorious may believe that the applicant satisfied her burden of proof by a narrow or a wide margin. ${ }^{316}$ The narrower the margin by which a federal court believes an applicant has proved her claim, the more likely it is that reasonable minds could differ on the claim's merits, and so the more likely it is that the state court's rejection of the claim was reasonable. Conversely, the more overwhelming a federal court finds an applicant's arguments and evidentiary showing, the less likely it is that the state court's rejection of the applicant's claim was reasonable. ${ }^{317}$ Several courts have already employed such reasoning in their efforts to apply $\S 2254(\mathrm{~d}) .^{318}$ While this line of reasoning does contain a subjective element-namely, the federal habeas court's own assessment of the margin by which an applicant satisfied her burden of proof - it does not rest on the sort of subjectivism rejected in Williams. ${ }^{319}$ Rather, it uses the federal court's assessment of the strength of the applicant's case as a means of determining the likelihood that judges could reach conflicting conclusions concerning the merits of the applicant's claim.

\footnotetext{
${ }^{316}$ See supra note 278 and accompanying text (discussing habeas applicants' burden of proof).

${ }^{317}$ This analytic touchstone is similar to, but distinct from, the "firm conviction" analysis
} prescribed by the "clearly emroneous" standard of review. See supra notes 141-65 and accompanying text (distinguishing the "unreasonably emoneous" and "clearly erroneous" standards). A federal court could be firmly convinced that the applicant has proved her claim, while still conceding that she had not proved it by much. See Francis S. v. Stone, 221 F.3d 100, 110 (2d Cir. 2000) ("[A] habeas court will likely be firmly convinced of its conclusion whenever a state court has committed a mistake more egregious than error, but it might also be firmly convinced that just an ordinary error has occurred."). If a federal court is indeed "firmly convinced that just an ordinary error has occurred," see id., it might still conclude that the outcome is one about which reasonable minds could differ.

${ }^{318}$ Compare Tucker v. Catoe, 221 F.3d 600, 614-15 (4th Cir.) (holding that, while the state court's rejection of a claim was "incorrect," it is "a close issue" and so the state court's contrary conclusion was not objectively unreasonable), cert. denied, 531 U.S. 1054 (2000), and Francis $S$., 221 F.3d at 110-11 (noting Tucker and stating that "[s]ome increment of incorrectness beyond error is required," though "the increment need not be great," and rejecting the applicant's claim because the issue was "close"), with Washington v. Smith, 219 F.3d 620, 630 (7th Cir. 2000) (holding that the performance by the applicant's trial counsel fell "so wide of the mark, that we are left with the conviction that the [state court] decision to the contrary was an unreasonable application of Strickland's performance standard").

${ }^{319}$ See supra notes 106-10 and accompanying text (discussing Williams's rejection of the notion that a ruling is necessarily reasonable if it was endorsed by at least one reasonable judge). 


\section{CONCLUSION}

Determining how $\S 2254(d)$ 's "unreasonably erroneous" standard can be applied in a principled manner raises questions that cut to the heart of the adjudicative function. How do courts determine what the law requires? What constrains judges' interpretations of legal texts? What should judges do when the law's underlying purposes pull in opposing directions? How do we define the boundaries of legitimate disagreement when debating the law's demands? While conventionalism provides assistance in many cases, the federal courts do not yet have the theoretical framework necessary to answer those questions in all cases. Federal habeas courts are not left entirely at sea in the absence of a satisfactory theory of adjudication - there are a variety of analytic touchstones to which a federal habeas court can refer in order to acquire at least some measure of guidance. But for those who wish to maximize the intellectual integrity of judicial decision making in all cases-particularly when persons' lives and liberty are directly at stake, as they are in federal habeas proceedings-much work remains to be done. 